\title{
How Has Labor Demand Been Affected by the COVID-19 Pandemic? Evidence from Job Ads in Mexico*
}

Raymundo M. Campos-Vazquez ${ }^{1}$, Gerardo Esquivel ${ }^{2}$, Raquel Y. Badillo ${ }^{3}$
* We are grateful for research assistance from Alejandro Uribe. The content of this study does not necessarily reflect the official opinion of the Banco de Mexico or its Board. Responsibility for the information, errors, omissions, and views expressed lies entirely with the authors. Declaration of interests: none.

1 Corresponding author: Banco de México. Av. 5 de Mayo 2, Col. Centro, 06000 Mexico City. Tel.: +52 555237 2258. The author is on academic leave at Banco de Mexico. He is a Professor at El Colegio de Mexico, Carretera Picacho-Ajusco 20, Col. Ampliación Fuentes del Pedregal 14110 https://cee.colmex.mx/raymundo-campos. Email: rmcampos@,colmex.mx.

2 Banco de México. Av. 5 de Mayo 2, Col. Centro, 06000 Mexico City. Tel.: +52 5552372258. Email: gerardo.esquivel@,banxico.org.mx.

3 Banco de México. Av. 5 de Mayo 2, Col. Centro, 06000 Mexico City. Tel.: +52 5552372258. Email: rbadillos@banxico.org.mx.

\begin{abstract}
There is a concern among social scientists and policymakers that the COVID-19 crisis might permanently change the nature of work. We study how labor demand in Mexico has been affected during the pandemic by web scraping job ads from a leading job search website. As in the U.S., the number of vacancies in Mexico declined sharply during the lockdown (38 percent). In April there was a change in the composition of labor demand, and wages dropped across the board. By May, however, the wage distribution and the distribution of job ads by occupation returned to their pre-pandemic levels. Overall, there was a slight decline in specific requirements (gender and age), no change in required experience, and a temporary increase in demand for low-skilled workers. Contrary to expectations, opportunities for telecommuting diminished during the pandemic. Using a simple Oaxaca-Blinder decomposition, we find that the variation in the average advertised wage in April is explained more by a higher proportion of low-wage occupations than by a reduction in the wages paid for particular occupations. In sum, we find no evidence of a significant or permanent change in labor demand during the pandemic in Mexico.
\end{abstract}

Keywords: Job ads; Labor demand; Employment; Wages; COVID-19; Mexico.

JEL: J20; J23; J30; J60; O54. 


\section{Introduction}

GOVID-19 has substantially affected the economy in a very short period. Labor markets have been disrupted to an unprecedented extent. More than 20 million jobs were lost in the United States just in April 2020, a tripling of the unemployment rate in that month. In Mexico, the economically active population lost 12 million workers between March and April 2020, a decline of 21 percent. These dramatic changes may have effects on the labor market that are yet to be understood, especially on the behavior of potential employers, and there is a valid and growing concern about whether this shock will permanently affect the labor market. In this paper we analyze this question using data from job ads in Mexico before and during the pandemic.

It is possible that social distancing measures might permanently change the nature of work through a reallocation of jobs and changes in occupational structures (Baldwin, 2020). Delivery-oriented firms and essential sectors are growing, whereas sectors considered non-essential, such as tourism and transportation, are shrinking (Barrero, Bloom, \& Davis, 2020). The future of work may be based on maintaining social distance, and it may depend on technology to communicate with and evaluate employees (Stahl, 2020). However, some authors have found that workers expect current work patterns to prevail (Von Gaudecker et al. 2020). It is therefore of the utmost importance to determine whether this crisis will cause a permanent adjustment to labor demand.

Traditional household surveys and administrative data provide ample information on workers' characteristics that can help us understand the effects of the crisis on labor supply. However, there is relatively little information about its effects on labor demand. Specifically, we know little about what types of jobs are still available or what new jobs are most in demand.

An important source of data regarding labor demand is online job search websites. Web scraping and data science techniques make it possible to analyze the information included in these sites: types of vacancies, wages offered, job characteristics, and qualifications sought can be extracted and disentangled with the use of text analysis. Previous studies have analyzed the job search process (Faberman \& Kudlyak, 2016) and the matching process between job seekers and vacancies (Choi, Banfi, \& Villena-Roldan, 2019; Kuhn \& Shen, 2013a; Marinescu \& Rathelot, 2018). Others have focused on labor demand and hiring preferences, including the demand for specific skills and characteristics (Kuhn \& Shen, 2015). There have also been studies focused on wages, which have found that the specification of compensation is strategic (Brenčič, 2012), and that wages are related to the wording used in job titles (Marinescu \& Wolthoff, 2020). Other studies have analyzed how ads incorporate stereotypes of gender (Arceo-Gómez, Campos-Vázquez, Badillo-Salas, \& López-Araiza, 2020) and have revealed the preferences of employers according to the characteristics of the job ads posted (Chowdhury et al. 2018; Kuhn \& Shen, 2013b).

Online job boards have also allowed us to understand the labor market during crisis periods. Brown and Matsa (2016) study the matching process between job seekers and vacancies during the Great Recession in the U.S. They find that distressed firms attract fewer candidates and lower-quality applicants than non-distressed firms. Other studies focus on how skill requirements vary in times of economic crisis Hershbein \& Kahn, 2018; Modestino, Shoag, \& Ballance, 2019), and find that skill requirements such as minimum education or experience increase when economic conditions worsen.

Forsythe, Kahn, Lange, and Wiczer (2020) analyze job search websites during the COVID crisis in the U.S. They have two key findings. First, job websites replicated the timing of unemployment insurance claims during the early stages of the GOVID crisis, meaning that the information they contain is relevant at the macroeconomic level. Second, they find that employment vacancies declined by 30 percent in March 2020, and that all types of vacancies were 
affected, regardless of industry or occupation. For live tracking of the evolution of job postings, see Chetty et al. (2020).

Our paper contributes to this literature in several ways. First, there is scant evidence on how labor demand adjusts to a crisis in a developing country. ${ }^{1}$ Second, the crisis of the Great Confinement differs from that of the Great Recession. There is currently a debate about whether this crisis might permanently change the nature of work and labor demand, for example by favoring occupations with more options for telecommuting instead of face-to-face interaction. We provide some evidence against this possibility, at least in the early stages of the crisis. Third, we analyze the wage and occupational distribution of new job postings, as this distribution provides further evidence of possible changes in the labor market.

The COVID-19 pandemic has severely affected the labor market in Mexico in a very short time, mostly because of the measures to contain the virus. The first case in Mexico was diagnosed in late February. On March 14, the government suspended non-essential activities and rescheduled large public events. On March 23, the government announced a voluntary lockdown. These measures had an immediate impact on the labor market: in the last two weeks of March, Mexico lost more than 346,800 formal employees, ${ }^{2}$ and the situation worsened in April, with a loss of more than 550,000 formal workers. The most affected sectors were personal services and construction, and more than 80 percent of those who lost their employment were in the lower part of the wage distribution (with earnings less than twice the minimum wage).

We obtained our data by web scraping the job ads from a leading job search website in Mexico. ${ }^{3}$ We downloaded ads daily, beginning in January 2020. The period we analyze here is from January to September 2020. A typical ad includes the job title, the state in which the job is located, compensation, and the text of the ad. Companies use the text to describe the educational and skill requirements of the job, as well as some demographic requirements (age or sex). In total, we analyzed 339,224 ads.

The main results are as follows. We are not able to identify a fundamental change in the nature of workers in demand, only a decrease in the number of available jobs, which is expected given the lower level of economic activity. As in the U.S., the number of vacancies declined sharply with the beginning of mobility restrictions: there was a decline of 38 percent in the number of job ads between February and May 2020. Although there was a recovery between June and September, the number of job ads in those months was still below the average number of job ads observed during the first two months of the year. In April there was a temporary increase in demand in low-wage occupations and a decrease in high-wage occupations. That month, wages also dropped across the board. However, by May they had returned to their pre-pandemic levels. Using a simple Oaxaca-Blinder decomposition, we find that the decline in the average wage offered in April was mainly due to a larger share of low-wage occupations, rather than a change in the wages offered in given occupations. Finally, one might have expected that companies would maintain or increase labor demand for telecommuting jobs, but the data clearly rejects that option. The decline in this type of vacancy was more than proportional: their share of the total number of job ads fell from 51 percent in January-February to an average of 43 percent during the third quarter of 2020. In sum, we do not find evidence of a permanent or significant change in the nature of work during this crisis in Mexico.

$1 \quad$ Although there is scant evidence on employment demand effects of COVID-19 in other Latin American countries, we can summarize some recent findings. First, the workers most affected are those in occupations with risk of automation or those that involve more face-to-face contact (Egaña, Cruz, and Micco, 2020; Al Masri, Flamini, and Toscani, 2020). Second, Komatsuzaki et al. (2020) show that informal workers are more likely to be employed in jobs with greater face-to-face contact and less with telecommuting. Third, Cardenas and Montana (2020) found that in Latin America, telecommuting requires a higher degree of education and this is correlated with higher salaries.

2 https://elpais.com/economia/2020-04-08/mexico-pierde-en-dos-semanas-el-empleo-creado-en-2019-en-un-ambiente-de-tension-entre-elgobierno-y-los-empresarios.html

3 For confidentiality reasons we do not reveal the website's name. However, it is among the top-5 job search websites in Mexico. See https:// onaliat.mx/blog/index.php/las-5-mejores-plataformas-buscar-trabajo/. 


\section{Dataset}

We construct the dataset using information from a leading Mexican online job search website. We web scrape the site daily from January to September 2020, for a total of 339,224 advertisements. The raw dataset contains the posting date, the job title, the description, the compensation offered, the location, and the economic sector of the hiring company. We also build other variables based on the textual description, including age, sex, education, and skills required. Finally, we classify the possibility of telecommuting, based on the work of Monroy-Gómez-Franco (2020).

To construct the wage variable, we use text analysis of the information in the ad; where a range is specified, we take the mean value. We manually classify the job description according to the SINCO 2011 sector and subsector classifications of the Mexican National Institute of Statistics and Geography (INEGI) and the Mexican Ministry of Labor and Social Welfare (STPS). The advantages of these classifications are that they were especially designed for the Mexican labor market, and that they can easily be translated to other international classifications, such as the ISCO-08. This last point is important in following the methodology of Monroy-Gómez-Franco (2020) to classify telecommuting availability.

Other variables are obtained from terms regularly used in the job descriptions. The main objective of these categories is to understand the requirements for the jobs advertised. We classify these variables into three categories: sociodemographic variables, variables related to qualifications and benefits, and pandemic-related variables. Sociodemographic variables are characteristics such as gender, age, location, marital status, and education. Variables related to qualifications and benefits are based on the inclusion of words such as commitment, punctual, honest, attentive, teamwork, helpful, courteous, control, initiative, motivation, pressure, proactive, responsible, enthusiasm, leadership, requests photograph, specifies appearance, English, common computer software, sales, customer, follow-up, availability, travel, driver's license, growth, development, training, bonus, benefits, and insurance. Finally, the last category of variables is based on the inclusion of words related to the COVID-19 pandemic, such as COVID, telecommuting, on-site work, distance, and health.

In sum, we have information at the monthly level on the number of ads with specific requirements for age, experience, schooling, and gender. We also record the wage and the occupation for each advertisement, as well as the words that are most frequently used in the text. We wish to analyze whether there is an abrupt change in the distribution of these statistics during the pandemic.

\section{Evolution and Distribution of Job Ads}

Figure 1 shows the number of job ads in the sample. Usually, the largest number of jobs are posted in January, advertisements decrease in February, and then they stabilize in subsequent months. From February to April there was a decline of 10 percent in the number of job ads, and from February to May the decline reached 38 percent. These reductions are larger than those found by Chetty et al. (2020) and Forsythe, Kahn, Lange, and Wiczer (2020) for the U.S. Although there is a recovery, the number of job ads in July was still 13 percent lower than in February. By August and September, there was an increase in the number of offers, but they are still below the January-February average. 
Figure 1. Number of jobs advertised by month, Jan.-September 2020

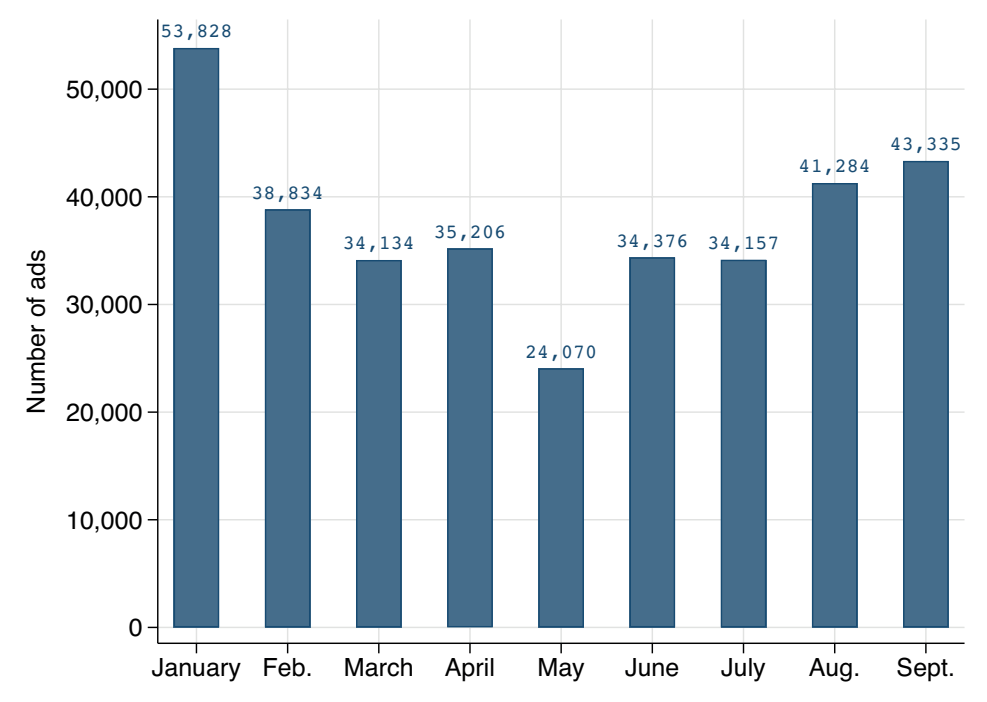

Note: Authors' calculations.

Figure 2 shows the distribution of job ads by occupation, codified at the one-digit level using the SINCO 2011 classification. Internet job searches in Mexico are biased toward higher-paying occupations. The 2019 Labor Force Survey indicates an average monthly wage of MXN $\$ 6,600$, while the average in the sample for January and February is MXN $\$ 13,445$. The occupational category with the highest demand (41 percent of the total ads in January-February) is professionals and technicians.

The figure shows the temporary shift in labor demand towards certain occupations. There is a pronounced spike in two occupations between January-February and April: merchants and sales personnel, and general laborers. Although voluntary confinement began in mid-March, there is no evidence of a clear shift in occupational targeting. Only during April does there appear to be a certain shift, but the distribution in June-September is very similar to that of January-February, except for an increase in the share of merchants and sales personnel, and small reductions in the demand for officers, directors, and managers, as well as for professionals and technicians.

Figure 3 shows changes in the frequency (relative to the total number of words) of the most common words in job titles. These 25 words represent 30 percent of the total number of words in job titles (not including stop words). The bars show the frequency of these words for each month, with the values for January-February shown on the right in brown and those for April in green. The figure shows that jobs related to sales, support, and account executives are in greatest demand. By April, there was a substantial increase in the frequency of job titles with the words support, salesperson, general (usually referring to general laborers), technician, helper, cashier, driver, security, physician, and operator. Many of these words returned to their January-February values by June-September, except for physician, technician, general, and helper, which remain slightly above their January-February levels.

Intuitively, based on Figure 3, it seems that there was a decline in demand in April for the best paid managerial and professional jobs, but increased demand for low-paid general labor, operations, and support jobs, and in general a return to the January-February levels from May through September. 
Figure 2. Distribution of job ads by occupation

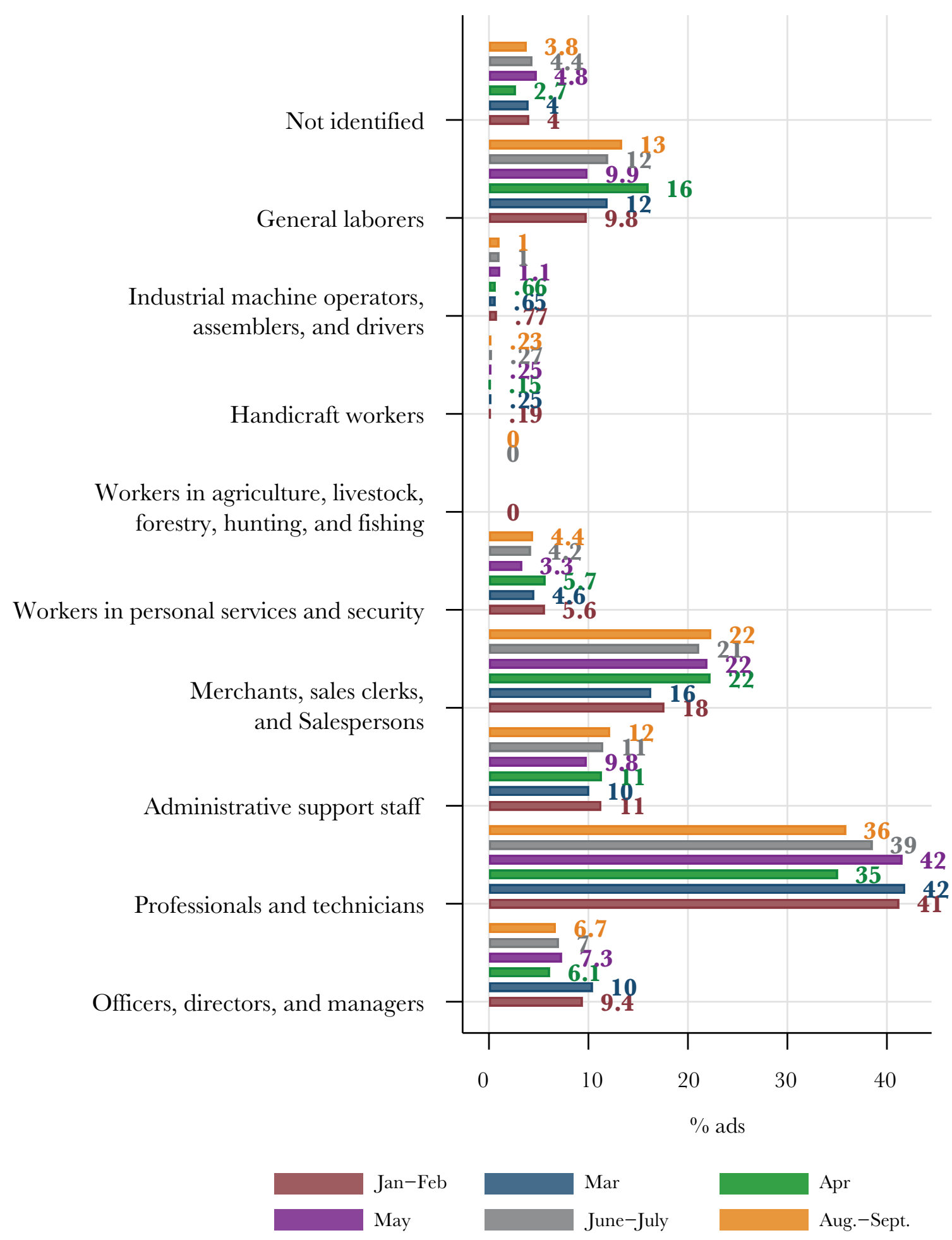

Notes: Authors' calculations. Occupations are defined by SINCO 2011 classification at the one-digit level: officers, directors, and managers (SINCO 2011=1); professionals and technicians (SINCO 2011=2); administrative support staff (SINCO $2011=3$ ); merchants, sales clerks, and salespersons (SINCO $2011=4$ ); workers in personal services and security (SINCO 2011=5); workers in agriculture, livestock, forestry, hunting, and fishing (SINCO 2011=6); handicraft workers (SINCO 2011=7); industrial machine operators, assemblers, and drivers (SINCO2011=8); and general laborers (SINCO 2011=9). 
Figure 3. Most repeated words in job titles

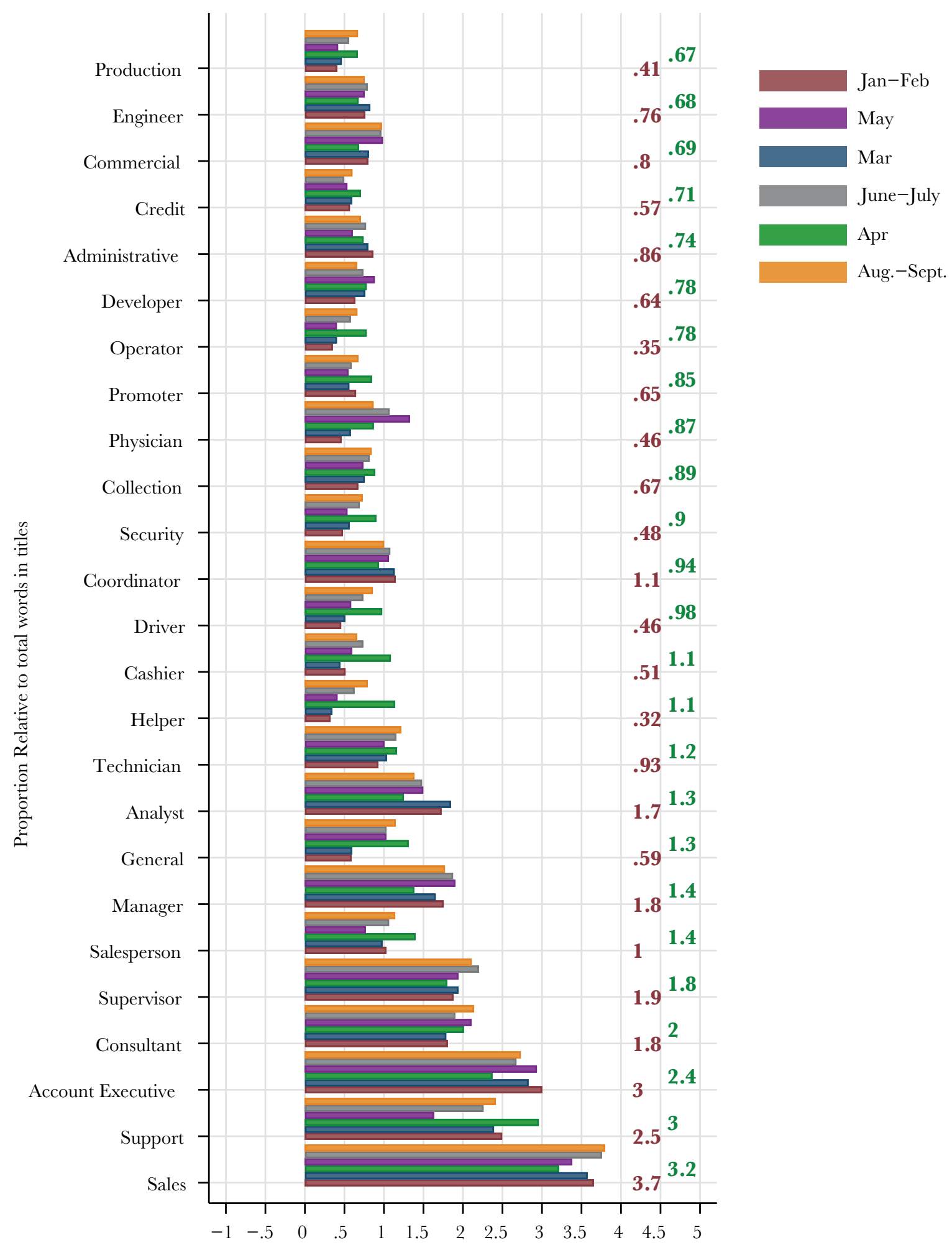

Notes: Authors' calculations. The table shows the most frequent words relative to the total number of words in job titles, omitting stop words. To calculate the proportions, we grouped together words with different endings for gender (e.g., vendedor/vendedora) and number (i.e., plural vs. singular). The figures on the right indicate the proportion in January-February (brown) and in April (green). 


\section{Ghange in Job Requirements During the Pandemic}

If labor demand is shifting rapidly, and there is a greater need to hire people, we might expect to see a decline in specific job requirements. Alternatively, if the labor market tightens, we might expect to see an increase in certain requirements, such as experience or education. We calculate the proportion of job ads that specify gender, age, experience, or educational requirements (Figure 4).

Figure 4. Proportion of job ads that include specific requirements

A. Gender

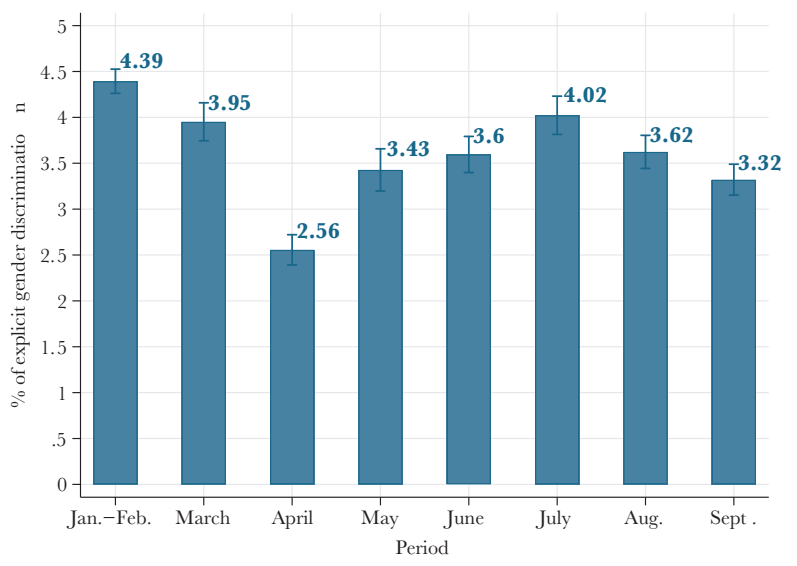

G. Experience

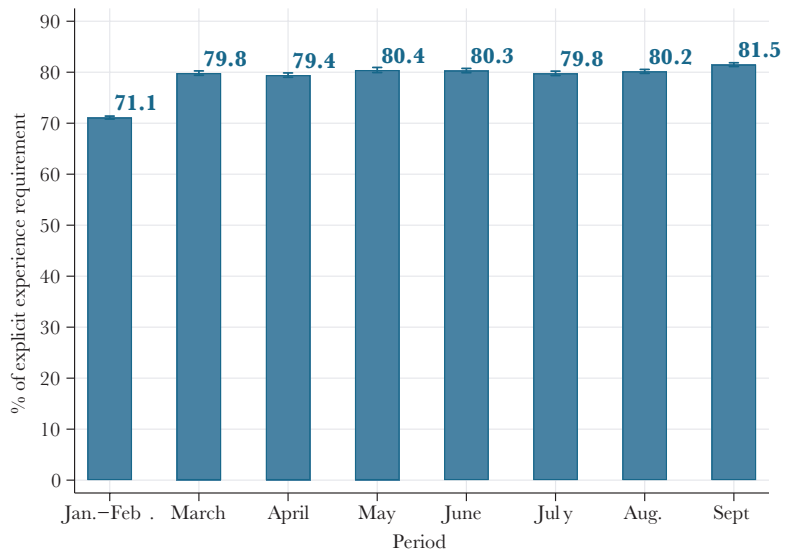

B. Age

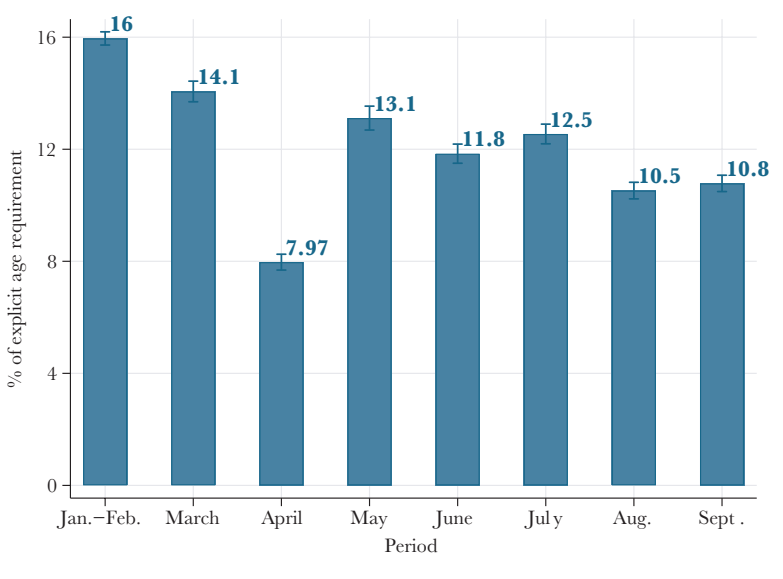

D. Education

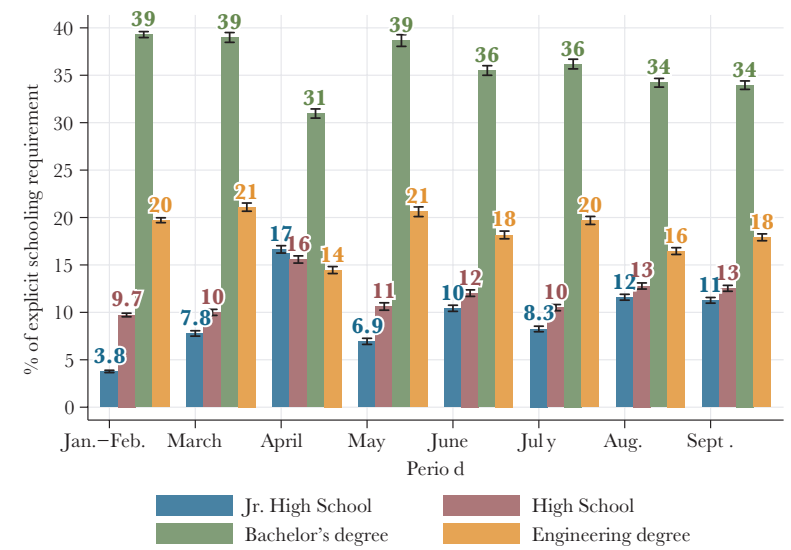

Notes: Authors' calculations. Range plot shows the CI at 95 percent.

Panel A shows that there was a temporary reduction in ads specifying gender. From January to March, about 4 percent of job ads specified a gender, but in April this proportion fell to 2.5 percent. However, by July it had already returned to 4 percent, with a small decrease in August and September. Panel B shows that there was a similar temporary decline in ads specifying age from March to April (from 14 to 8 percent), then a rebound from May to July (from 8 to approximately 12.5 percent), and a slight decrease in August and September. These two panels combined suggest that labor demand changed significantly during April but that it returned to normal very quickly. The only change in requirements that seems to be more lasting is an increase in the demand for experience, which increased in March and has remained higher than its pre-pandemic level (panel G). This result is consistent with previous findings about stricter labor demand requirements in the context of an economic crisis (Hershbein \& Kahn, 2018; Modestino, Shoag, \& Ballance, 2019). Finally, the proportion of ads specifying educational requirements (panel D) shifted slightly in April but rapidly returned to its previous level: requests 
for bachelor's and engineering degrees declined in April while those for junior high and high school diplomas increased.

To better understand the requirements for different jobs, we analyze the use of selected words referring to skills, applicant characteristics, and criteria that could be related to the pandemic. Table 1 shows the percentage of ads that contain a word at least once, for the full sample and for specific occupations such as professionals, merchants, sales personnel, and general laborers, the occupations that have shown the largest change in demand during the pandemic.

Interestingly, characteristics like teamwork and commitment were in greater demand in April. The proportion of ads specifying teamwork increased from 15 percent in January-February to 31 percent in April but returned to the former value in May; from June to September this specification increased again, to 23 percent. Ads specifying commitment increased from 5 percent in January-February to 13 percent in April; the proportion specifying this characteristic has remained higher than before the pandemic. Other requirements related to social interaction, such as being attentive, having a good appearance, including a photograph in the resume, and knowing English, fell during the first stage of the pandemic but soon returned to their previous levels, suggesting that there was no major shock for face-to-face jobs.

The specification of benefits also changed in April, with a decrease in ads using words such as training, base wage, and commission, but with an increase in the use of the word benefits. This could be related to the reduction in the average wage in April, with monetary or non-monetary benefits compensating for lower wages. However, since May these benefits-related words have slowly returned to their pre-pandemic levels.

Additionally, we explore some words related to the pandemic like work at home, on-site, health, digital, and COVID. Overall, we conclude that there are no large changes in the use of these words during the period studied. Using text analysis, we codify whether a job ad refers to work at home. There is an increase in the number of job ads using this term, particularly for professionals and technicians as well as for merchants, salesclerks, and salespersons, but the proportion of ads that use it is nonetheless relatively small ( 3 percent). There is also a small increase in the number of job ads using the term work on site. Thus, it seems that there has not been a substantial change in the option to work at home. 
Table 1. Specific Requirements in Job Posts by Occupation

\begin{tabular}{|c|c|c|c|c|c|c|c|c|c|c|c|c|c|c|c|c|}
\hline & \multicolumn{4}{|c|}{ All posts } & \multicolumn{4}{|c|}{ Professional and Technicians } & \multicolumn{4}{|c|}{ Merchants, Salesclerks \& Salespersons } & \multicolumn{4}{|c|}{ General Laborers } \\
\hline & Jan.-Feb. & April & May & June-Sept. & Jan.-Feb. & April & May & June- Sept. & Jan.-Feb. & April & May & $\begin{array}{l}\text { June- } \\
\text { Sept. }\end{array}$ & $\begin{array}{c}\text { Jan.- } \\
\text { Feb. }\end{array}$ & April & May & $\begin{array}{l}\text { June- } \\
\text { Sept. }\end{array}$ \\
\hline Observations & 92,662 & 35,206 & 24,070 & 153,152 & 38,205 & 12,347 & 9,998 & 56,795 & 16,333 & 7,834 & 5,283 & 33,384 & 9,093 & 5,640 & 2,384 & 19,499 \\
\hline Commitment & 5 & 13 & 6 & 9 & 4 & 9 & 5 & 7 & 4 & 16 & 7 & 10 & 8 & 19 & 8 & 16 \\
\hline Punctual & 6 & 6 & 5 & 6 & 6 & 5 & 5 & 6 & 6 & 6 & 5 & 6 & 6 & 9 & 5 & 8 \\
\hline Honest & 1 & 1 & 1 & 1 & 1 & 1 & 1 & 1 & 1 & 1 & 1 & 1 & 2 & 2 & 1 & 1 \\
\hline Attentive & 23 & 16 & 22 & 20 & 23 & 18 & 21 & 19 & 33 & 23 & 32 & 30 & 18 & 10 & 17 & 13 \\
\hline Teamwork & 15 & 31 & 16 & 23 & 14 & 25 & 15 & 21 & 11 & 31 & 14 & 21 & 18 & 42 & 22 & 34 \\
\hline Helpful & 0 & 0 & 0 & 0 & 0 & 0 & 0 & 0 & 0 & 0 & 0 & 0 & 0 & 0 & 0 & 0 \\
\hline Courteous & 1 & 0 & 1 & 1 & 1 & 0 & 0 & 1 & 0 & 0 & 0 & 1 & 1 & 0 & 1 & 0 \\
\hline Control & 18 & 16 & 20 & 19 & 21 & 19 & 22 & 23 & 9 & 9 & 11 & 10 & 12 & 7 & 12 & 11 \\
\hline Initiative & 3 & 2 & 3 & 3 & 3 & 2 & 3 & 3 & 3 & 2 & 2 & 3 & 2 & 1 & 2 & 2 \\
\hline Pressure & 9 & 5 & 8 & 7 & 10 & 6 & 9 & 9 & 7 & 4 & 7 & 6 & 7 & 3 & 6 & 5 \\
\hline Proactive & 8 & 5 & 8 & 7 & 8 & 5 & 7 & 7 & 8 & 6 & 10 & 8 & 5 & 2 & 5 & 4 \\
\hline Responsible & 11 & 8 & 12 & 10 & 11 & 8 & 11 & 11 & 10 & 7 & 12 & 9 & 10 & 6 & 12 & 8 \\
\hline Motivated & 0 & 0 & 0 & 0 & 0 & 0 & 0 & 0 & 1 & 1 & 1 & 1 & 0 & 0 & 0 & 0 \\
\hline Leadership & 7 & 9 & 8 & 9 & 7 & 10 & 7 & 9 & 7 & 8 & 8 & 9 & 6 & 7 & 7 & 7 \\
\hline Requests photograph & 4 & 2 & 3 & 3 & 3 & 2 & 3 & 3 & 5 & 2 & 3 & 4 & 2 & 1 & 2 & 1 \\
\hline $\begin{array}{l}\text { Specifies good ap- } \\
\text { pearance }\end{array}$ & 11 & 6 & 10 & 9 & 9 & 5 & 7 & 7 & 18 & 9 & 16 & 15 & 7 & 2 & 6 & 5 \\
\hline English & 18 & 12 & 18 & 15 & 25 & 20 & 25 & 22 & 11 & 5 & 9 & 7 & 7 & 2 & 7 & 5 \\
\hline $\begin{array}{l}\text { Common computer } \\
\text { software }\end{array}$ & 12 & 7 & 12 & 10 & 15 & 11 & 15 & 14 & 7 & 3 & 6 & 6 & 5 & 2 & 4 & 4 \\
\hline Sales & 34 & 29 & 34 & 33 & 22 & 18 & 18 & 19 & 78 & 61 & 77 & 73 & 40 & 25 & 38 & 31 \\
\hline Customer & 41 & 44 & 42 & 43 & 35 & 37 & 34 & 35 & 64 & 68 & 65 & 68 & 44 & 42 & 44 & 44 \\
\hline Follow-up & 20 & 14 & 19 & 18 & 19 & 15 & 18 & 19 & 26 & 15 & 22 & 23 & 17 & 10 & 17 & 13 \\
\hline
\end{tabular}

Note: Authors' calculations. See Table S1 for words in Spanish. Each row indicates the percentage of ads that include the word in the first column at least once. 
Table 1. (continuation) Specific Requirements in Job Posts by Occupation

\begin{tabular}{|c|c|c|c|c|c|c|c|c|c|c|c|c|c|c|c|c|}
\hline & \multicolumn{4}{|c|}{ All posts } & \multicolumn{4}{|c|}{ Professional and Technicians } & \multicolumn{4}{|c|}{ Merchants, Salesclerks \& Salespersons } & \multicolumn{4}{|c|}{ General Laborers } \\
\hline & Jan.-Feb. & April & May & June-Sept. & Jan.-Feb. & April & May & June- Sept. & Jan.-Feb. & April & May & $\begin{array}{l}\text { June- } \\
\text { Sept. }\end{array}$ & $\begin{array}{l}\text { Jan.- } \\
\text { Feb. }\end{array}$ & April & May & $\begin{array}{l}\text { June- } \\
\text { Sept. }\end{array}$ \\
\hline Observations & 92,662 & 35,206 & 24,070 & 153,152 & 38,205 & 12,347 & 9,998 & 56,795 & 16,333 & 7,834 & 5,283 & 33,384 & 9,093 & 5,640 & 2,384 & 19,499 \\
\hline Availability & 3 & 2 & 3 & 3 & 3 & 2 & 3 & 2 & 4 & 2 & 3 & 3 & 2 & 2 & 3 & 2 \\
\hline Travel & 6 & 7 & 7 & 7 & 6 & 7 & 6 & 7 & 8 & 7 & 7 & 9 & 5 & 7 & 8 & 8 \\
\hline Growth & 19 & 12 & 18 & 15 & 19 & 13 & 15 & 14 & 27 & 16 & 26 & 23 & 20 & 8 & 16 & 11 \\
\hline Development & 3 & 3 & 4 & 3 & 4 & 3 & 4 & 3 & 4 & 4 & 6 & 4 & 3 & 2 & 3 & 2 \\
\hline Training & 19 & 14 & 21 & 17 & 18 & 15 & 17 & 15 & 31 & 20 & 35 & 29 & 21 & 10 & 19 & 13 \\
\hline Bonus & 18 & 20 & 20 & 18 & 16 & 17 & 14 & 13 & 31 & 29 & 37 & 31 & 23 & 23 & 25 & 21 \\
\hline Benefits & 56 & 73 & 62 & 67 & 57 & 67 & 58 & 62 & 60 & 75 & 66 & 71 & 54 & 84 & 69 & 78 \\
\hline Insurance & 5 & 4 & 5 & 4 & 5 & 4 & 5 & 4 & 8 & 4 & 6 & 5 & 4 & 2 & 4 & 3 \\
\hline Commissions & 15 & 10 & 15 & 13 & 6 & 4 & 4 & 4 & 46 & 25 & 44 & 37 & 27 & 12 & 21 & 17 \\
\hline Base Wage & 29 & 20 & 30 & 26 & 28 & 24 & 28 & 25 & 46 & 23 & 43 & 37 & 32 & 16 & 30 & 22 \\
\hline Work at home & 1 & 2 & 3 & 3 & 1 & 2 & 4 & 4 & 1 & 2 & 4 & 4 & 0 & 0 & 1 & 1 \\
\hline Work on site & 1 & 1 & 2 & 2 & 1 & 1 & 1 & 2 & 2 & 1 & 3 & 2 & 1 & 0 & 1 & 0 \\
\hline $\begin{array}{l}\text { Work on site (in job } \\
\text { title) }\end{array}$ & 1 & 1 & 2 & 2 & 1 & 1 & 1 & 2 & 2 & 1 & 3 & 2 & 1 & 0 & 1 & 0 \\
\hline Health & 3 & 4 & 5 & 4 & 4 & 6 & 8 & 7 & 4 & 2 & 3 & 3 & 2 & 2 & 3 & 2 \\
\hline Distance & 0 & 0 & 0 & 0 & 0 & 0 & 0 & 0 & 0 & 0 & 0 & 0 & 0 & 0 & 0 & 0 \\
\hline Digital & 3 & 3 & 5 & 4 & 4 & 4 & 6 & 5 & 3 & 2 & 5 & 4 & 1 & 0 & 1 & 1 \\
\hline COVID & 0 & 0 & 1 & 1 & 0 & 1 & 1 & 2 & 0 & 0 & 0 & 1 & 0 & 0 & 1 & 0 \\
\hline
\end{tabular}

Note: Authors' calculations. See Table S1 for words in Spanish. Each row indicates the percentage of ads that include the word in the first column at least once. 


\section{Telecommuting}

As noted, the COVID-19 crisis might change the nature of work by increasing the possibility of telecommuting. To account for this mechanism, we analyze the possibility for different occupations. Following Monroy-Gómez-Franco (2020), we match the SINCO 2011 classification to a pivotal classification (ISCO-08) and we then use the methodology of Dingel and Neiman (2020) to determine whether a particular job can be performed remotely. This methodology relies on the work context (such as email use and type of work) and the general activities involved in a job (such as physical activity, manipulation of objects, machines, or equipment, or personal contact with customers or the public). Like Monroy-Gómez-Franco (2020), we classify sales personnel in stores as not adaptable to telecommuting (ISCO-08=5521), because most Mexican stores do not have delivery services or computer systems. However, a disadvantage of this methodology is that the concept applies by its nature to occupations rather than individual jobs, and there may be heterogeneity within occupations in the demand for telecommuting.

Figure 5 shows the proportion of adaptability to telecommuting for different occupations. Anecdotal evidence indicates that there may be increased demand in adaptable occupations during the pandemic (Oppenheimer, 2020; Stahl, 2020). Baldwin (2020) goes even further by suggesting that the pandemic will increase demand for telemigrants, that is, workers working from abroad in countries with lower wages. However, compared to the first two months of 2020, the demand for such jobs in Mexico decreased by 11 percentage points in April and by 6 percentage points in May. This decrease is related to the increase in demand in April for workers in support activities, such as cashiers and drivers, and the decrease in professional activities adaptable to telecommuting. June and July show a similar proportion of telecommuting as in May. Adaptability to telecommuting fell again in August-September, and the average for these jobs in the third quarter of 2020 was only 43 percent, which is 8 percentage points below pre-pandemic levels. In sum, there is thus far no empirical evidence that the nature of work is changing through an increase in demand for telecommuting.

Figure 5. Adaptability to telecommuting

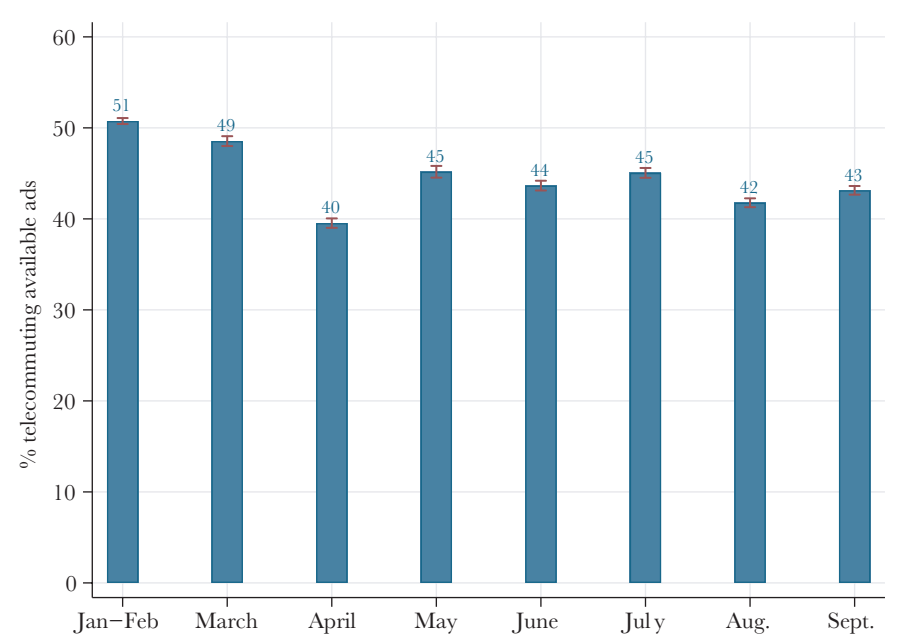

Notes: Authors' calculations. Adaptability to telecommuting was calculated using the methodology of MonroyGómez-Franco (2020), including translation of the SINCO 2011 classification to O*NET to classify occupations, as in Dingel and Neiman (2020).

\section{Change in Wages During the Pandemic}

Table 2 presents the distribution of average monthly wages offered in job ads by month. The average monthly wage fell in April but increased in May. In April there was not only a drop in average wage, but also a shift in the overall distribution, as seen in the wages across different percentiles. This drop in wages is related to the type of jobs in demand. April saw a decrease 
in demand in the best-paid occupations, such as professionals and technicians, and an increase in demand for low-paid workers in support positions. The increase in wages observed in May is related to the increase in demand in higher-paid occupations. In June and July, the distribution of wages returned to the January-February level, whereas in August and September the mean, median, and 90th percentile wages declined again.

Table 2. Distribution of Average Monthly Wages, by Month

\begin{tabular}{|c|c|c|c|c|c|}
\hline Period & Mean Wage (MXN) & 10th Percentile & 50th Percentile & 90th Percentile & No. of Obs. \\
\hline \multirow[t]{2}{*}{ January } & $\$ 13,172$ & $\$ 4,697$ & $\$ 9,394$ & $\$ 26,304$ & 53,500 \\
\hline & $(13,070-13,274)$ & $(4,697-4,697)$ & $(9,085-9,394)$ & $(25,834-26,774)$ & \\
\hline \multirow[t]{2}{*}{ February } & $\$ 13,830$ & $\$ 4,912$ & $\$ 9,823$ & $\$ 28,066$ & 38,508 \\
\hline & $(13,706-13,954)$ & $(4,732-5,146)$ & $(9,823,10,156)$ & $(27,599-28,066)$ & \\
\hline \multirow[t]{2}{*}{ March } & $\$ 14,185$ & $\$ 4,680$ & $\$ 10,296$ & $\$ 28,080$ & 33,910 \\
\hline & $(14,050-14,320)$ & $(4,586-4,680)$ & $(10,296-10,296)$ & $(28,080-28,548)$ & \\
\hline \multirow[t]{2}{*}{ April } & $\$ 12,335$ & $\$ 3,971$ & $\$ 7,649$ & $\$ 26,003$ & 35,020 \\
\hline & $(12,207-12,464)$ & $(3,971-4081)$ & $(7,565-7,943)$ & $(26,003-26,476)$ & \\
\hline \multirow[t]{2}{*}{ May } & $\$ 15,347$ & $\$ 4,710$ & $\$ 11,303$ & $\$ 30,614$ & 23,958 \\
\hline & $(15,177-15,516)$ & $(4,710-4,710)$ & $(11,303-11,303)$ & $(30,614-32,027)$ & \\
\hline \multirow[t]{2}{*}{ June } & $\$ 13,973$ & $\$ 4,684$ & $\$ 9,603$ & $\$ 28,105$ & 34,273 \\
\hline & $(13,837-14,110)$ & $(4,684-4,684)$ & $(9,368-9,837)$ & $(28,105-28,262)$ & \\
\hline \multirow[t]{2}{*}{ July } & $\$ 14,337$ & $\$ 4,654$ & $\$ 10,238$ & $\$ 28,387$ & 34,088 \\
\hline & $(14,194-14,479)$ & $(4,654-4,654)$ & $(10,238-10,238)$ & $(27,922-29,318)$ & \\
\hline \multirow[t]{3}{*}{ August } & $\$ 13,011$ & $\$ 4,635$ & $\$ 9,271$ & $\$ 26,421$ & 41,229 \\
\hline & $(12,898-13,123)$ & $(4,635-4,635)$ & $(9,271-9,271)$ & $(25,494-27,348)$ & \\
\hline & $\$ 13,294$ & $\$ 4,625$ & $\$ 9,249$ & $\$ 27,286$ & 41,683 \\
\hline September & $(13,175-13,412)$ & $(4,625-4,625)$ & $(9,249-9,249)$ & $(26,361-27,748)$ & \\
\hline
\end{tabular}

Note: Authors' calculations. Wages in pesos (MXN) of 2018m7. 95\% CI in parentheses, calculated using the binomial method.

To analyze the change across the full distribution we plot wage growth with respect to January-February by decile and month for the period April-September. Figure 6 shows the deciles for each month and the difference in average wage by decile. As seen in Table 2, the wage patterns are very different during April and May. In April, there is a decline in the average wage for each decile with respect to January-February: the wage distribution shifted to the left. By May, however, the pattern is reversed: there is wage growth in all deciles except the second one. The numbers for June and July reveal moderate increases in advertised wages across most of the distribution. However, in August and September there was a drop in the mean wage again in almost all the deciles. This drop was smaller than the drop during April. This figure is consistent with a temporary and significant change in labor demand during April that was quickly reversed in subsequent months. The observed wages in recent months are compatible with a significant slack in both economic activity and the labor market. 
Figure 6. Change in wages by decile with respect to January-February

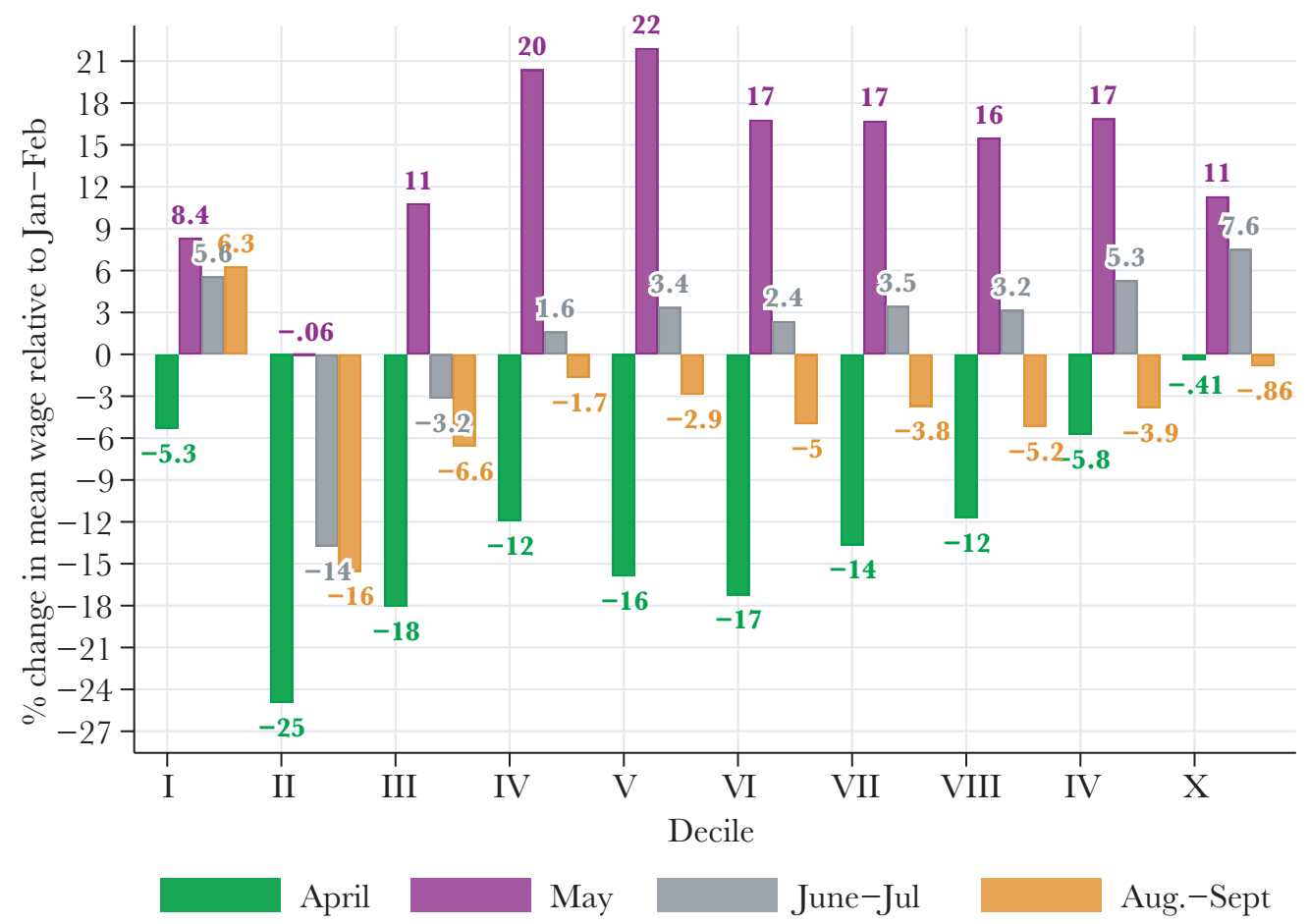

Notes: Authors' calculations. Deciles are calculated for each month and then the average monthly wage is calculated within each decile.

Finally, we implement a simple Oaxaca-Blinder decomposition to investigate what is behind the abrupt change in wages during April and May. The Oaxaca-Blinder decomposition helps to understand whether the change in average wage is due to a shift in the proportion of occupations in demand or to a change in wages within occupations. This decomposition consists in estimating two OLS regressions, one for the period January-February and the other for each month. The independent variables are occupation dummies at four digits. If coefficients are stable across months, the Explained component should not change that much. On the other hand, if the Unexplained component grows, it means the premium for each occupation is gaining in relevance.

Table 3 presents the results for the Oaxaca-Blinder decomposition with respect to January and February. ${ }^{4}$ The first rows indicate the average $(\log )$ wage of each month. April was the month most affected. The gap was 0.04 in March, but by April it decreased to -0.13 (log points). However, by June and July it had largely recovered, with a small decrease during August and September. The Explained component row indicates the share of the total differential explained by the characteristics. This explained component proportion is very stable with the exception only of July, when it grows. This implies that the variation in wages observed throughout the period is mainly due to a change in demand for occupations and not a change in wages within occupations. For the specific case of the significant reduction in the average advertised wage in April, this result implies that it is due to a higher proportion of job ads for low-wage occupations than by a reduction in the wages paid for given occupations. 
Table 3. Oaxaca-Blinder Decomposition

\begin{tabular}{|c|c|c|c|c|c|c|c|}
\hline & March & April & May & June & July & August & September \\
\hline \multicolumn{8}{|c|}{ Differential } \\
\hline \multirow[t]{2}{*}{ Current month } & 9.29 & 9.11 & 9.36 & 9.26 & 9.29 & 9.20 & 9.21 \\
\hline & {$[.002]$} & {$[.0022]$} & {$[.0023]$} & {$[.002]$} & {$[.0019]$} & {$[.0017]$} & {$[.0018]$} \\
\hline \multirow[t]{2}{*}{ January-February } & 9.24 & 9.24 & 9.24 & 9.24 & 9.24 & 9.24 & 9.24 \\
\hline & {$[.0011]$} & {$[.0011]$} & {$[.0011]$} & {$[.0011]$} & {$[.0011]$} & {$[.0011]$} & {$[.0011]$} \\
\hline \multirow[t]{2}{*}{$\begin{array}{l}\text { Difference current month vs. } \\
\text { Jan.-Feb. }\end{array}$} & 0.04 & -0.13 & 0.12 & 0.02 & 0.05 & -0.04 & -0.03 \\
\hline & {$[.0022]$} & {$[.0024]$} & {$[.0026]$} & {$[.0023]$} & {$[.0022]$} & {$[.002]$} & {$[.002]$} \\
\hline \multicolumn{8}{|c|}{ Decomposition } \\
\hline$\%$ Explained & 0.32 & 0.29 & 0.32 & 0.30 & 0.49 & 0.30 & 0.36 \\
\hline$\%$ Unexplained & 0.68 & 0.71 & 0.68 & 0.70 & 0.51 & 0.70 & 0.64 \\
\hline Observations in current month & 32,568 & 34,081 & 22,813 & 32,813 & 32,562 & 39,755 & 40,044 \\
\hline Observations in Jan.-Feb. & 88,279 & 88,279 & 88,279 & 88,279 & 88,279 & 88,279 & 88,279 \\
\hline Total number of observations & 120,847 & 122,360 & 111,092 & 121,092 & 120,841 & 128,034 & 128,323 \\
\hline
\end{tabular}

Notes: Authors' calculations. Standard errors in brackets.

\section{Heterogenous Effects by Region and Gender}

In this section, we show the heterogeneity of the results by region and gender. We divide the country into four regions: center, north, south, and north-center. Figure 7 presents the disaggregation by region for the main occupations that changed during the pandemics. First, the percentage of professionals and technicians fell during the first months. This effect seems to be lasting in all the regions, except for the center, where there is a stable percentage of professionals after April. Second, administrative support staff increased slightly after the pandemic, especially in the south, where it increased constantly throughout the year. Third, in all regions the percentage of merchants, salesclerks, and salespersons increased after April, especially in the north and south. Finally, the percentage of general laborers surged in April, decreased in May, and increased slowly in all regions in subsequent months.

In sum, based on Figure 7, the recovery of high paid occupations (professionals and technicians) occurred especially in the center, which accounts for half of the total number of job ads. Meanwhile, the increase in low-paid occupations, such as general workers and merchants, occurred especially in the south, which contains 6 percent of the whole sample. 
Figure 7. Occupations by region as percentage of total job ads

A. Professionals and technicians

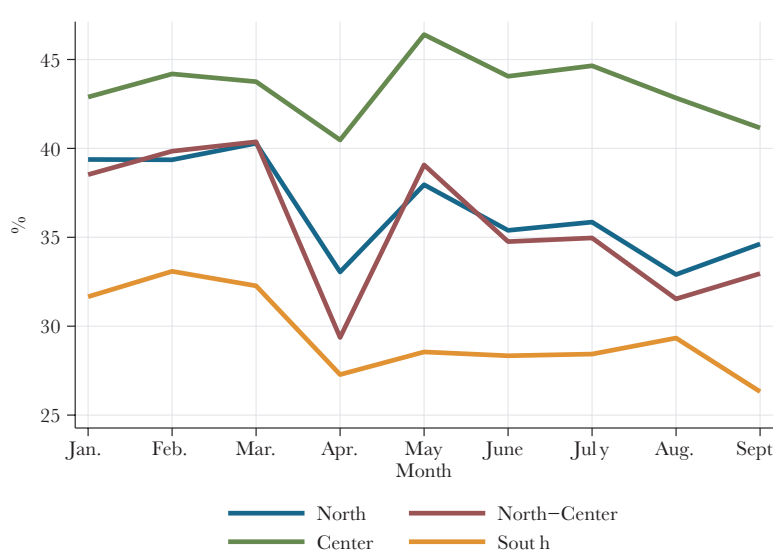

C. Merchants, salesclerks, and salespersons

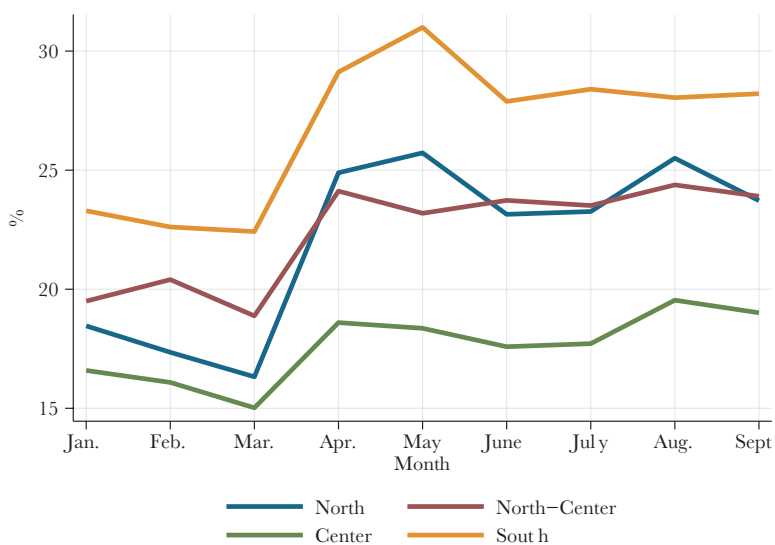

B. Administrative support staff

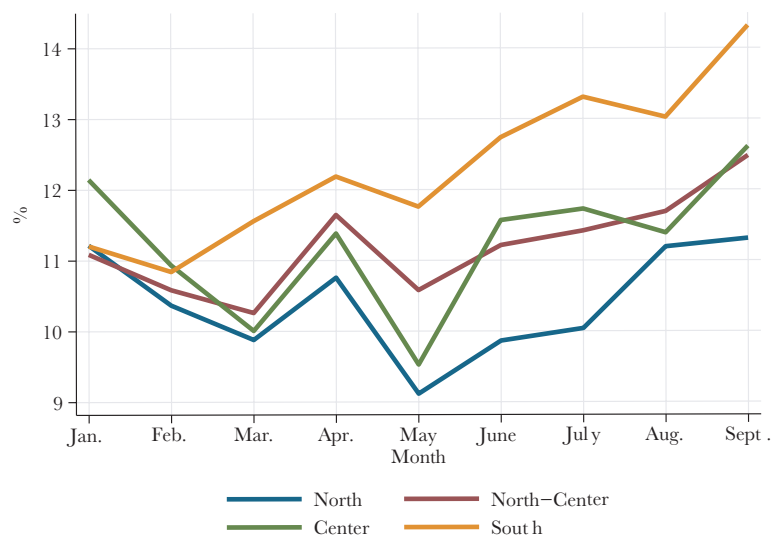

D. General laborers

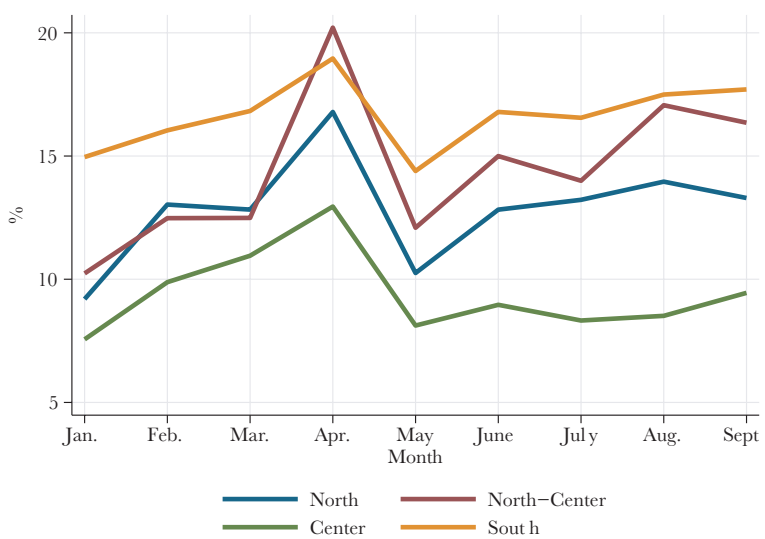

Note: Authors' calculations. Center includes Mexico City, Guanajuato, Hidalgo, Estado de México, Morelos, Puebla, Querétaro and Tlaxcala; North-Center includes Aguascalientes, Baja California Sur, Colima, Durango, Jalisco, Michoacán, Nayarit, San Luis Potosí, Sinaloa, and Zacatecas; North includes Baja California, Coahuila, Chihuahua, Nuevo León, Sonora, and Tamaulipas; and South includes Campeche, Chiapas, Guerrero, Oaxaca, Quintana Roo, Tabasco, Veracruz, and Yucatán.

Figure 8 shows the adaptability to telecommuting by region. Adaptability to telecommuting is higher in the center and north than in the rest of the country, which is consistent with results of Monroy-Gómez-Franco (2020). In April, the proportion of telecommuting jobs decreased, followed by a recovery in May. However, there is a persistent decrease in the south in adaptability to telecommuting. This decrease is related to the structure of demand in that region, where demand for merchants, general laborers, and support staff increased, as shown in Figure 7.

Finally, in Figure 9 we show the mean monthly wage by region. The highest wages offered are, as expected, in the center and north. All regions except the center showed a decline in the average advertised wage during April. In that month, the greatest effect on wages was in the north-center, which recovered in May, but then declined from June to September, similar to what occurred in the south. 
Figure 8. Adaptability to telecommuting by region

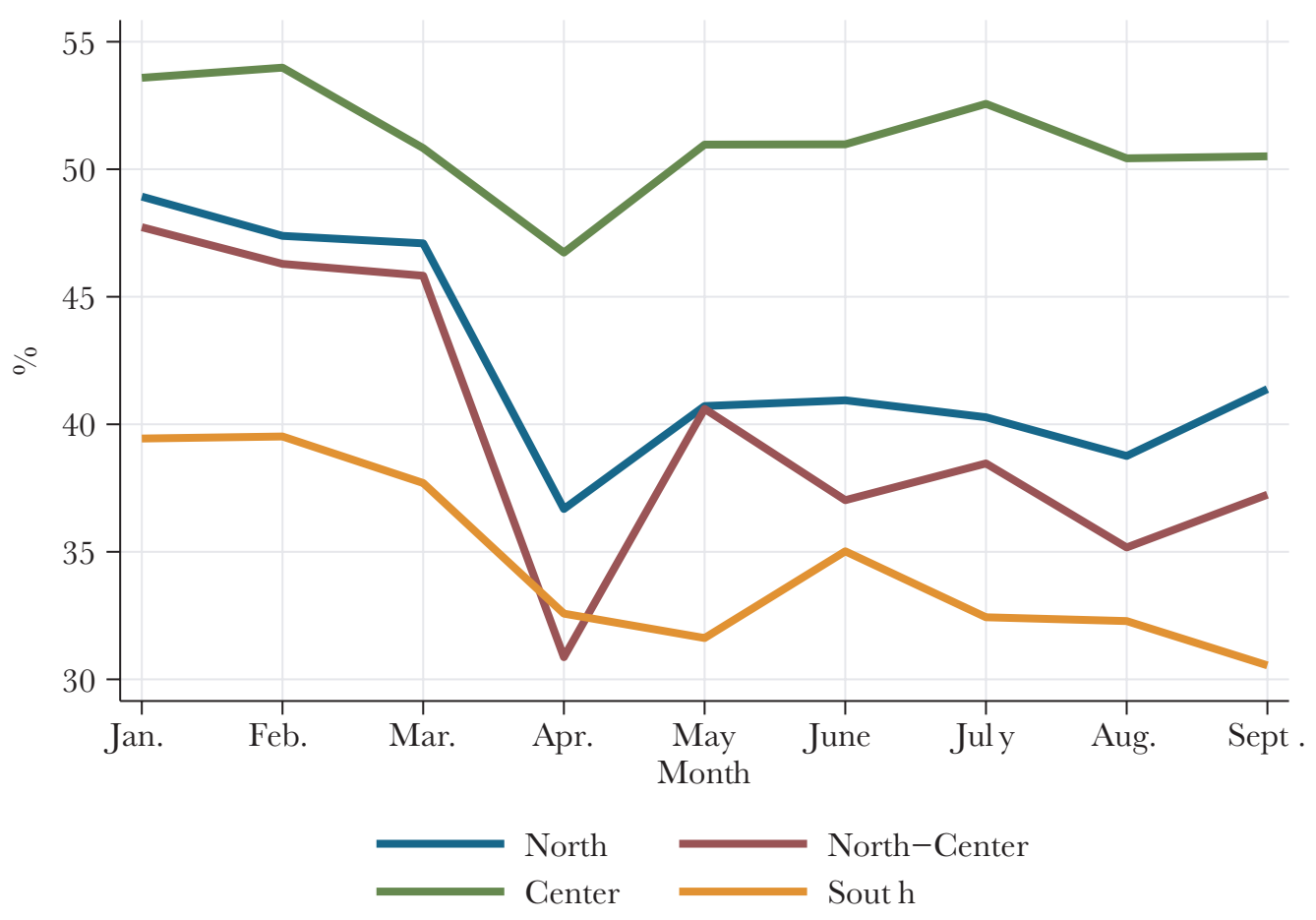

Note: Authors' calculations. See notes to Figure 7 for definitions of regions.

Figure 9. Mean wage by region

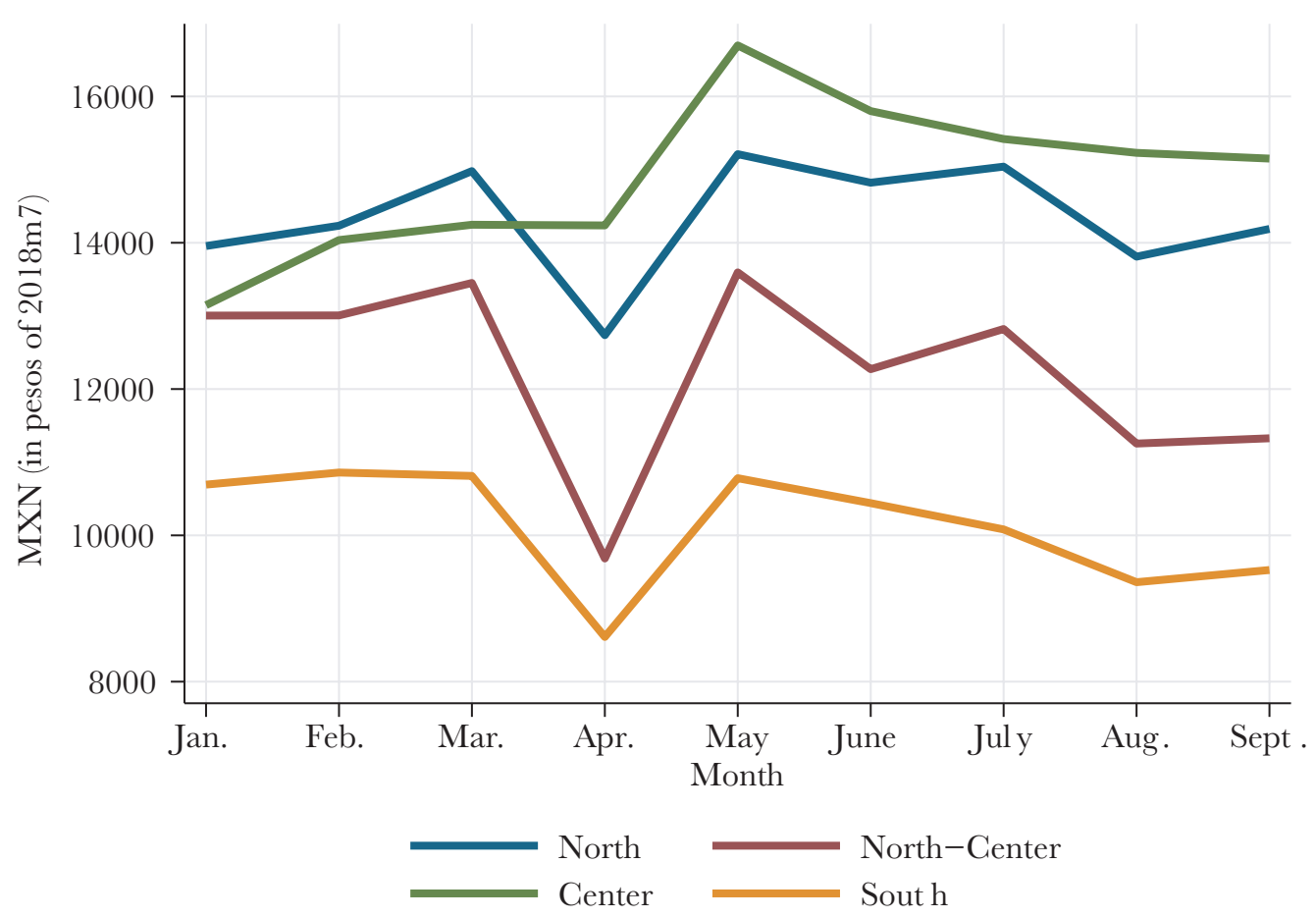

Note: Authors' calculations. See notes of Figure 7 for definitions of regions.

To observe the heterogeneity in job ads by gender, we classified the ads into three categories: specifies men (2.2 percent of the sample in January), specifies women (2.3 percent), and gender-neutral (95.5 percent). Figures 10-12 show the results of this analysis. Figure 10 shows the gender distribution by occupation as a percentage of the total number of job ads. The distribution for women is similar to that for gender-neutral ads, except for administrative support staff. 
Ads targeting men are more common for general laborers. In April, the percentage of ads for general laborers that explicitly specified men increased to 30 percent and remained thereafter at a higher level than in January-February.

Figure 10. Gender distribution by occupation as percentage of total number of job ads

A. Professionals and technicians

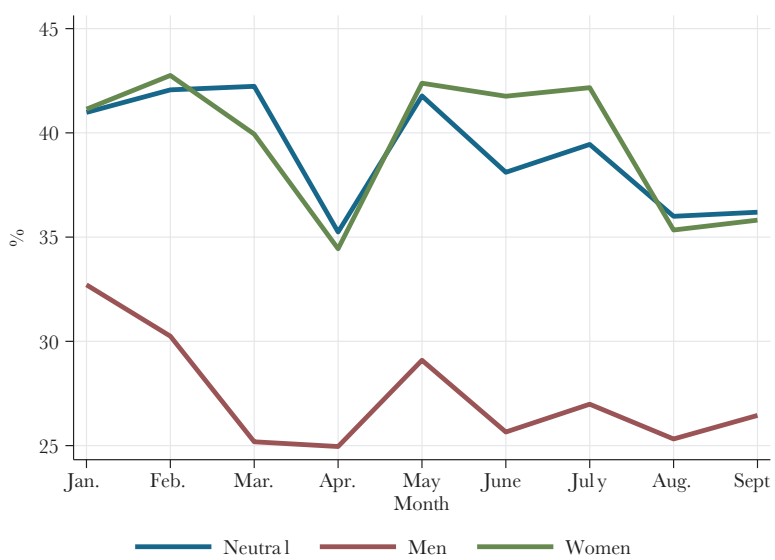

C. Merchants, salesclerks, and salespersons

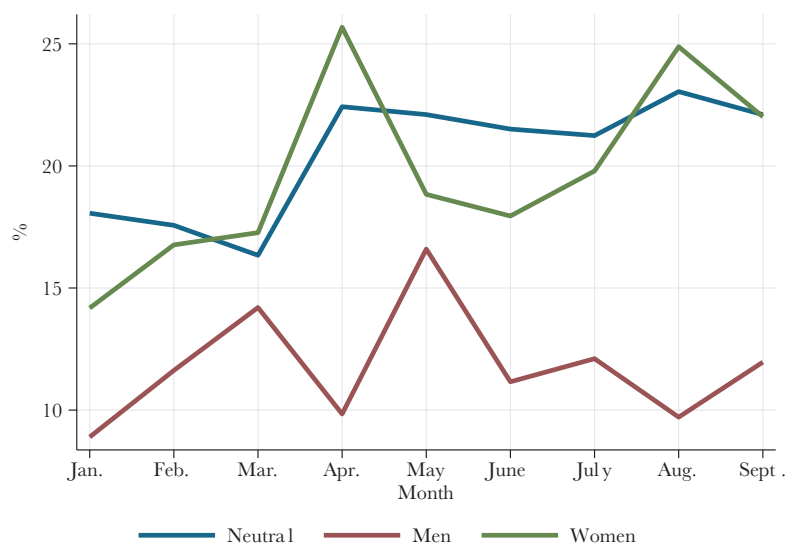

B. Administrative support staff

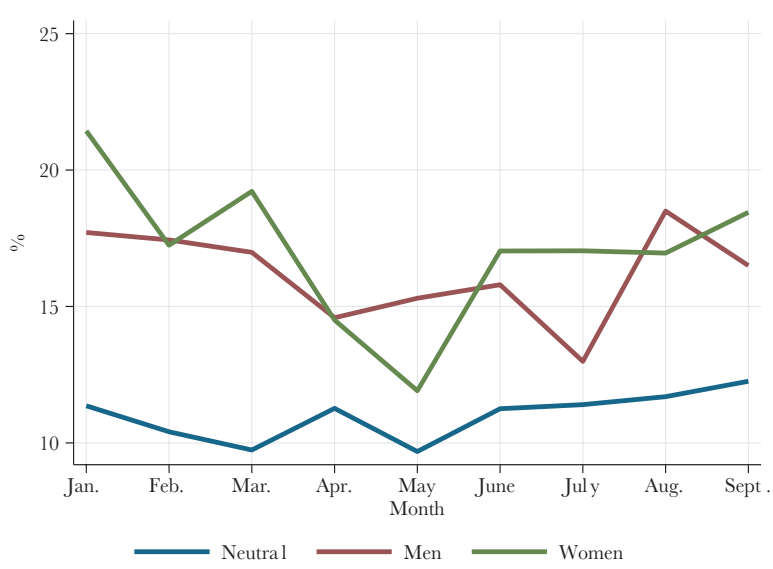

D. General laborers

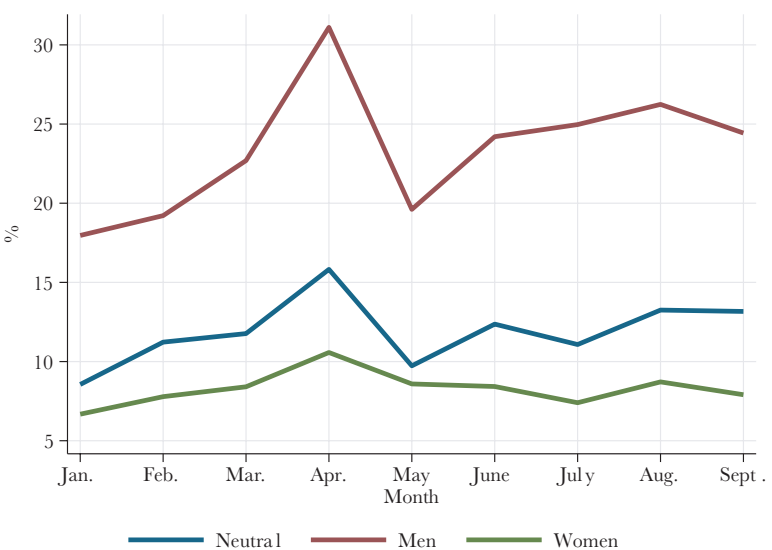

Note: Authors' calculations.

Figure 11 shows the adaptability to telecommuting by gender. Ads that explicitly specify women are in general more adaptable to telecommuting than neutral ads and those targeted to men. The proportion of jobs available for telecommuting decreased more for those targeted to men. This decrease could be related to the increase in the number of ads for general laborers. Finally, Figure 12 shows that ads targeted specifically to men or women usually offer lower wages than neutral ads, but show the same trends as neutral ads.

In sum, there is heterogeneity of results by region and gender. Ads for low-wage occupations seem to be persistent and increasing in the south, which the recovery for higher-paid occupations occurred mainly in the center. Adaptability to telecommuting was negatively affected in the south, while it remained almost the same in the center. While in general ads targeted at women follow the trends of neutral ads, those targeted at men occur are particularly prevalent for general laborers. The demand for male general laborers increased in April and remained high until September. This increase is related to the marked decrease in the availability of telecommuting ads targeted at men. 
Figure 11. Adaptability to telecommuting by gender

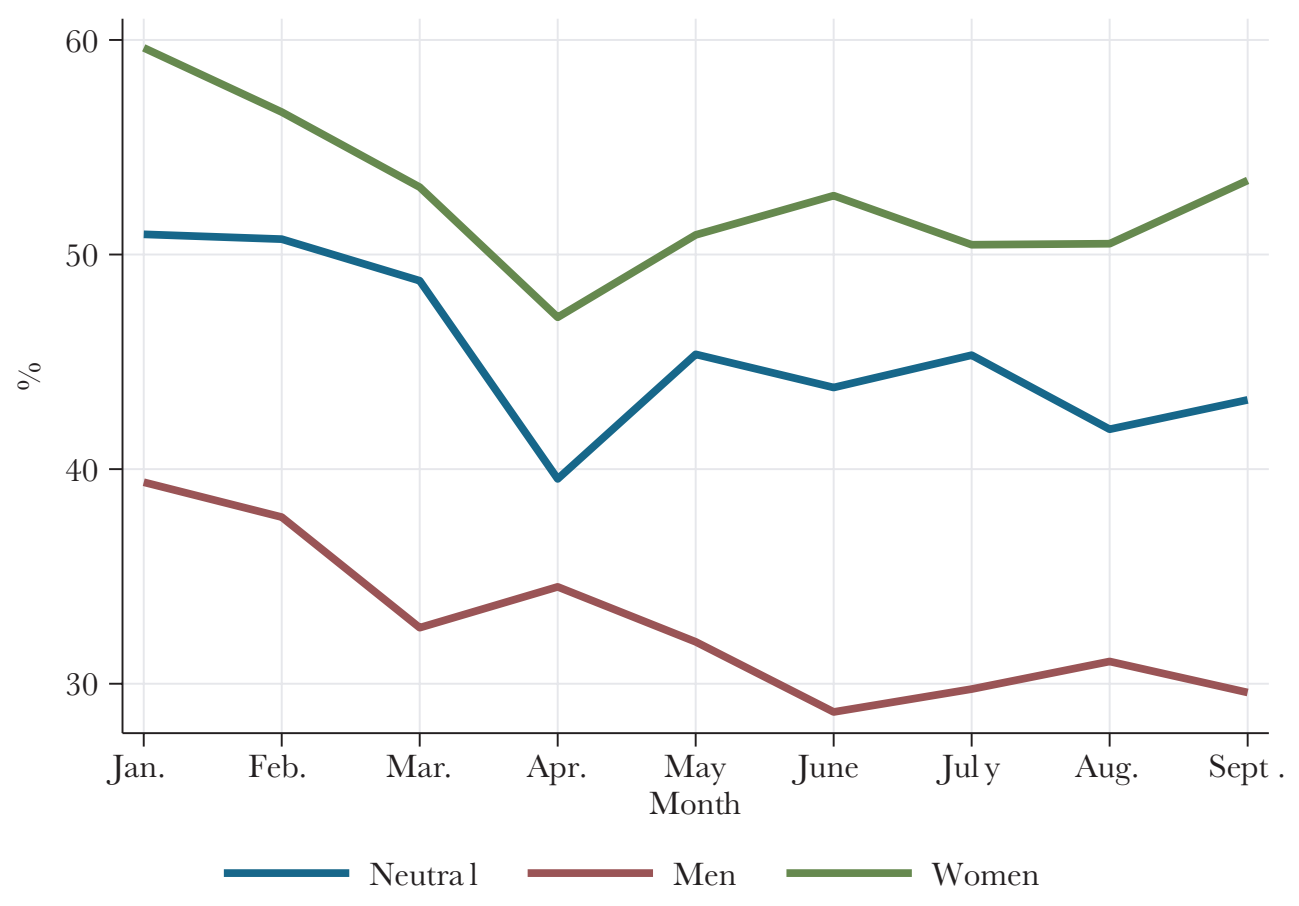

Note: Authors' calculations.

Figure 12. Mean wage by region

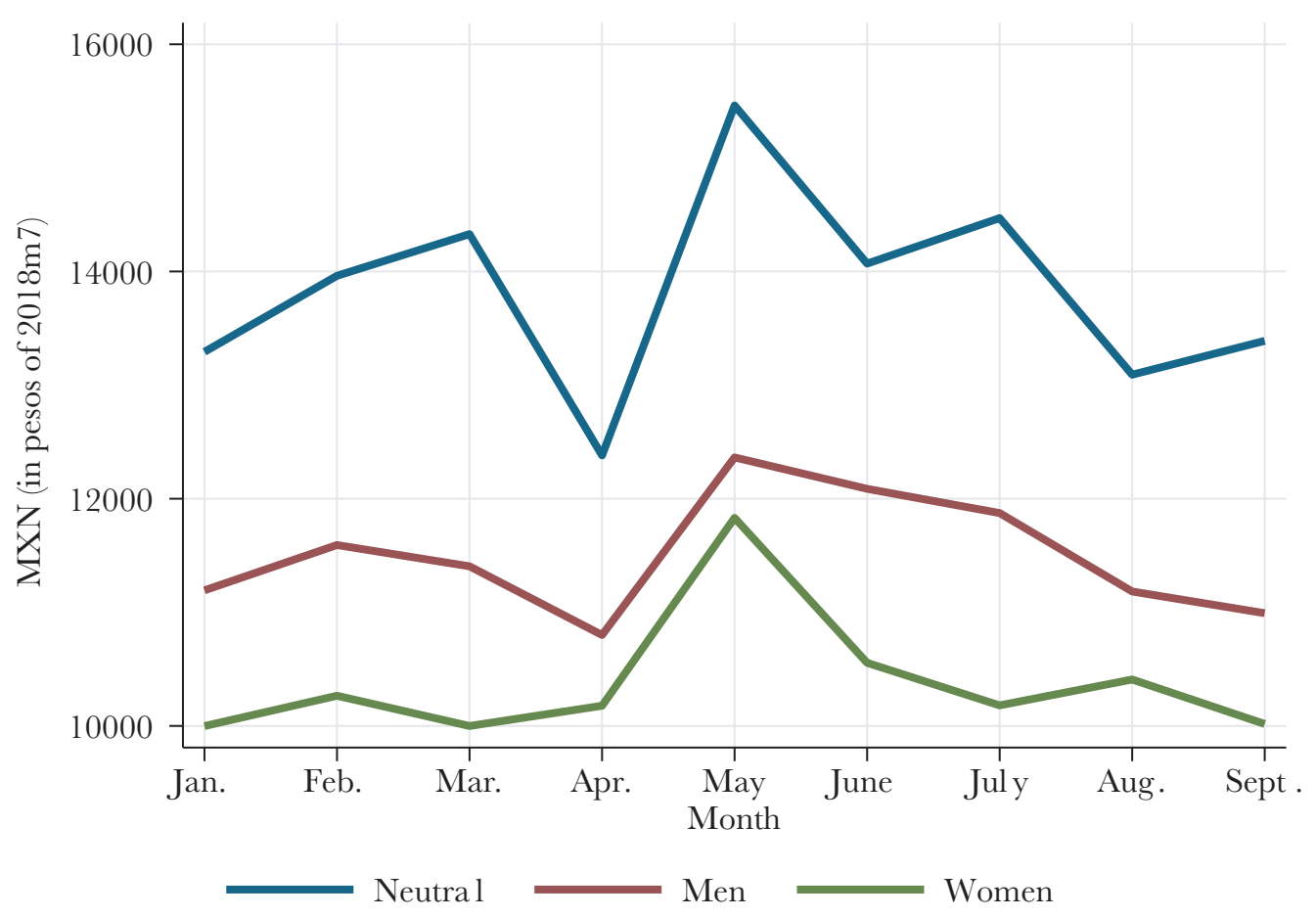

Note: Authors' calculations.

\section{Conclusions and discussion}

The COVID-19 crisis has had a major impact on the economy and the labor market. As a result, there are valid concerns that this crisis might permanently change the nature of work. Using job ads from a leading job search website in Mexico, we show that there is no evidence thus 
far to support this concern. We download 339,224 ads from January to September 2020 and analyze the jobs advertised and the posted wages, and we use text analysis to analyze the skills and personal characteristics sought. We find that there is a decline in the number of job advertisements, but that there is no structural change in labor demand. As in the U.S. (Chetty et al. 2020; Forsythe, Kahn, Lange, \& Wiczer 2020), the number of vacancies declined sharply in the early stages of the pandemic (around 38 percent) due to the implementation of mobility restrictions. By September, the number of vacancies had recovered. Most importantly, however, the structure of labor demand changed only temporarily: there was greater demand for low-wage occupations and workers with low educational levels in April, but from May to July demand was back to pre-pandemic levels. The possibilities offered for telecommuting did not increase in this period, and there was no fundamental change in the skills and personal characteristics sought.

Why did Mexican labor demand not adjust to other working options? Like most of the countries in Latin America, Mexico has a low availability of work from home (Cardenas and Montana, 2020). ${ }^{5}$ The lack of flexibility in labor demand could be caused by the sorting in skills required for telecommuting. The more telecommuting is available, the more skills are required (Malkov, 2020; Cardenas and Montana, 2020). In the short run, then, Mexican labor markets may have had barriers to adapting their labor demand to more flexible jobs, likely because of the set of skills and types of jobs that telecommuting requires. This pattern could also be aggravated by lax enforcement of social distancing measures.

Future research should continue to monitor the behavior of labor demand. Qualitative and case studies are also necessary to investigate changes in the nature of work within occupations and within firms. It is plausible that job ads and aggregate data on employment do not account for small changes in the employer-employee relationship. These small changes might be the causal mechanism that explains future structural changes in the nature of work.

\section{References}

Al Masri, A., Flamini, V., \& Toscani, F. (2021). The Short-Term Impact of COVID-19 on Labor Markets, Poverty and Inequality in Brazil International Monetary Fund (IMF) Working paper (2021/066). Retrieved from https://www.imf.org/en/Publications/WP/ Issues/2021/03/05/The-Short-Term-Impact-of-COVID-19-on-Labor-Markets-Povertyand-Inequality-in-Brazil-50124

Arceo-Gómez, E. O., Campos-Vázquez, R. M., Badillo-Salas, R. Y., \& López-Araiza, S. (2020). Gender Stereotypes in Fob Advertisements: What Do they Imply for the Gender Salary Gap? Mexico. Retrieved from http://conference.iza.org/conference files/DATA_2020/campos\%20 vazquez_r4830.pdf

Baldwin, R. E. (2020). Covid, hysteresis, and the future of work. https://voxeu.org/article/ covid-hysteresis-and-future-work

Barrero, J. M., Bloom, N., \& Davis, S. (2020). COVID-19 Is Also a Reallocation Shock. National Bureau of Economic Research (NBER) Working Papers (No. 27137). https://doi. org/10.3386/w27137

Brenčič, V. (2012). Wage posting: evidence from job ads. Canadian fournal of Economics/Revue Canadienne d'économique, 45(4), 1529-1559. https://doi.org/10.1111/j.1540-5982.2012.01738.x

Brown, J., \& Matsa, D. A. (2016). Boarding a Sinking Ship? An Investigation of Job Applications to Distressed Firms. The Journal of Finance, 71(2), 507-550. https://doi.org/10.1111/ jofi. 12367

5 Cardenas and Montana (2020) found that the share of workers who can work from home is 22 percent in Mexico, 31 percent in Argentina, 27 percent in Chile, 21 percent in Colombia, and 20 percent in Perú. 
Cardenas, J., \& Montana, J. (2020). The occupational structure of Latin American Countries and worker exposure to COVID. Colombia Científica. Documentos Alianza EFI (D2-2020-003). https:// doi.org/ 10.13140/RG.2.2.23761.35685

Chetty, R., Friedman,J. N., Hendren, N., Stepner, M., \& the Opportunity Insights Team. (2020). How Did COVID-19 and Stabilization Policies Affect Spending and Employment? A New Real-Time Economic Tracker Based on Private Sector Data. Retrieved from https://opportunityinsights.org/ wp-content/uploads/2020/05/tracker_paper.pdf

Choi, S., Banfi, S., \& Villena-Roldan, B. (2019). Sorting On-Line and On-Time. Social Sciencie Research Network (SSRN) Electronic Journal (No. 3323068). https://doi.org/10.2139/ ssrn.3323068

Chowdhury, A. R., Areias, A. C., Imaizumi, S., Nomura, S., \& Yamauchi, F. (2018). Reflections of Employers' Gender Preferences in Fob Ads in India: An Analysis of Online Job Portal Data. The World Bank. Policy Research Working Papers (No. 8379). https://doi.org/10.1596/1813-94508379

Dingel, J., and B. Neiman. (2020). How Many Jobs Can be Done at Home? National Bureau of Economic Research (NBER) Working Papers (No. 26948). https://doi.org/ 10.3386/w26948

Egaña del Sol, P., Cruz, G., \& Micco, A. (2021). COVID-19's Impact on the Labor Market Shaped by Automation: Evidence from Chile. Social Science Research Network (SSRN) Electronic Journal (No. 3761822). https://doi.org/10.2139/ssrn.3761822

Faberman, J. R., \& Kudlyak, M. (2016). What Does Online Job Search Tell Us about the Labor Market? Economic Perspectives, 40(1), 15. Retrieved from https://www.chicagofed.org/publications/economic-perspectives/2016/1-faberman-kudlyak

Forsythe, E., Kahn, L. B., Lange, F., \& Wiczer, D. G. (2020). Labor Demand in the Time of COVID-19: Evidence from Vacancy Postings and UI Claims. National Bureau of Economic Research (NBER) Working Papers (No. 27061). https://doi.org/10.1017/ CBO9781107415324.004

Hershbein, B., \& Kahn, L. B. (2018). Do Recessions Accelerate Routine-Biased Technological Change? Evidence from Vacancy Postings. American Economic Review, 108(7), 1737-1772. https://doi.org/10.1257/aer.20161570

Komatsuzaki, T., Pienknagura, S., Pizzinelli, C., Roldós, J., \& Toscani, F. (2020). Latin American Labor Markets during COVID-10. International Monetary Fund (IMF) (Issue October). Retrieved from https://www.imf.org/ /media/Files/Publications/REO/WHD/2020/ Oct/English/Labor.ashx?la=en

Kuhn, P., \& Shen, K. (2013a). Do Chinese Employers Avoid Hiring Overqualified Workers? Evidence from an Internet Job Board. Research in Labor Economics: Vol. 37. Labor Market Issues in China (pp. 1-30). https://doi.org/doi:10.1108/S0147-9121(2013)0000037005

Kuhn, P., \& Shen, K. (2013b). Gender Discrimination in Job Ads: Evidence from China. The Quarterly Fournal of Economics, 128(1), 287-336. https://doi.org/10.1093/qje/qjs046

Kuhn, P., \& Shen, K. (2015). Do employers prefer migrant workers? Evidence from a Chinese job board. IZA Fournal of Labor Economics, 4(1), 22. https://doi.org/10.1186/s40172-015-0038-0

Malkov, E. (2020). Nature of Work and Distribution of Risk: Evidence from Occupational Sorting, Skills, and Tasks. Social Science Research Network (SSRN) Electronic Journal, (No. 3643287), 1-21. https://doi.org/10.2139/ssrn.3643287

Marinescu, I., \& Rathelot, R. (2018). Mismatch Unemployment and the Geography of Job Search. American Economic Fournal: Macroeconomics, 10(3), 42-70. https://doi.org/10.1257/ mac.20160312 
Marinescu, I., \& Wolthoff, R. (2020). Opening the Black Box of the Matching Function: The Power of Words. Fournal of Labor Economics, 38(2), 535-568. https://doi.org/10.1086/705903

Modestino, A. S., Shoag, D., \& Ballance, J. (2019). Upskilling: Do Employers Demand Greater Skill When Workers are Plentiful? The Review of Economics and Statistics, 0, 1-46. https://doi. org/10.1162/rest_a_00835

Monroy-Gómez-Franco, Luis. (2020). ¿Quién Puede Trabajar Desde Casa ? Evidencia Desde México. Documento de trabajo Centro de Estudios Espinoza Yglesias (CEEY) (No. 06 / 2020). Retrieved from: https://ceey.org.mx/wp-content/uploads/2020/05/06-Monroy-Gómez-Franco-2020.pdf.

Oppenheimer, A. (2020). El trabajo, después del Covid-19. La Nación. Retrieved from https:// www.lanacion.com.ar/opinion/el-trabajo-despues-del-covid-19-nid2381283

Stahl, A. (2020). What Does Covid-19 Mean For the Future of Work. Forbes. Retrieved from https://www.forbes.com/sites/ashleystahl/2020/06/15/what-does-covid-19-mean-forthe-future-of-work/\#5c8a0efa446f

Von Gaudecker, H.-M., Holler, R., Janys, L., Siflinger, B., \& Zimpelmann, C. (2020). Labour supply in the early stages of the CoViD-19 Pandemic: Empirical Evidence on hours, home office, and expectations. IZA Institute of Labor Economics. Discussion Paper Series (No. 13158). Retrieved from http://ftp.iza.org/dp13158.pdf 


\section{Supplementary Material}

Table S1. Translation of Words in Table 2

\begin{tabular}{|c|c|c|}
\hline \multicolumn{3}{|c|}{ Words } \\
\hline & English & Spanish \\
\hline \multirow{31}{*}{ 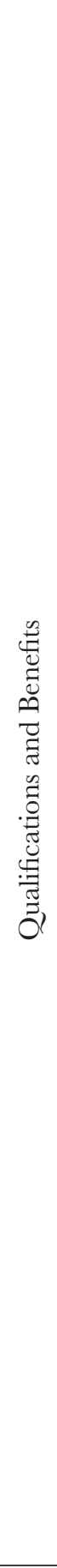 } & Commitment & Compromiso \\
\hline & Punctual & Puntual \\
\hline & Honest & Honesto \\
\hline & Attentive & Atento \\
\hline & Teamwork & Trabajo en Equipo \\
\hline & Helpful & Servicial \\
\hline & Courteous & Amable \\
\hline & Control & Control \\
\hline & Initiative & Iniciativa \\
\hline & Pressure & Presión \\
\hline & Proactive & Proactivo \\
\hline & Responsible & Responsable \\
\hline & Motivated & Motivado \\
\hline & Leadership & Liderazgo \\
\hline & Requests photograph & Foto \\
\hline & Specifies good appearance & Presentación \\
\hline & English & Inglés \\
\hline & Common computer software & Software \\
\hline & Sales & Ventas \\
\hline & Customer & Cliente \\
\hline & Follow-up & Seguimiento \\
\hline & Availability & Disponibilidad de tiempo \\
\hline & Travel & Viajar \\
\hline & Growth & Crecimiento \\
\hline & Development & Desarrollo \\
\hline & Training & Capacitación \\
\hline & Bonus & Bono \\
\hline & Benefits & Prestaciones \\
\hline & Insurance & Seguro \\
\hline & Commissions & Comisiones \\
\hline & Base wage & Salario Base \\
\hline \multirow{7}{*}{ 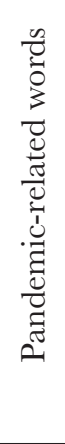 } & Work at home & Trabajo en Casa \\
\hline & Work on site & Trabajo Presencial \\
\hline & Work on site (in job title) & $\begin{array}{l}\text { Trabajo Presencial (en el título } \\
\text { del empleo) }\end{array}$ \\
\hline & Health & Salud \\
\hline & Distance & Distancia \\
\hline & Digital & Digital \\
\hline & COVID & Covid \\
\hline
\end{tabular}


Table S2. Translation of Occupations in Figure 4

English

Officers, directors, and managers

Professionals and technicians

Administrative support staff

Merchants, salesclerks, and salespersons

Workers in personal services and security

Workers in agriculture, livestock, forestry, hunting, and fishing

Handicraft workers

Industrial machine operators, assemblers, and drivers

General laborers
Spanish

Funcionarios, directores y jefes

Profesionistas y técnicos

Trabajadores auxiliares en actividades administrativas

Comerciantes, empleados en ventas y agentes de ventas

Trabajadores en servicios personales y vigilancia

Trabajadores en actividades agrícolas, ganaderas, forestales, caza y pesca

Trabajadores artesanales

Operadores de maquinaria industrial, ensambladores, choferes y conductores de transporte

Trabajadores en actividades elementales y de apoyo

Table S3. Most Frequent Words in Figure 5

\begin{tabular}{ccccc} 
English & Spanish & English & Spanish \\
\cline { 1 - 2 } Engineer & Ingeniero & Supervisor & Supervisor \\
Commercial & Comercial & Cashier & Gajero \\
Supervisor & Jefe & Helper & Ayudante \\
Gredit & Crédito & Technician & Técnico \\
Administrative & Administrativo & Analyst & Analista \\
Developer & Desarrollador & General & General \\
Operator & Operador & Manager & Gerente \\
Promoter & Promotor & Salesperson & Vendedor \\
Physician & Médico & Consultant & Asesor \\
Collection & Cobranza & Account Exec- & Ejecutivo \\
Security & Seguridad & Support & Auxiliar \\
Coordinator & Coordinador & Sales & Ventas \\
Driver & Chofer & Production & Producción \\
& & & &
\end{tabular}


Table S4. Descriptive Statistics for Relevant Variables

\begin{tabular}{|c|c|c|c|c|c|c|c|c|c|c|}
\hline & Variables & Jan. & Feb. & March & April & May & June & July & Aug. & Sept. \\
\hline & $\begin{array}{l}\text { Number of ob- } \\
\text { servations }\end{array}$ & 53,828 & 38,834 & 34,134 & 35,206 & 24,070 & 34,375 & 34,158 & 41,284 & 43,335 \\
\hline \multirow{19}{*}{ 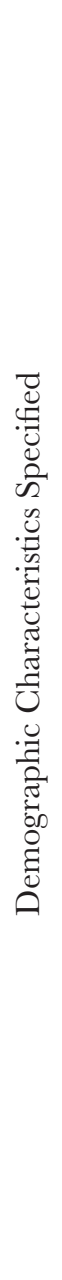 } & Specifies women & 2.25 & 2.15 & 1.95 & 0.94 & 1.50 & 1.59 & 1.70 & 1.53 & 1.49 \\
\hline & Specifies men & 2.19 & 2.17 & 2.00 & 1.62 & 1.93 & 2.01 & 2.32 & 2.10 & 1.83 \\
\hline & Specifies location & 99.05 & 99.33 & 99.40 & 99.01 & 98.59 & 92.38 & 98.12 & 90.56 & 92.45 \\
\hline & Includes wage & 99.39 & 99.16 & 99.34 & 99.47 & 99.53 & 99.70 & 99.80 & 99.87 & 96.19 \\
\hline & $\begin{array}{l}\text { Mean real Wage } \\
\text { (MXN/mo.) }\end{array}$ & $\$ 13,172$ & $\$ 13,830$ & $\$ 14,185$ & $\$ 12,335$ & $\$ 15,347$ & $\$ 13,973$ & $\$ 14,337$ & $\$ 13,011$ & $\$ 13,294$ \\
\hline & $\begin{array}{l}\text { Specifies mini- } \\
\text { mum age }\end{array}$ & 15.72 & 15.63 & 13.82 & 7.68 & 12.77 & 11.65 & 12.32 & 10.28 & 10.57 \\
\hline & $\begin{array}{l}\text { Specifies maxi- } \\
\text { mum age }\end{array}$ & 12.66 & 12.46 & 11.00 & 6.22 & 10.18 & 9.19 & 9.56 & 8.10 & 8.37 \\
\hline & $\begin{array}{l}\text { Mean minimum } \\
\text { age }\end{array}$ & 24.88 & 25.12 & 25.21 & 25.31 & 25.56 & 25.47 & 25.30 & 25.53 & 25.21 \\
\hline & $\begin{array}{l}\text { Mean maximum } \\
\text { age }\end{array}$ & 39.64 & 39.68 & 40.05 & 41.46 & 41.55 & 40.40 & 40.17 & 40.26 & 40.41 \\
\hline & $\begin{array}{l}\text { Specifies experi- } \\
\text { ence }\end{array}$ & 70.70 & 71.67 & 79.83 & 79.43 & 80.44 & 80.33 & 79.78 & 80.16 & 81.49 \\
\hline & Specifies married & 0.29 & 0.26 & 0.25 & 0.14 & 0.32 & 0.32 & 0.40 & 0.28 & 0.24 \\
\hline & Specifies single & 0.12 & 0.12 & 0.08 & 0.06 & 0.10 & 0.11 & 0.06 & 0.08 & 0.13 \\
\hline & Specifies student & 3.12 & 2.95 & 2.96 & 1.66 & 1.95 & 1.79 & 1.94 & 1.68 & 2.04 \\
\hline & $\begin{array}{l}\text { Jr. high school } \\
\text { diploma }\end{array}$ & 4.00 & 3.45 & 7.78 & 16.64 & 6.94 & 10.43 & 8.25 & 11.60 & 11.27 \\
\hline & High school & 9.98 & 9.37 & 10.00 & 15.58 & 10.62 & 12.03 & 10.50 & 12.78 & 12.53 \\
\hline & Some school & 7.52 & 7.66 & 7.58 & 5.74 & 6.60 & 6.55 & 7.37 & 6.86 & 6.84 \\
\hline & Tech. cert. & 1.95 & 2.02 & 2.25 & 1.37 & 2.20 & 1.97 & 2.12 & 1.79 & 1.84 \\
\hline & Bachelor's degree & 38.86 & 39.89 & 38.99 & 30.97 & 38.66 & 35.50 & 36.18 & 34.21 & 33.96 \\
\hline & Engineer's degree & 19.04 & 20.65 & 21.10 & 14.45 & 20.62 & 18.16 & 19.69 & 16.46 & 17.91 \\
\hline \multirow{5}{*}{ 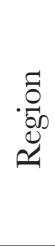 } & Center & 57.52 & 56.03 & 56.27 & 44.75 & 49.06 & 43.78 & 46.98 & 39.37 & 42.11 \\
\hline & North-center & 13.74 & 14.13 & 13.93 & 23.18 & 18.42 & 18.52 & 19.87 & 20.56 & 19.95 \\
\hline & North & 21.05 & 22.23 & 22.86 & 20.44 & 22.29 & 21.03 & 22.25 & 21.43 & 21.61 \\
\hline & South & 6.73 & 6.93 & 6.34 & 10.65 & 8.83 & 9.04 & 9.02 & 9.21 & 8.79 \\
\hline & Not specified & 0.95 & 0.67 & 0.60 & 0.99 & 1.41 & 7.62 & 1.88 & 9.44 & 7.55 \\
\hline
\end{tabular}


Table S4. (continued). Descriptive Statistics for Relevant Variables

\begin{tabular}{|c|c|c|c|c|c|c|c|c|c|c|}
\hline & Variables & Jan. & Feb. & March & April & May & June & July & Aug. & Sept. \\
\hline \multirow{10}{*}{ 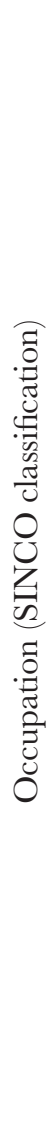 } & $\begin{array}{l}\text { Officers, direc- } \\
\text { tors, and man- } \\
\text { agers }\end{array}$ & 8.98 & 10.02 & 10.43 & 6.12 & 7.31 & 6.99 & 7.07 & 6.55 & 6.88 \\
\hline & $\begin{array}{l}\text { Professionals and } \\
\text { technicians }\end{array}$ & 40.80 & 41.82 & 41.85 & 35.07 & 41.54 & 37.92 & 39.20 & 35.76 & 36.01 \\
\hline & $\begin{array}{l}\text { Administrative } \\
\text { support staff }\end{array}$ & 11.73 & 10.71 & 10.07 & 11.35 & 9.83 & 11.44 & 11.53 & 11.92 & 12.43 \\
\hline & $\begin{array}{l}\text { Merchants, sales- } \\
\text { clerks, and sales- } \\
\text { persons }\end{array}$ & 17.78 & 17.42 & 16.32 & 22.25 & 21.95 & 21.25 & 21.01 & 22.79 & 21.91 \\
\hline & $\begin{array}{l}\text { Workers in per- } \\
\text { sonal services and } \\
\text { security }\end{array}$ & 6.77 & 4.02 & 4.55 & 5.68 & 3.33 & 4.42 & 3.96 & 4.69 & 4.20 \\
\hline & $\begin{array}{l}\text { Workers in agri- } \\
\text { culture, livestock, } \\
\text { forestry, hunting, } \\
\text { and fishing }\end{array}$ & 0.00 & 0.01 & 0.00 & 0.00 & 0.00 & 0.00 & 0.01 & 0.00 & 0.00 \\
\hline & $\begin{array}{l}\text { Handicraft work- } \\
\text { ers }\end{array}$ & 0.19 & 0.19 & 0.25 & 0.15 & 0.25 & 0.25 & 0.30 & 0.23 & 0.23 \\
\hline & $\begin{array}{l}\text { Industrial ma- } \\
\text { chine operators, } \\
\text { assemblers, and } \\
\text { drivers }\end{array}$ & 0.84 & 0.67 & 0.65 & 0.66 & 1.12 & 0.94 & 1.11 & 1.02 & 1.03 \\
\hline & General laborers & 8.72 & 11.33 & 11.92 & 16.02 & 9.90 & 12.54 & 11.34 & 13.46 & 13.29 \\
\hline & Not specified & 4.20 & 3.82 & 3.97 & 2.70 & 4.77 & 4.25 & 4.47 & 3.57 & 4.00 \\
\hline
\end{tabular}

Table S5. Effect of occupations on Wage (OLS)

\begin{tabular}{|c|c|c|c|c|c|c|c|c|}
\hline & Jan.-Feb. & March & April & May & June & July & & \\
\hline & & Officers & ectors, a & nanage & & & & \\
\hline \multirow{2}{*}{$\begin{array}{l}\text { Professionals and tech- } \\
\text { nicians }\end{array}$} & -0.12 & -0.02 & -0.20 & -0.22 & -0.14 & -0.13 & -0.14 & -0.13 \\
\hline & {$[.0088]$} & {$[.014]$} & {$[.019]$} & {$[.019]$} & {$[.016]$} & {$[.016]$} & {$[.015]$} & {$[.015]$} \\
\hline \multirow[t]{2}{*}{$\begin{array}{l}\text { Administrative support } \\
\text { staff }\end{array}$} & -0.52 & -0.46 & -0.72 & -0.73 & -0.68 & -0.64 & -0.62 & -0.65 \\
\hline & {$[.0096]$} & {$[.016]$} & {$[.019]$} & {$[.022]$} & {$[.017]$} & {$[.017]$} & {$[.016]$} & {$[.016]$} \\
\hline \multirow[t]{2}{*}{$\begin{array}{l}\text { Merchants, salesclerks, } \\
\text { and Salesperson }\end{array}$} & -0.35 & -0.26 & -0.70 & -0.54 & -0.52 & -0.46 & -0.48 & -0.49 \\
\hline & {$[.0095]$} & {$[.016]$} & {$[.019]$} & {$[.02]$} & {$[.017]$} & {$[.017]$} & {$[.016]$} & {$[.016]$} \\
\hline \multirow[t]{2}{*}{$\begin{array}{l}\text { Workers in personal } \\
\text { services and security }\end{array}$} & -0.60 & -0.47 & -0.76 & -0.56 & -0.60 & -0.63 & -0.59 & -0.64 \\
\hline & {$[.012]$} & {$[.022]$} & {$[.023]$} & [.033] & {$[.025]$} & {$[.029]$} & {$[.021]$} & [.026] \\
\hline \multirow[t]{2}{*}{$\begin{array}{l}\text { Workers in agriculture, } \\
\text { livestock, forestry, hun- } \\
\text { ting, and fishing }\end{array}$} & -0.24 & & & & & & & \\
\hline & {$[.18]$} & {$[]$.} & {$[]$.} & {$[]$.} & {$[]$.} & {$[]$.} & {$[]$.} & {$[]$.} \\
\hline \multirow[t]{2}{*}{ Handicraft workers } & 0.15 & 0.21 & 0.01 & -0.29 & -0.71 & -0.24 & -0.95 & -0.84 \\
\hline & {$[.051]$} & {$[.076]$} & {$[.073]$} & {$[.065]$} & {$[.015]$} & {$[.11]$} & {$[.014]$} & {$[.029]$} \\
\hline
\end{tabular}


Table S5. (continued). Effect of occupations on Wage (OLS)

\begin{tabular}{lcccccccc} 
& Jan.-Feb. & March & April & May & June & July & & \\
\hline $\begin{array}{l}\text { Industrial machine } \\
\text { operators, assemblers, } \\
\text { and drivers }\end{array}$ & -0.09 & 0.00 & -0.22 & -0.27 & -0.16 & -0.12 & 0.04 & -0.13 \\
& {$[.027]$} & {$[.046]$} & {$[.048]$} & {$[.048]$} & {$[.072]$} & {$[.058]$} & {$[.063]$} & {$[.055]$} \\
& -0.49 & -0.52 & -0.81 & -0.71 & -0.06 & -0.20 & -0.20 & -0.15 \\
General laborers & {$[.01]$} & {$[.016]$} & {$[.019]$} & {$[.022]$} & {$[.043]$} & {$[.038]$} & {$[.035]$} & {$[.035]$} \\
& 9.51 & 9.47 & 9.61 & 9.76 & -0.71 & -0.65 & -0.69 & -0.68 \\
Constant & {$[.008]$} & {$[.013]$} & {$[.017]$} & {$[.018]$} & {$[.017]$} & {$[.018]$} & {$[.016]$} & {$[.016]$} \\
\hline $\begin{array}{l}\text { Number of observa- } \\
\text { tions }\end{array}$ & 88279 & 32568 & 34080 & 22813 & 32813 & 32562 & 39755 & 40044 \\
\hline$R^{2}$ adjusted & 0.08 & 0.08 & 0.16 & 0.11 & 0.13 & 0.11 & 0.12 & 0.13 \\
\hline
\end{tabular}

Note: Authors' calculations. Dependent variable is $\ln ($ wage); robust standard errors shown in brackets.

Table S6. Oaxaca-Blinder equation

\begin{tabular}{|c|c|c|c|c|c|c|c|}
\hline & March & April & May & June & July & August & September \\
\hline \multicolumn{8}{|l|}{ Differential } \\
\hline & 9.29 & 9.11 & 9.36 & 9.26 & 9.29 & 9.20 & 9.21 \\
\hline \multirow[t]{2}{*}{ Current month } & {$[.002]$} & {$[.0022]$} & {$[.0023]$} & {$[.002]$} & {$[.0019]$} & {$[.0017]$} & {$[.0018]$} \\
\hline & 9.24 & 9.24 & 9.24 & 9.24 & 9.24 & 9.24 & 9.24 \\
\hline \multirow[t]{2}{*}{ January-February } & {$[.0011]$} & {$[.0011]$} & {$[.0011]$} & {$[.0011]$} & {$[.0011]$} & {$[.0011]$} & {$[.0011]$} \\
\hline & 0.04 & -0.13 & 0.12 & 0.02 & 0.05 & -0.04 & -0.03 \\
\hline $\begin{array}{l}\text { Difference between current } \\
\text { month and-Jan.-Feb. }\end{array}$ & {$[.0022]$} & {$[.0024]$} & {$[.0026]$} & {$[.0023]$} & {$[.0022]$} & {$[.002]$} & {$[.002]$} \\
\hline \multicolumn{8}{|c|}{ Decomposition } \\
\hline \multirow{3}{*}{ Explained } & 0.0137 & -0.0376 & 0.0373 & 0.0051 & 0.0221 & -0.0129 & -0.0114 \\
\hline & {$[.0021]$} & {$[.0022]$} & {$[.0024]$} & {$[.0021]$} & {$[.0021]$} & {$[.0019]$} & {$[.0019]$} \\
\hline & 0.0297 & -0.0928 & 0.0801 & 0.0122 & 0.0230 & -0.0302 & -0.0202 \\
\hline Unexplained & {$[.00041]$} & {$[.00064]$} & {$[.00054]$} & {$[.00045]$} & {$[.00037]$} & {$[.00039]$} & {$[.00038]$} \\
\hline $\begin{array}{l}\text { Number of observations in } \\
\text { current month }\end{array}$ & 32,568 & 34,081 & 22,813 & 32,813 & 32,562 & 39,755 & 40,044 \\
\hline $\begin{array}{l}\text { Number of observations in } \\
\text { Jan.-Feb. }\end{array}$ & 88,279 & 88,279 & 88,279 & 88,279 & 88,279 & 88,279 & 88,279 \\
\hline $\begin{array}{l}\text { Total number of observa- } \\
\text { tions }\end{array}$ & 120,847 & 122,360 & 111,092 & 121,092 & 120,841 & 128,034 & 128,323 \\
\hline
\end{tabular}


Table S7. Oaxaca-Blinder Full Results

\begin{tabular}{|c|c|c|c|c|c|c|c|}
\hline & March & April & May & June & July & August & September \\
\hline \multicolumn{8}{|l|}{ Differential } \\
\hline & 9.29 & 9.11 & 9.36 & 9.26 & 9.29 & 9.20 & 9.21 \\
\hline \multirow[t]{2}{*}{$\begin{array}{l}\text { Current } \\
\text { month }\end{array}$} & {$[.002]$} & {$[.0022]$} & {$[.0023]$} & {$[.002]$} & {$[.0019]$} & {$[.0017]$} & {$[.0018]$} \\
\hline & 9.24 & 9.24 & 9.24 & 9.24 & 9.24 & 9.24 & 9.24 \\
\hline \multirow[t]{2}{*}{$\begin{array}{l}\text { January-Feb- } \\
\text { ruary }\end{array}$} & {$[.0011]$} & {$[.0011]$} & {$[.0011]$} & {$[.0011]$} & {$[.0011]$} & {$[.0011]$} & {$[.0011]$} \\
\hline & 0.04 & -0.13 & 0.12 & 0.02 & 0.05 & -0.04 & -0.03 \\
\hline $\begin{array}{l}\text { Difference } \\
\text { current } \\
\text { month-JanFeb }\end{array}$ & {$[.0022]$} & {$[.0024]$} & {$[.0026]$} & {$[.0023]$} & {$[.0022]$} & {$[.002]$} & {$[.002]$} \\
\hline \multicolumn{8}{|l|}{$\begin{array}{l}\text { Decomposi- } \\
\text { tion }\end{array}$} \\
\hline \multirow{3}{*}{ Explained } & 0.0137 & -0.0376 & 0.0373 & 0.0051 & 0.0221 & -0.0129 & -0.0114 \\
\hline & {$[.0021]$} & {$[.0022]$} & {$[.0024]$} & {$[.0021]$} & {$[.0021]$} & {$[.0019]$} & {$[.0019]$} \\
\hline & 0.0297 & -0.0928 & 0.0801 & 0.0122 & 0.0230 & -0.0302 & -0.0202 \\
\hline Unexplained & {$[.00041]$} & {$[.00064]$} & {$[.00054]$} & {$[.00045]$} & {$[.00037]$} & {$[.00039]$} & {$[.00038]$} \\
\hline $\begin{array}{l}\text { Number of } \\
\text { observations } \\
\text { in current } \\
\text { month }\end{array}$ & 32568 & 34081 & 22813 & 32813 & 32562 & 39755 & 40044 \\
\hline $\begin{array}{l}\text { Number of } \\
\text { observations } \\
\text { in Jan.-Feb. }\end{array}$ & 88279 & 88279 & 88279 & 88279 & 88279 & 88279 & 88279 \\
\hline $\begin{array}{l}\text { Total number } \\
\text { of observa- } \\
\text { tions } \\
\end{array}$ & 120847 & 122360 & 111092 & 121092 & 120841 & 128034 & 128323 \\
\hline \multicolumn{8}{|l|}{ Explained } \\
\hline \multirow[t]{2}{*}{1133} & 0.00246 & -0.00131 & 0.00052 & -0.00081 & -0.00014 & -0.00233 & -0.00138 \\
\hline & {$[.0009]$} & {$[.00071]$} & {$[.00048]$} & {$[.00038]$} & {$[.00019]$} & {$[.00049]$} & {$[.00036]$} \\
\hline \multirow[t]{2}{*}{1211} & -0.00139 & -0.00384 & -0.00088 & -0.00060 & 0.00065 & -0.00145 & -0.00105 \\
\hline & {$[.00077]$} & {$[.00057]$} & {$[.00019]$} & {$[.00018]$} & {$[.0001]$} & {$[.00039]$} & {$[.00017]$} \\
\hline \multirow[t]{2}{*}{1212} & -0.00073 & -0.00208 & -0.00009 & -0.00061 & 0.00002 & -0.00211 & -0.00076 \\
\hline & {$[.00057]$} & {$[.00044]$} & {$[.00024]$} & {$[.00021]$} & [4.6e-06] & {$[.0003]$} & {$[.00019]$} \\
\hline \multirow[t]{2}{*}{1221} & 0.00003 & -0.00004 & -0.00001 & -0.00001 & 0.00000 & -0.00001 & 0.00000 \\
\hline & {$[.000051]$} & {$[.000018]$} & {$[4.3 \mathrm{e}-06]$} & {$[4.3 \mathrm{e}-06]$} & [8.0e-06] & {$[9.5 \mathrm{e}-06]$} & [8.5e-07] \\
\hline \multirow[t]{2}{*}{1223} & -0.00041 & -0.00037 & 0.00006 & -0.00015 & 0.00008 & -0.00037 & -0.00007 \\
\hline & {$[.00023]$} & {$[.00018]$} & {$[.000059]$} & {$[.000039]$} & {$[.000041]$} & {$[.00012]$} & {$[.000049]$} \\
\hline \multirow[t]{2}{*}{1224} & 0.00001 & -0.00017 & 0.00002 & 0.00001 & 0.00010 & -0.00005 & 0.00001 \\
\hline & {$[.00013]$} & {$[.00006]$} & [6.9e-06] & {$[4.3 \mathrm{e}-06]$} & {$[.000059]$} & {$[.000037]$} & [3.8e-06] \\
\hline \multirow[t]{2}{*}{1314} & 0.00878 & -0.00319 & -0.00041 & -0.00021 & 0.00006 & -0.00106 & -0.00040 \\
\hline & {$[.00066]$} & {$[.00042]$} & {$[.000083]$} & {$[.000065]$} & {$[.00022]$} & {$[.00029]$} & {$[.00011]$} \\
\hline \multirow[t]{2}{*}{1315} & 0.00049 & -0.00018 & 0.00005 & 0.00005 & 0.00001 & 0.00031 & 0.00000 \\
\hline & {$[.00042]$} & {$[.0003]$} & {$[.00015]$} & {$[.00013]$} & {$[.000014]$} & {$[.00021]$} & {$[.00012]$} \\
\hline \multirow[t]{2}{*}{1321} & -0.00001 & -0.00001 & 0.00000 & 0.00000 & 0.00000 & 0.00000 & 0.00000 \\
\hline & [8.2e-06] & {$[6.2 \mathrm{e}-06]$} & [.] & {$[]$.} & {$[4.3 \mathrm{e}-06]$} & [3.6e-06] & {$[2.9 \mathrm{e}-07]$} \\
\hline \multirow[t]{2}{*}{1322} & 0.00001 & 0.00001 & 0.00003 & 0.00001 & 0.00005 & 0.00000 & 0.00003 \\
\hline & {$[9.5 \mathrm{e}-06]$} & {$[.000024]$} & {$[.000014]$} & [8.6e-06] & {$[.000023]$} & {$[5.9 \mathrm{e}-06]$} & {$[.000013]$} \\
\hline \multirow[t]{2}{*}{1324} & 0.00019 & -0.00096 & -0.00016 & -0.00012 & 0.00000 & -0.00035 & -0.00017 \\
\hline & {$[.00033]$} & {$[.00022]$} & {$[.00012]$} & {$[.00011]$} & {$[8.7 \mathrm{e}-07]$} & {$[.00017]$} & {$[.000097]$} \\
\hline
\end{tabular}


Table S7. (continued). Oaxaca-Blinder Full Results

\begin{tabular}{|c|c|c|c|c|c|c|c|}
\hline & March & April & May & June & July & August & September \\
\hline \multirow{2}{*}{1411} & -0.00009 & -0.00038 & 0.00004 & 0.00009 & 0.00027 & -0.00023 & 0.00005 \\
\hline & {$[.00014]$} & {$[.000078]$} & {$[.000015]$} & {$[.000016]$} & {$[.000079]$} & {$[.000035]$} & {$[9.5 \mathrm{e}-06]$} \\
\hline \multirow[t]{2}{*}{1421} & -0.00054 & -0.00051 & 0.00009 & 0.00002 & 0.00017 & -0.00019 & 0.00005 \\
\hline & {$[.00014]$} & {$[.000094]$} & [.00003] & {$[.000021]$} & {$[.00012]$} & {$[.000057]$} & {$[.000022]$} \\
\hline \multirow[t]{2}{*}{1511} & 0.00026 & -0.00580 & 0.00147 & 0.00159 & 0.00516 & -0.00222 & 0.00081 \\
\hline & {$[.00058]$} & {$[.0003]$} & {$[.000096]$} & {$[.000087]$} & {$[.00037]$} & {$[.00013]$} & {$[.000055]$} \\
\hline \multirow[t]{2}{*}{1512} & 0.00002 & -0.00062 & -0.00004 & -0.00008 & 0.00011 & -0.00034 & -0.00006 \\
\hline & {$[.0002]$} & {$[.00013]$} & {$[.000049]$} & {$[.000038]$} & {$[.000039]$} & {$[.000085]$} & {$[.000034]$} \\
\hline \multirow{2}{*}{1524} & -0.00015 & -0.00026 & 0.00001 & 0.00002 & 0.00021 & -0.00015 & 0.00002 \\
\hline & {$[.000099]$} & {$[.000063]$} & [3.6e-06] & {$[5.7 \mathrm{e}-06]$} & {$[.000057]$} & {$[.000032]$} & {$[5.3 \mathrm{e}-06]$} \\
\hline \multirow{2}{*}{1611} & 0.00000 & -0.00001 & 0.00001 & -0.00001 & -0.00004 & 0.00000 & 0.00001 \\
\hline & [1.6e-06] & {$[.00001]$} & {$[.000014]$} & {$[4.5 \mathrm{e}-06]$} & {$[.000024]$} & {$[5.0 \mathrm{e}-06]$} & {$[.000014]$} \\
\hline \multirow[t]{2}{*}{1612} & 0.00000 & 0.00000 & 0.00000 & 0.00000 & 0.00000 & 0.00000 & 0.00000 \\
\hline & {$[]$.} & {$[]$.} & {$[\cdot]$} & {$[]$.} & {$[]$.} & {$[]$.} & {$[]$.} \\
\hline \multirow[t]{2}{*}{1615} & -0.00092 & -0.00123 & -0.00004 & -0.00007 & 0.00020 & -0.00073 & -0.00001 \\
\hline & [.00025] & {$[.00019]$} & {$[.000062]$} & {$[.000057]$} & {$[.000072]$} & {$[.00012]$} & {$[.000035]$} \\
\hline \multirow[t]{2}{*}{1621} & -0.00008 & -0.00171 & 0.00024 & -0.00104 & -0.00023 & -0.00222 & -0.00161 \\
\hline & [.00078] & {$[.00065]$} & {$[.00039]$} & {$[.0003]$} & {$[.000067]$} & {$[.00046]$} & {$[.00028]$} \\
\hline \multirow[t]{2}{*}{1623} & -0.00058 & -0.00039 & -0.00003 & 0.00002 & 0.00010 & -0.00013 & -0.00003 \\
\hline & [.00026] & [.0002] & {$[.000033]$} & {$[.000022]$} & {$[.00011]$} & {$[.00012]$} & {$[.000028]$} \\
\hline \multirow[t]{2}{*}{1711} & -0.00023 & 0.00012 & 0.00000 & 0.00000 & 0.00019 & 0.00002 & 0.00001 \\
\hline & [.00016] & {$[.00013]$} & [7.5e-07] & {$[5.1 \mathrm{e}-06]$} & {$[.000071]$} & {$[.000072]$} & {$[.000012]$} \\
\hline \multirow[t]{2}{*}{2111} & -0.01092 & -0.00889 & -0.00043 & -0.00033 & 0.00560 & -0.00552 & -0.00077 \\
\hline & {$[.001]$} & {$[.00075]$} & {$[.00004]$} & {$[.00003]$} & {$[.00047]$} & {$[.00041]$} & {$[.000061]$} \\
\hline \multirow[t]{2}{*}{2112} & -0.00010 & -0.00024 & 0.00049 & -0.00006 & 0.00111 & 0.00014 & -0.00004 \\
\hline & [.00037] & {$[.00024]$} & {$[.00011]$} & {$[.0001]$} & {$[.00034]$} & {$[.000091]$} & {$[.000085]$} \\
\hline \multirow[t]{2}{*}{2113} & -0.00258 & -0.00904 & 0.00078 & 0.00073 & 0.00471 & -0.00411 & 0.00055 \\
\hline & {$[.00074]$} & {$[.00046]$} & {$[.000098]$} & {$[.000073]$} & {$[.00049]$} & {$[.00023]$} & {$[.000043]$} \\
\hline \multirow[t]{2}{*}{2121} & 0.00666 & -0.00719 & -0.00025 & -0.00069 & 0.00076 & -0.00467 & -0.00132 \\
\hline & [.0012] & {$[.00081]$} & {$[.00018]$} & {$[.00016]$} & {$[.00037]$} & {$[.00051]$} & {$[.00018]$} \\
\hline \multirow[t]{2}{*}{2122} & -0.00078 & -0.00484 & -0.00057 & -0.00126 & -0.00001 & -0.00306 & -0.00168 \\
\hline & {$[.0007]$} & [.0005] & {$[.00027]$} & {$[.00025]$} & {$[2.2 \mathrm{e}-06]$} & {$[.00038]$} & {$[.00023]$} \\
\hline \multirow[t]{2}{*}{2123} & -0.00069 & -0.00061 & 0.00000 & -0.00005 & -0.00009 & -0.00024 & -0.00001 \\
\hline & {$[.0003]$} & {$[.00023]$} & {$[2.4 \mathrm{e}-06]$} & {$[.000026]$} & {$[.00013]$} & {$[.00013]$} & {$[.000022]$} \\
\hline \multirow[t]{2}{*}{2134} & 0.00026 & 0.00009 & -0.00006 & -0.00002 & -0.00011 & 0.00004 & -0.00003 \\
\hline & {$[.000089]$} & {$[.000044]$} & {$[.000029]$} & [8.7e-06] & {$[.000055]$} & {$[.00003]$} & {$[.000015]$} \\
\hline \multirow[t]{2}{*}{2135} & -0.00063 & -0.00223 & -0.00007 & -0.00014 & 0.00048 & -0.00063 & -0.00026 \\
\hline & {$[.0005]$} & {$[.00035]$} & {$[.000028]$} & {$[.000032]$} & {$[.00021]$} & {$[.00021]$} & {$[.000043]$} \\
\hline \multirow[t]{2}{*}{2142} & -0.00010 & -0.00004 & 0.00002 & 0.00000 & 0.00000 & -0.00003 & 0.00002 \\
\hline & {$[.000051]$} & {$[.00003]$} & {$[.000035]$} & {$[.000016]$} & {$[.000071]$} & {$[.000016]$} & {$[.000019]$} \\
\hline 2152 & -0.00008 & -0.00007 & 0.00010 & 0.00009 & 0.00019 & -0.00001 & 0.00011 \\
\hline & {$[.000037]$} & {$[.000014]$} & {$[.000031]$} & {$[.000029]$} & {$[.000062]$} & [4.6e-06] & {$[.000026]$} \\
\hline 2153 & 0.00021 & -0.00008 & 0.00002 & 0.00011 & 0.00002 & 0.00000 & -0.00003 \\
\hline & {$[.00012]$} & {$[.000052]$} & {$[.000052]$} & {$[.000063]$} & {$[.000016]$} & {$[.000063]$} & {$[.000031]$} \\
\hline 2161 & 0.00000 & 0.00000 & 0.00000 & 0.00000 & 0.00000 & 0.00000 & -0.00007 \\
\hline & {$[]$.} & {$[]$.} & {$[]$.} & {$[]$.} & {$[]$.} & {$[]$.} & {$[.000048]$} \\
\hline 2162 & 0.00002 & -0.00003 & 0.00000 & 0.00000 & 0.00003 & -0.00001 & 0.00000 \\
\hline & {$[.000028]$} & {$[.000012]$} & {$[2.2 \mathrm{e}-06]$} & {$[1.7 \mathrm{e}-06]$} & {$[.000011]$} & [6.2e-06] & [1.1e-06] \\
\hline 2164 & 0.00000 & -0.00005 & -0.00003 & -0.00003 & -0.00001 & -0.00004 & -0.00003 \\
\hline
\end{tabular}


Table S7. (continued). Oaxaca-Blinder Full Results

\begin{tabular}{|c|c|c|c|c|c|c|c|}
\hline & March & April & May & June & July & August & September \\
\hline & {$[.000043]$} & {$[.000027]$} & {$[.000016]$} & {$[.000016]$} & {$[8.4 \mathrm{e}-06]$} & {$[.000022]$} & {$[.000016]$} \\
\hline \multirow[t]{2}{*}{2172} & 0.00000 & -0.00001 & 0.00002 & 0.00002 & 0.00003 & 0.00000 & 0.00001 \\
\hline & {$[.000012]$} & {$[3.4 \mathrm{e}-06]$} & [8.9e-06] & [8.9e-06] & {$[.000017]$} & [1.3e-06] & {$[.000012]$} \\
\hline \multirow[t]{2}{*}{2211} & -0.00008 & 0.00012 & -0.00006 & 0.00002 & -0.00001 & -0.00002 & -0.00005 \\
\hline & {$[.00012]$} & {$[.00013]$} & {$[.000032]$} & {$[.000064]$} & {$[.000015]$} & {$[.000079]$} & {$[.000038]$} \\
\hline \multirow[t]{2}{*}{2212} & -0.00043 & -0.00095 & -0.00011 & -0.00027 & 0.00006 & -0.00065 & -0.00034 \\
\hline & {$[.00025]$} & {$[.00017]$} & {$[.000077]$} & {$[.000057]$} & {$[.000019]$} & {$[.00011]$} & {$[.000074]$} \\
\hline \multirow[t]{2}{*}{2221} & 0.00000 & 0.00000 & 0.00000 & 0.00000 & 0.00000 & 0.00000 & 0.00000 \\
\hline & {$[]$.} & {$[]$.} & {$[]$.} & {$[]$.} & {$[]$.} & {$[]$.} & {$[]$.} \\
\hline \multirow[t]{2}{*}{2222} & -0.00037 & -0.00101 & 0.00009 & 0.00006 & 0.00059 & -0.00046 & 0.00010 \\
\hline & {$[.00024]$} & {$[.00013]$} & {$[.000026]$} & {$[.000031]$} & {$[.00014]$} & {$[.000071]$} & {$[.000025]$} \\
\hline \multirow[t]{2}{*}{2231} & 0.00009 & 0.00045 & 0.00023 & 0.00042 & -0.00006 & 0.00038 & 0.00016 \\
\hline & {$[.00017]$} & {$[.00018]$} & {$[.000082]$} & {$[.000094]$} & {$[.000018]$} & {$[.00012]$} & {$[.000063]$} \\
\hline \multirow[t]{2}{*}{2232} & 0.00010 & 0.00000 & 0.00000 & -0.00001 & -0.00015 & -0.00001 & 0.00000 \\
\hline & {$[.00013]$} & {$[.000088]$} & {$[4.2 \mathrm{e}-06]$} & {$[.000015]$} & {$[.000077]$} & {$[.000049]$} & [4.1e-06] \\
\hline \multirow[t]{2}{*}{2233} & -0.00011 & 0.00018 & 0.00010 & 0.00001 & -0.00002 & -0.00001 & 0.00007 \\
\hline & {$[.00015]$} & {$[.00013]$} & {$[.000056]$} & {$[.000033]$} & {$[.000019]$} & {$[.000075]$} & {$[.000033]$} \\
\hline \multirow[t]{2}{*}{2241} & 0.00001 & -0.00080 & -0.00007 & -0.00006 & 0.00006 & -0.00045 & -0.00008 \\
\hline & {$[.00028]$} & {$[.00019]$} & {$[.000056]$} & {$[.000047]$} & {$[.000069]$} & {$[.00013]$} & {$[.000052]$} \\
\hline \multirow[t]{2}{*}{2242} & -0.00009 & -0.00141 & -0.00011 & -0.00015 & 0.00003 & -0.00062 & -0.00013 \\
\hline & {$[.00044]$} & {$[.0003]$} & {$[.000077]$} & {$[.000063]$} & {$[.00012]$} & {$[.00019]$} & {$[.000079]$} \\
\hline \multirow[t]{2}{*}{2251} & 0.00061 & -0.00089 & 0.00002 & 0.00010 & -0.00020 & 0.00024 & -0.00005 \\
\hline & {$[.00035]$} & {$[.00021]$} & {$[.000052]$} & {$[.000045]$} & {$[.00012]$} & {$[.00016]$} & {$[.000042]$} \\
\hline \multirow[t]{2}{*}{2252} & -0.00059 & -0.00129 & -0.00054 & -0.00008 & 0.00019 & 0.00029 & 0.00008 \\
\hline & {$[.00057]$} & {$[.00039]$} & {$[.000091]$} & {$[.000097]$} & {$[.00013]$} & {$[.00028]$} & {$[.00013]$} \\
\hline \multirow[t]{2}{*}{2253} & 0.00013 & -0.00176 & -0.00027 & -0.00018 & -0.00002 & 0.00041 & -0.00002 \\
\hline & {$[.0007]$} & {$[.00051]$} & [.00017] & {$[.00015]$} & {$[.00013]$} & {$[.00038]$} & {$[.00016]$} \\
\hline \multirow[t]{2}{*}{2254} & -0.00025 & 0.00005 & 0.00000 & -0.00009 & -0.00001 & -0.00016 & 0.00005 \\
\hline & {$[.00012]$} & {$[.00014]$} & {$[.000063]$} & {$[.000044]$} & {$[8.2 \mathrm{e}-06]$} & {$[.000081]$} & {$[.000062]$} \\
\hline \multirow[t]{2}{*}{2261} & 0.00032 & 0.00075 & 0.00053 & 0.00053 & 0.00003 & 0.00110 & 0.00003 \\
\hline & {$[.00035]$} & {$[.00032]$} & [.00017] & {$[.00014]$} & {$[.000013]$} & {$[.00026]$} & {$[.00011]$} \\
\hline \multirow[t]{2}{*}{2263} & 0.00020 & -0.00089 & -0.00004 & -0.00001 & 0.00009 & -0.00001 & -0.00014 \\
\hline & {$[.00034]$} & {$[.00023]$} & {$[.000068]$} & {$[.000059]$} & {$[.000061]$} & {$[.00016]$} & {$[.000062]$} \\
\hline \multirow[t]{2}{*}{2271} & 0.01022 & 0.00690 & 0.00630 & 0.00230 & 0.00210 & 0.00198 & 0.00055 \\
\hline & {$[.0018]$} & {$[.0016]$} & {$[.00099]$} & {$[.00081]$} & {$[.00034]$} & {$[.0011]$} & [.00077] \\
\hline \multirow[t]{2}{*}{2272} & 0.00147 & 0.00173 & 0.00396 & 0.00260 & 0.00162 & 0.00161 & 0.00097 \\
\hline & {$[.0008]$} & {$[.00075]$} & {$[.00053]$} & {$[.00045]$} & {$[.0002]$} & {$[.00057]$} & {$[.0004]$} \\
\hline \multirow[t]{2}{*}{2281} & 0.00019 & -0.00003 & 0.00017 & 0.00001 & -0.00008 & -0.00016 & 0.00009 \\
\hline & {$[.0002]$} & {$[.00014]$} & {$[.000077]$} & {$[.000036]$} & {$[.000064]$} & {$[.000075]$} & {$[.00005]$} \\
\hline \multirow[t]{2}{*}{2312} & 0.00005 & -0.00003 & 0.00008 & 0.00000 & 0.00015 & 0.00001 & 0.00014 \\
\hline & {$[.000042]$} & {$[.000011]$} & {$[.000046]$} & {$[.000057]$} & {$[.000077]$} & {$[.000013]$} & [.000033] \\
\hline 2331 & 0.00000 & 0.00000 & 0.00001 & 0.00001 & 0.00001 & 0.00000 & 0.00001 \\
\hline & [2.1e-06] & {$[]$.} & {$[6.2 \mathrm{e}-06]$} & {$[6.2 \mathrm{e}-06]$} & {$[.00001]$} & [2.6e-06] & {$[5.9 \mathrm{e}-06]$} \\
\hline 2332 & 0.00006 & 0.00000 & 0.00001 & 0.00001 & 0.00002 & 0.00001 & 0.00001 \\
\hline & {$[.000026]$} & {$[4.2 \mathrm{e}-14]$} & [8.7e-06] & {$[8.7 \mathrm{e}-06]$} & {$[.000015]$} & {$[3.7 \mathrm{e}-06]$} & [8.3e-06] \\
\hline 2339 & 0.00000 & 0.00006 & -0.00019 & -0.00009 & -0.00078 & 0.00006 & -0.00027 \\
\hline & {$[]$.} & {$[.000029]$} & {$[.000043]$} & {$[.000022]$} & {$[.00012]$} & {$[.000011]$} & [.000049] \\
\hline 2343 & 0.00000 & -0.00002 & 0.00007 & 0.00005 & 0.00008 & 0.00001 & 0.00004 \\
\hline & {$[.000032]$} & {$[.00001]$} & {$[.000016]$} & {$[.000018]$} & [.000048] & {$[4.4 \mathrm{e}-06]$} & [.00002] \\
\hline
\end{tabular}


Table S7. (continued). Oaxaca-Blinder Full Results

\begin{tabular}{|c|c|c|c|c|c|c|c|}
\hline & March & April & May & June & July & August & September \\
\hline \multirow[t]{2}{*}{2391} & 0.00004 & 0.00003 & 0.00002 & 0.00002 & 0.00008 & 0.00003 & 0.00003 \\
\hline & {$[.0001]$} & {$[.000049]$} & {$[.000025]$} & {$[.000019]$} & {$[.000076]$} & {$[.000053]$} & {$[.000021]$} \\
\hline \multirow[t]{2}{*}{2411} & 0.00111 & 0.00443 & -0.00206 & -0.00057 & -0.00378 & 0.00192 & -0.00006 \\
\hline & [.00042] & {$[.00041]$} & [.00012] & {$[.000047]$} & {$[.00033]$} & {$[.00019]$} & {$[7.0 \mathrm{e}-06]$} \\
\hline \multirow[t]{2}{*}{2412} & 0.00025 & 0.00114 & 0.00139 & 0.00167 & -0.00096 & 0.00177 & 0.00115 \\
\hline & {$[.00025]$} & {$[.00027]$} & {$[.00014]$} & {$[.00014]$} & {$[.000073]$} & {$[.0002]$} & [.00013] \\
\hline \multirow[t]{2}{*}{2413} & 0.00005 & -0.00003 & -0.00001 & 0.00014 & 0.00029 & 0.00000 & 0.00008 \\
\hline & {$[.00014]$} & {$[.000074]$} & {$[.000084]$} & {$[.000064]$} & {$[.00016]$} & [3.6e-06] & {$[.000058]$} \\
\hline \multirow[t]{2}{*}{2421} & 0.00003 & 0.00002 & -0.00003 & -0.00003 & 0.00000 & -0.00003 & 0.00000 \\
\hline & {$[.000086]$} & {$[.000056]$} & {$[.000012]$} & {$[.000012]$} & {$[1.0 \mathrm{e}-06]$} & {$[.000027]$} & {$[.000025]$} \\
\hline \multirow[t]{2}{*}{2422} & 0.00023 & 0.00003 & -0.00003 & 0.00002 & -0.00010 & 0.00001 & 0.00006 \\
\hline & {$[.000087]$} & {$[.000037]$} & {$[.000056]$} & [.000042] & {$[.00012]$} & {$[5.4 \mathrm{e}-06]$} & {$[.000035]$} \\
\hline \multirow[t]{2}{*}{2423} & 0.00007 & 0.00003 & -0.00004 & -0.00005 & -0.00008 & 0.00000 & 0.00003 \\
\hline & {$[.00011]$} & {$[.000077]$} & {$[.000034]$} & {$[.000045]$} & {$[.00012]$} & {$[.000017]$} & {$[.000034]$} \\
\hline \multirow[t]{2}{*}{2424} & 0.00000 & 0.00072 & 0.00045 & 0.00079 & 0.00025 & 0.00073 & 0.00080 \\
\hline & {$[]$.} & {$[.00016]$} & {$[.000078]$} & {$[.000095]$} & {$[.00003]$} & {$[.0001]$} & {$[.000096]$} \\
\hline \multirow[t]{2}{*}{2425} & 0.00000 & 0.00000 & 0.00001 & 0.00000 & -0.00006 & 0.00003 & 0.00000 \\
\hline & {$[]$.} & {$[]$.} & {$[.00001]$} & {$[]$.} & {$[.00003]$} & {$[.000021]$} & [1.1e-07] \\
\hline \multirow[t]{2}{*}{2426} & 0.00137 & 0.00162 & -0.00285 & -0.00327 & -0.00494 & -0.00033 & -0.00123 \\
\hline & [.00019] & {$[.00015]$} & [.00029] & {$[.00025]$} & {$[.00046]$} & {$[.00003]$} & {$[.00016]$} \\
\hline \multirow[t]{2}{*}{2427} & 0.00003 & -0.00002 & 0.00010 & 0.00010 & 0.00009 & 0.00001 & 0.00006 \\
\hline & {$[.00005]$} & {$[.000025]$} & {$[.000031]$} & {$[.000026]$} & {$[.000078]$} & {$[2.7 \mathrm{e}-06]$} & {$[.000029]$} \\
\hline \multirow[t]{2}{*}{2428} & -0.00002 & -0.00043 & -0.00009 & 0.00013 & -0.00023 & -0.00033 & 0.00003 \\
\hline & {$[.00039]$} & {$[.00028]$} & {$[.000076]$} & {$[.000055]$} & {$[.0003]$} & {$[.00013]$} & {$[.000031]$} \\
\hline \multirow[t]{2}{*}{2511} & -0.00008 & -0.00352 & 0.00019 & 0.00010 & -0.00071 & 0.00067 & 0.00015 \\
\hline & {$[.0006]$} & {$[.0004]$} & [.000088] & {$[.000081]$} & {$[.00022]$} & {$[.00031]$} & {$[.000084]$} \\
\hline \multirow[t]{2}{*}{2512} & -0.00022 & -0.00177 & -0.00003 & -0.00012 & 0.00047 & -0.00057 & -0.00013 \\
\hline & {$[.00033]$} & {$[.00019]$} & [.000019] & {$[.000018]$} & {$[.00013]$} & {$[.00013]$} & {$[.000024]$} \\
\hline \multirow[t]{2}{*}{2522} & -0.00020 & -0.00038 & -0.00002 & -0.00002 & 0.00002 & -0.00015 & 0.00001 \\
\hline & {$[.00015]$} & {$[.0001]$} & [.000013] & {$[.000014]$} & {$[.000065]$} & {$[.000063]$} & {$[.000025]$} \\
\hline \multirow[t]{2}{*}{2523} & 0.00001 & -0.00154 & -0.00017 & -0.00037 & 0.00001 & -0.00118 & -0.00048 \\
\hline & [.00049] & {$[.00035]$} & [.00019] & {$[.00016]$} & {$[3.2 \mathrm{e}-06]$} & {$[.00025]$} & {$[.00015]$} \\
\hline \multirow[t]{2}{*}{2531} & 0.00000 & 0.00001 & 0.00003 & -0.00004 & -0.00010 & 0.00000 & 0.00000 \\
\hline & {$[]$.} & {$[.000013]$} & [.000019] & {$[.000031]$} & {$[.000055]$} & {$[3.7 \mathrm{e}-06]$} & {$[]$.} \\
\hline \multirow[t]{2}{*}{2532} & 0.00007 & -0.00020 & -0.00005 & -0.00005 & 0.00000 & -0.00003 & 0.00000 \\
\hline & {$[.00014]$} & {$[.000075]$} & {$[.000012]$} & {$[.000015]$} & {$[.000042]$} & {$[.000052]$} & {$[.000014]$} \\
\hline \multirow[t]{2}{*}{2542} & -0.00016 & -0.00002 & 0.00002 & 0.00001 & -0.00007 & 0.00005 & -0.00005 \\
\hline & {$[.00015]$} & {$[.000099]$} & {$[.000014]$} & {$[.000019]$} & {$[.00011]$} & {$[.000035]$} & {$[.00003]$} \\
\hline \multirow[t]{2}{*}{2543} & -0.00002 & -0.00109 & 0.00046 & 0.00046 & 0.00099 & -0.00017 & 0.00032 \\
\hline & {$[.0002]$} & {$[.0001]$} & {$[.000096]$} & {$[.000075]$} & {$[.00022]$} & {$[.000025]$} & {$[.00007]$} \\
\hline 2544 & 0.00001 & -0.00001 & -0.00016 & -0.00003 & -0.00006 & 0.00004 & -0.00004 \\
\hline & {$[.00013]$} & {$[.000078]$} & {$[.000083]$} & {$[.000047]$} & {$[.00014]$} & {$[.000018]$} & {$[.000042]$} \\
\hline 2552 & 0.00049 & -0.00006 & 0.00103 & 0.00093 & 0.00207 & 0.00013 & 0.00079 \\
\hline & {$[.000082]$} & {$[.000013]$} & [.000093] & {$[.000091]$} & {$[.00018]$} & {$[.000013]$} & {$[.000091]$} \\
\hline 2614 & -0.00018 & 0.00001 & 0.00051 & 0.00053 & 0.00095 & 0.00025 & 0.00051 \\
\hline & {$[.00002]$} & [1.0e-06] & {$[.000073]$} & {$[.000067]$} & {$[.00011]$} & {$[.000027]$} & {$[.000062]$} \\
\hline 2621 & 0.00115 & -0.00004 & 0.00016 & 0.00020 & -0.00038 & 0.00115 & 0.00044 \\
\hline & {$[.00069]$} & [.00054] & {$[.00017]$} & {$[.00014]$} & {$[.00014]$} & {$[.00035]$} & {$[.00014]$} \\
\hline 2630 & 0.00010 & -0.00036 & -0.00001 & -0.00002 & 0.00005 & 0.00010 & -0.00002 \\
\hline
\end{tabular}


Table S7. (continued). Oaxaca-Blinder Full Results

\begin{tabular}{|c|c|c|c|c|c|c|c|}
\hline & March & April & May & June & July & August & September \\
\hline & {$[.00018]$} & {$[.00011]$} & {$[.000044]$} & {$[.000041]$} & {$[.000039]$} & [.000099] & {$[.000043]$} \\
\hline \multirow[t]{2}{*}{2631} & -0.00003 & -0.00019 & -0.00017 & -0.00013 & 0.00001 & -0.00015 & -0.00012 \\
\hline & {$[.00016]$} & {$[.0001]$} & {$[.000026]$} & {$[.000034]$} & [3.8e-06] & {$[.000054]$} & {$[.000042]$} \\
\hline \multirow[t]{2}{*}{2632} & -0.00010 & -0.00037 & -0.00012 & -0.00002 & 0.00001 & -0.00004 & 0.00011 \\
\hline & {$[.00015]$} & {$[.000088]$} & {$[.000048]$} & {$[.000056]$} & [5.5e-06] & [.000092] & {$[.000064]$} \\
\hline \multirow[t]{2}{*}{2634} & -0.00004 & -0.00016 & 0.00007 & 0.00001 & -0.00009 & 0.00010 & 0.00005 \\
\hline & {$[.00017]$} & {$[.00012]$} & {$[.000035]$} & {$[.000039]$} & {$[.000054]$} & {$[.0001]$} & {$[.00004]$} \\
\hline \multirow[t]{2}{*}{2640} & -0.00003 & -0.00002 & -0.00001 & 0.00000 & 0.00000 & -0.00002 & 0.00003 \\
\hline & {$[.000018]$} & {$[.000015]$} & [6.8e-06] & [.000012] & [7.1e-07] & {$[.000012]$} & {$[.000025]$} \\
\hline \multirow[t]{2}{*}{2641} & 0.00028 & 0.00006 & -0.00017 & 0.00002 & 0.00002 & 0.00004 & 0.00001 \\
\hline & {$[.0002]$} & {$[.00012]$} & {$[.000067]$} & {$[.00005]$} & {$[.00015]$} & {$[.000043]$} & {$[.000024]$} \\
\hline \multirow[t]{2}{*}{2643} & 0.00003 & -0.00041 & 0.00014 & 0.00006 & 0.00016 & -0.00014 & 0.00001 \\
\hline & [.00017] & {$[.00009]$} & {$[.000037]$} & [.000029] & {$[.00011]$} & {$[.000048]$} & {$[9.7 \mathrm{e}-06]$} \\
\hline \multirow[t]{2}{*}{2644} & 0.00004 & 0.00014 & 0.00042 & 0.00042 & 0.00062 & 0.00026 & 0.00041 \\
\hline & {$[6.7 \mathrm{e}-06]$} & {$[.000021]$} & {$[.000062]$} & {$[.000062]$} & {$[.000091]$} & {$[.000038]$} & {$[.00006]$} \\
\hline \multirow[t]{2}{*}{2651} & 0.00185 & 0.00042 & 0.00137 & -0.00020 & 0.00024 & -0.00214 & -0.00040 \\
\hline & {$[.00095]$} & {$[.00077]$} & {$[.00023]$} & {$[.00019]$} & {$[.00019]$} & {$[.00043]$} & {$[.0002]$} \\
\hline \multirow[t]{2}{*}{2652} & -0.00073 & -0.00085 & 0.00401 & 0.00803 & 0.01507 & 0.00223 & 0.00717 \\
\hline & {$[.00035]$} & {$[.00013]$} & {$[.0006]$} & {$[.00048]$} & {$[.00089]$} & {$[.00013]$} & {$[.00043]$} \\
\hline \multirow[t]{2}{*}{2653} & -0.00018 & -0.00028 & -0.00001 & -0.00004 & 0.00005 & -0.00005 & -0.00004 \\
\hline & {$[.0001]$} & {$[.000068]$} & {$[7.5 \mathrm{e}-06]$} & [9.9e-06] & {$[.00004]$} & {$[.000053]$} & {$[.000016]$} \\
\hline \multirow[t]{2}{*}{2654} & 0.00000 & 0.00006 & 0.00000 & 0.00000 & -0.00008 & -0.00001 & -0.00003 \\
\hline & {$[.000018]$} & {$[.000036]$} & {$[9.9 \mathrm{e}-06]$} & {$[.000015]$} & {$[.00004]$} & {$[.000014]$} & {$[.000012]$} \\
\hline \multirow[t]{2}{*}{2655} & 0.00002 & 0.00000 & -0.00002 & -0.00001 & -0.00002 & 0.00000 & 0.00001 \\
\hline & {$[.000026]$} & {$[.000018]$} & [.00002] & {$[.000019]$} & {$[.00005]$} & {$[5.3 \mathrm{e}-07]$} & {$[.000023]$} \\
\hline \multirow[t]{2}{*}{2714} & -0.00003 & -0.00022 & 0.00005 & -0.00006 & 0.00022 & -0.00001 & 0.00008 \\
\hline & {$[.00013]$} & {$[.000057]$} & {$[.000072]$} & {$[.000058]$} & {$[.00014]$} & [8.5e-06] & {$[.000046]$} \\
\hline \multirow[t]{2}{*}{2716} & 0.00005 & 0.00001 & 0.00033 & 0.00049 & 0.00071 & 0.00017 & 0.00023 \\
\hline & {$[.000014]$} & {$[1.4 \mathrm{e}-06]$} & {$[.000097]$} & {$[.000061]$} & {$[.00012]$} & {$[.000031]$} & {$[.000078]$} \\
\hline \multirow[t]{2}{*}{2811} & -0.00004 & -0.00004 & -0.00001 & 0.00001 & 0.00010 & 0.00000 & 0.00004 \\
\hline & {$[.000025]$} & {$[9.9 \mathrm{e}-06]$} & {$[.000035]$} & {$[.000028]$} & {$[.000028]$} & [3.6e-07] & {$[.000011]$} \\
\hline \multirow[t]{2}{*}{2812} & 0.00000 & 0.00024 & 0.00008 & 0.00001 & -0.00022 & 0.00011 & 0.00001 \\
\hline & {$[]$.} & {$[.000086]$} & {$[.000018]$} & [2.8e-06] & {$[.000052]$} & {$[.000025]$} & [1.6e-06] \\
\hline \multirow[t]{2}{*}{2813} & 0.00062 & -0.00003 & -0.00025 & -0.00018 & -0.00075 & -0.00004 & 0.00018 \\
\hline & {$[.00014]$} & {$[.000064]$} & {$[.00017]$} & {$[.00012]$} & {$[.00028]$} & {$[.000015]$} & {$[.000087]$} \\
\hline \multirow[t]{2}{*}{2821} & 0.00000 & 0.00011 & -0.00017 & -0.00015 & -0.00027 & 0.00008 & -0.00002 \\
\hline & {$[]$.} & {$[.000043]$} & {$[.000036]$} & {$[.000037]$} & {$[.000064]$} & {$[.000024]$} & [6.7e-06] \\
\hline \multirow[t]{2}{*}{2822} & -0.00003 & -0.00010 & 0.00000 & 0.00001 & 0.00003 & -0.00004 & 0.00000 \\
\hline & {$[.000057]$} & {$[.000023]$} & {$[5.3 \mathrm{e}-06]$} & [2.6e-06] & {$[.000029]$} & {$[.000017]$} & [4.3e-07] \\
\hline \multirow[t]{2}{*}{3111} & -0.00040 & -0.00009 & 0.00052 & 0.00009 & 0.00045 & -0.00002 & 0.00014 \\
\hline & {$[.00011]$} & {$[.000066]$} & {$[.00011]$} & {$[.00013]$} & {$[.00025]$} & [.000016] & {$[.00011]$} \\
\hline 3113 & 0.00035 & -0.00088 & 0.00011 & -0.00026 & 0.00010 & -0.00095 & -0.00048 \\
\hline & {$[.00055]$} & [.00045] & {$[.00026]$} & {$[.00023]$} & {$[.000074]$} & {$[.00033]$} & {$[.00022]$} \\
\hline 3115 & -0.00188 & -0.00004 & 0.00400 & -0.00039 & 0.00182 & 0.00068 & -0.00063 \\
\hline & {$[.00015]$} & {$[.00002]$} & {$[.00067]$} & {$[.00064]$} & {$[.001]$} & {$[.00025]$} & {$[.00057]$} \\
\hline 3122 & -0.00023 & -0.00161 & 0.00342 & 0.00246 & 0.00427 & -0.00011 & 0.00179 \\
\hline & {$[.00054]$} & [.0003] & {$[.00038]$} & {$[.00035]$} & {$[.0008]$} & {$[.00003]$} & {$[.00028]$} \\
\hline 3131 & 0.00012 & 0.00000 & 0.00049 & 0.00051 & 0.00054 & 0.00017 & 0.00033 \\
\hline & {$[.000047]$} & [2.1e-06] & {$[.00011]$} & {$[.0001]$} & [.0002] & {$[.000042]$} & {$[.0001]$} \\
\hline
\end{tabular}


Table S7. (continued). Oaxaca-Blinder Full Results

\begin{tabular}{|c|c|c|c|c|c|c|c|}
\hline & March & April & May & June & July & August & September \\
\hline \multirow[t]{2}{*}{3132} & 0.00067 & 0.00150 & -0.00087 & -0.00252 & -0.00573 & 0.00008 & -0.00390 \\
\hline & [.00049] & {$[.00028]$} & {$[.00037]$} & {$[.00034]$} & {$[.00079]$} & [8.7e-06] & {$[.00034]$} \\
\hline \multirow[t]{2}{*}{3142} & 0.00000 & 0.00000 & -0.00002 & -0.00003 & 0.00001 & 0.00008 & 0.00001 \\
\hline & {$[]$.} & {$[]$.} & {$[.000021]$} & [9.5e-06] & [2.8e-06] & {$[.000046]$} & [3.1e-06] \\
\hline \multirow[t]{2}{*}{3211} & -0.00037 & -0.00017 & 0.00257 & 0.00215 & 0.00399 & 0.00058 & 0.00155 \\
\hline & {$[.00015]$} & {$[.000034]$} & {$[.00025]$} & {$[.00025]$} & {$[.00043]$} & {$[.000086]$} & {$[.00023]$} \\
\hline \multirow[t]{2}{*}{3212} & 0.00000 & 0.00115 & -0.00344 & -0.00259 & -0.00701 & 0.00006 & -0.00312 \\
\hline & {$[]$.} & [.00012] & [.00023] & {$[.00016]$} & {$[.00041]$} & {$[3.0 \mathrm{e}-06]$} & {$[.00016]$} \\
\hline \multirow[t]{2}{*}{3221} & -0.00014 & -0.00023 & 0.00036 & 0.00042 & 0.00074 & 0.00005 & 0.00020 \\
\hline & {$[.000086]$} & {$[.000027]$} & {$[.000054]$} & {$[.000047]$} & {$[.00011]$} & {$[7.4 \mathrm{e}-06]$} & {$[.000057]$} \\
\hline \multirow[t]{2}{*}{3222} & -0.00015 & -0.00035 & -0.00002 & -0.00005 & 0.00020 & -0.00021 & -0.00004 \\
\hline & {$[.0001]$} & {$[.000056]$} & {$[3.0 \mathrm{e}-06]$} & {$[.00001]$} & [.000033] & {$[.000033]$} & {$[5.9 \mathrm{e}-06]$} \\
\hline \multirow[t]{2}{*}{4111} & -0.00026 & -0.00057 & 0.00015 & -0.00011 & -0.00001 & -0.00003 & -0.00013 \\
\hline & {$[.00043]$} & {$[.00031]$} & [.00018] & {$[.00015]$} & [6.5e-06] & {$[.00025]$} & {$[.00015]$} \\
\hline \multirow[t]{2}{*}{4201} & 0.00092 & -0.00148 & 0.00067 & 0.00058 & 0.00235 & -0.00014 & -0.00003 \\
\hline & {$[.00049]$} & [.00027] & [.00022] & {$[.00021]$} & {$[.00052]$} & {$[.00007]$} & [.00018] \\
\hline \multirow[t]{2}{*}{4211} & -0.00001 & 0.00026 & -0.00083 & -0.00028 & -0.00135 & -0.00011 & -0.00071 \\
\hline & {$[.00001]$} & {$[.000067]$} & {$[.000095]$} & {$[.000039]$} & {$[.00017]$} & {$[.000011]$} & {$[.000066]$} \\
\hline \multirow[t]{2}{*}{4213} & -0.00060 & -0.00043 & 0.00324 & 0.00294 & 0.00599 & 0.00108 & 0.00259 \\
\hline & {$[.00017]$} & {$[.000036]$} & [.00039] & {$[.00034]$} & {$[.0006]$} & {$[.00011]$} & [.00032] \\
\hline \multirow[t]{2}{*}{4221} & -0.00540 & 0.02232 & -0.00823 & -0.00834 & -0.02714 & 0.01071 & -0.00732 \\
\hline & [.0013] & [.00083] & [.00039] & {$[.00037]$} & {$[.0012]$} & {$[.00037]$} & [.00029] \\
\hline \multirow[t]{2}{*}{4222} & -0.00029 & -0.00142 & -0.00011 & -0.00020 & 0.00032 & -0.00074 & -0.00029 \\
\hline & {$[.00031]$} & {$[.0002]$} & {$[.000042]$} & {$[.000034]$} & {$[.000088]$} & {$[.00012]$} & {$[.000041]$} \\
\hline \multirow[t]{2}{*}{4231} & -0.00053 & 0.00015 & 0.00394 & 0.00402 & 0.00675 & 0.00160 & 0.00322 \\
\hline & {$[.00009]$} & {$[.000015]$} & {$[.00031]$} & {$[.00027]$} & {$[.00045]$} & {$[.00012]$} & {$[.00027]$} \\
\hline \multirow[t]{2}{*}{4999} & -0.00017 & -0.00030 & 0.00056 & 0.00013 & 0.00013 & 0.00014 & -0.00005 \\
\hline & {$[.00027]$} & {$[.00021]$} & {$[.0002]$} & {$[.00017]$} & {$[.000065]$} & {$[.00019]$} & [.00012] \\
\hline \multirow[t]{2}{*}{5101} & -0.00038 & -0.00055 & -0.00003 & -0.00005 & 0.00025 & -0.00018 & -0.00004 \\
\hline & {$[.00016]$} & {$[.00011]$} & [6.6e-06] & {$[9.7 \mathrm{e}-06]$} & {$[.000065]$} & {$[.000062]$} & {$[.00001]$} \\
\hline \multirow[t]{2}{*}{5111} & -0.00101 & 0.00015 & 0.00135 & 0.00102 & 0.00312 & 0.00017 & 0.00028 \\
\hline & {$[.00015]$} & {$[.000032]$} & [.00017] & {$[.00017]$} & [.0003] & {$[.000054]$} & {$[.0002]$} \\
\hline \multirow[t]{2}{*}{5112} & 0.00000 & -0.00004 & 0.00006 & 0.00006 & 0.00011 & 0.00000 & 0.00006 \\
\hline & {$[.000034]$} & {$[.000011]$} & {$[.000015]$} & {$[.000015]$} & {$[.00004]$} & [3.9e-08] & [.000013] \\
\hline \multirow[t]{2}{*}{5113} & 0.00077 & -0.00074 & 0.00036 & 0.00038 & 0.00089 & -0.00008 & 0.00025 \\
\hline & {$[.00022]$} & {$[.000076]$} & {$[.000061]$} & {$[.000056]$} & {$[.00015]$} & {$[.000015]$} & {$[.000048]$} \\
\hline \multirow[t]{2}{*}{5115} & -0.00008 & -0.00016 & 0.00000 & 0.00000 & -0.00009 & -0.00001 & -0.00001 \\
\hline & {$[.00011]$} & {$[.000062]$} & {$[5.5 \mathrm{e}-07]$} & {$[3.4 \mathrm{e}-06]$} & {$[.000074]$} & {$[.000041]$} & [7.6e-06] \\
\hline \multirow[t]{2}{*}{5201} & 0.00001 & -0.00002 & 0.00026 & 0.00015 & 0.00009 & 0.00003 & 0.00003 \\
\hline & {$[.000051]$} & {$[.000011]$} & {$[.000042]$} & {$[.000062]$} & [.00012] & {$[.000021]$} & {$[.000058]$} \\
\hline 5211 & -0.00005 & 0.00000 & 0.00019 & -0.00001 & 0.00025 & 0.00004 & 0.00011 \\
\hline & {$[.000016]$} & {$[.000011]$} & {$[.000054]$} & {$[.000071]$} & {$[.000094]$} & {$[.000024]$} & {$[.000052]$} \\
\hline 5212 & 0.00028 & -0.00030 & -0.00119 & -0.00123 & -0.00357 & -0.00034 & 0.00083 \\
\hline & {$[.000061]$} & {$[.000035]$} & {$[.00038]$} & [.00032] & {$[.00059]$} & {$[.00013]$} & {$[.00022]$} \\
\hline 5213 & -0.00001 & -0.00001 & 0.00004 & 0.00002 & 0.00005 & 0.00002 & 0.00004 \\
\hline & {$[.000012]$} & {$[2.4 \mathrm{e}-06]$} & {$[.000027]$} & {$[.000037]$} & {$[.000048]$} & [6.2e-06] & {$[.000019]$} \\
\hline 5254 & 0.00000 & 0.00000 & -0.00001 & -0.00001 & 0.00001 & -0.00001 & -0.00003 \\
\hline & {$[3.5 \mathrm{e}-06]$} & {$[5.5 \mathrm{e}-06]$} & {$[.000037]$} & {$[.000027]$} & {$[.000054]$} & {$[.000014]$} & {$[.000032]$} \\
\hline 5311 & 0.00000 & 0.00000 & -0.00004 & -0.00002 & -0.00003 & 0.00000 & -0.00005 \\
\hline
\end{tabular}


Table S7. (continued). Oaxaca-Blinder Full Results

\begin{tabular}{|c|c|c|c|c|c|c|c|}
\hline & March & April & May & June & July & August & September \\
\hline & {$[4.5 \mathrm{e}-06]$} & {$[3.0 \mathrm{e}-07]$} & [.000033] & {$[.000018]$} & {$[.00005]$} & {$[2.5 \mathrm{e}-06]$} & {$[.000025]$} \\
\hline \multirow[t]{2}{*}{5313} & 0.00135 & 0.00154 & 0.00054 & -0.00250 & -0.00064 & -0.00080 & -0.00156 \\
\hline & {$[.00021]$} & {$[.0001]$} & {$[.0003]$} & [.00033] & {$[.00054]$} & {$[.000077]$} & {$[.00028]$} \\
\hline \multirow[t]{2}{*}{5314} & 0.00045 & -0.00012 & 0.00005 & -0.00002 & -0.00024 & 0.00008 & 0.00000 \\
\hline & {$[.00018]$} & {$[.00011]$} & {$[.000014]$} & {$[.000011]$} & {$[.000097]$} & {$[.000065]$} & {$[1.7 \mathrm{e}-06]$} \\
\hline \multirow[t]{2}{*}{5411} & -0.00001 & -0.00001 & 0.00000 & 0.00000 & 0.00000 & -0.00001 & 0.00000 \\
\hline & {$[.000013]$} & {$[.00001]$} & [4.3e-06] & {$[4.3 \mathrm{e}-06]$} & {$[]$.} & [7.8e-06] & [4.6e-06] \\
\hline \multirow[t]{2}{*}{5413} & 0.00103 & 0.00054 & 0.00081 & 0.00045 & -0.00009 & -0.00023 & -0.00068 \\
\hline & {$[.00055]$} & [.00049] & {$[.0003]$} & {$[.00027]$} & {$[.000096]$} & {$[.00034]$} & {$[.00021]$} \\
\hline \multirow{2}{*}{5999} & -0.00159 & 0.00154 & 0.01220 & 0.00908 & 0.01385 & 0.00399 & 0.00737 \\
\hline & {$[.000054]$} & {$[.00005]$} & {$[.0004]$} & {$[.00044]$} & {$[.00073]$} & {$[.0002]$} & [.00042] \\
\hline \multirow{2}{*}{6116} & -0.00002 & -0.00002 & 0.00000 & 0.00000 & -0.00001 & 0.00000 & 0.00000 \\
\hline & {$[.000013]$} & [9.3e-06] & [1.3e-06] & {$[5.7 \mathrm{e}-06]$} & {$[.000019]$} & [3.0e-06] & {$[9.9 \mathrm{e}-06]$} \\
\hline \multirow[t]{2}{*}{7214} & 0.00066 & -0.00037 & 0.00016 & 0.00017 & -0.00014 & 0.00031 & 0.00015 \\
\hline & {$[.00033]$} & {$[.00023]$} & [.000092] & {$[.000082]$} & {$[.00004]$} & {$[.00018]$} & {$[.000081]$} \\
\hline \multirow[t]{2}{*}{8101} & -0.00064 & -0.00129 & -0.00010 & 0.00002 & -0.00004 & 0.00013 & 0.00006 \\
\hline & {$[.00043]$} & {$[.00031]$} & {$[.00011]$} & {$[.000097]$} & {$[.00011]$} & {$[.00022]$} & {$[.0001]$} \\
\hline \multirow[t]{2}{*}{8131} & 0.00010 & -0.00001 & 0.00000 & 0.00001 & -0.00044 & 0.00005 & -0.00001 \\
\hline & {$[.000097]$} & {$[.00007]$} & {$[.000027]$} & {$[.000033]$} & {$[.0001]$} & {$[.000023]$} & {$[4.4 \mathrm{e}-06]$} \\
\hline \multirow[t]{2}{*}{8132} & -0.00004 & -0.00003 & 0.00000 & 0.00001 & 0.00002 & -0.00002 & 0.00000 \\
\hline & {$[.000044]$} & {$[.000033]$} & {$[2.8 \mathrm{e}-06]$} & {$[6.2 \mathrm{e}-06]$} & {$[.000023]$} & {$[.000021]$} & {$[3.2 \mathrm{e}-06]$} \\
\hline \multirow[t]{2}{*}{8133} & 0.00008 & 0.00001 & 0.00003 & 0.00003 & 0.00001 & 0.00003 & 0.00001 \\
\hline & {$[.000066]$} & {$[.000034]$} & {$[.000026]$} & {$[.000028]$} & [7.6e-06] & {$[.000025]$} & {$[.000018]$} \\
\hline \multirow[t]{2}{*}{8135} & 0.00000 & 0.00036 & 0.00028 & 0.00086 & 0.00020 & 0.00036 & 0.00051 \\
\hline & {$[]$.} & {$[.00013]$} & {$[.000087]$} & {$[.00017]$} & {$[.000046]$} & {$[.000092]$} & {$[.000099]$} \\
\hline \multirow[t]{2}{*}{8142} & 0.00000 & 0.00000 & 0.00000 & -0.00001 & 0.00000 & 0.00005 & 0.00003 \\
\hline & {$[]$.} & {$[]$.} & {$[\cdot]$} & {$[9.2 \mathrm{e}-06]$} & {$[]$.} & {$[.000054]$} & {$[.000034]$} \\
\hline \multirow[t]{2}{*}{8144} & -0.00004 & -0.00005 & 0.00000 & -0.00001 & 0.00000 & -0.00001 & 0.00000 \\
\hline & {$[.000042]$} & {$[.000019]$} & {$[1.4 \mathrm{e}-07]$} & {$[3.7 \mathrm{e}-06]$} & {$[.000012]$} & {$[.000017]$} & {$[2.0 \mathrm{e}-06]$} \\
\hline \multirow[t]{2}{*}{8153} & -0.00002 & -0.00001 & 0.00000 & 0.00000 & 0.00001 & -0.00001 & 0.00000 \\
\hline & {$[.000011]$} & [8.6e-06] & [1.5e-07] & [1.5e-07] & {$[6.2 \mathrm{e}-06]$} & {$[4.9 \mathrm{e}-06]$} & [2.6e-07] \\
\hline \multirow[t]{2}{*}{8154} & -0.00003 & -0.00002 & -0.00001 & -0.00001 & 0.00000 & -0.00002 & 0.00000 \\
\hline & {$[.00002]$} & {$[.000017]$} & {$[8.0 \mathrm{e}-06]$} & [8.0e-06] & {$[1.9 \mathrm{e}-06]$} & [.000013] & {$[.000011]$} \\
\hline \multirow[t]{2}{*}{8161} & -0.00015 & 0.00008 & 0.00005 & 0.00000 & -0.00005 & 0.00001 & 0.00000 \\
\hline & {$[.000047]$} & {$[.000071]$} & {$[.000034]$} & [7.2e-07] & {$[.000031]$} & {$[.000054]$} & {$[2.0 \mathrm{e}-07]$} \\
\hline \multirow[t]{2}{*}{8211} & -0.00020 & -0.00002 & 0.00019 & 0.00002 & 0.00032 & -0.00003 & 0.00005 \\
\hline & {$[.00004]$} & {$[.000023]$} & {$[.000067]$} & {$[.000076]$} & {$[.00013]$} & {$[.000024]$} & {$[.000072]$} \\
\hline \multirow[t]{2}{*}{8323} & 0.00000 & 0.00006 & 0.00024 & 0.00002 & -0.00007 & 0.00008 & 0.00002 \\
\hline & {$[]$.} & {$[.000043]$} & {$[.000098]$} & {$[.000011]$} & {$[.000024]$} & {$[.000035]$} & [8.6e-06] \\
\hline \multirow[t]{2}{*}{8341} & 0.00005 & 0.00030 & -0.00030 & -0.00002 & -0.00058 & 0.00042 & -0.00005 \\
\hline & {$[.000063]$} & {$[.000098]$} & {$[.000055]$} & [5.7e-06] & [.000092] & {$[.000077]$} & [8.5e-06] \\
\hline 8342 & 0.00000 & 0.00006 & -0.00118 & -0.00006 & -0.00020 & 0.00003 & 0.00000 \\
\hline & {$[]$.} & {$[.000046]$} & {$[.00017]$} & {$[.000019]$} & {$[.000056]$} & [8.9e-06] & {$[1.4 \mathrm{e}-06]$} \\
\hline 9231 & 0.00141 & 0.00045 & 0.00001 & 0.00000 & -0.00128 & 0.00108 & 0.00018 \\
\hline & [.00042] & {$[.00028]$} & {$[.000012]$} & [1.7e-07] & [.00022] & {$[.00017]$} & {$[.000023]$} \\
\hline 9232 & 0.00107 & -0.00008 & -0.00034 & -0.00833 & -0.00683 & -0.00564 & -0.00974 \\
\hline & [.00012] & [3.0e-06] & {$[.00038]$} & {$[.0005]$} & {$[.00071]$} & {$[.00024]$} & {$[.00048]$} \\
\hline 9233 & 0.00002 & 0.00007 & 0.00000 & -0.00002 & -0.00013 & 0.00002 & 0.00000 \\
\hline & {$[.000064]$} & {$[.00006]$} & [1.3e-06] & {$[.000012]$} & {$[.000058]$} & {$[.000026]$} & {$[4.0 \mathrm{e}-06]$} \\
\hline
\end{tabular}


Table S7. (continued). Oaxaca-Blinder Full Results

\begin{tabular}{|c|c|c|c|c|c|c|c|}
\hline & March & April & May & June & July & August & September \\
\hline \multirow[t]{2}{*}{9235} & -0.00002 & -0.00004 & -0.00001 & -0.00001 & 0.00000 & -0.00001 & 0.00000 \\
\hline & {$[.000027]$} & {$[.000017]$} & {$[3.4 \mathrm{e}-06]$} & [3.4e-06] & {$[.000017]$} & {$[.000016]$} & [8.8e-07] \\
\hline \multirow[t]{2}{*}{9236} & 0.00007 & 0.00004 & 0.00001 & 0.00000 & -0.00008 & 0.00011 & 0.00002 \\
\hline & {$[.00014]$} & [.00013] & {$[.000014]$} & {$[.000013]$} & {$[.000061]$} & {$[.000084]$} & {$[.000022]$} \\
\hline \multirow[t]{2}{*}{9239} & 0.00019 & 0.00060 & -0.00023 & -0.00003 & -0.00077 & -0.00025 & 0.00025 \\
\hline & [.00029] & {$[.0002]$} & {$[.00016]$} & [.00012] & {$[.00036]$} & {$[.000052]$} & {$[.000091]$} \\
\hline \multirow[t]{2}{*}{9331} & 0.00342 & 0.00380 & -0.00160 & -0.00300 & -0.00412 & 0.00074 & -0.00288 \\
\hline & {$[.00057]$} & {$[.00034]$} & [.0003] & {$[.0003]$} & {$[.00067]$} & {$[.000063]$} & [.00023] \\
\hline \multirow[t]{2}{*}{9411} & 0.00023 & -0.00054 & 0.00126 & 0.00080 & 0.00254 & -0.00028 & -0.00033 \\
\hline & {$[.000019]$} & {$[.000068]$} & {$[.00028]$} & [.00027] & {$[.00039]$} & {$[.00015]$} & [.00029] \\
\hline \multirow[t]{2}{*}{9512} & -0.00080 & 0.00008 & 0.00175 & 0.00114 & 0.00145 & 0.00013 & 0.00046 \\
\hline & {$[.00048]$} & {$[.00026]$} & {$[.00046]$} & [.00042] & {$[.0009]$} & {$[.000037]$} & [.00037] \\
\hline \multirow[t]{2}{*}{9521} & 0.00025 & -0.00013 & 0.00001 & 0.00003 & -0.00003 & -0.00009 & 0.00001 \\
\hline & {$[.00019]$} & {$[.00012]$} & {$[.00001]$} & {$[.000023]$} & {$[.000076]$} & {$[.00007]$} & {$[.000025]$} \\
\hline \multirow[t]{2}{*}{9601} & -0.00005 & 0.00001 & 0.00009 & 0.00009 & 0.00015 & 0.00004 & 0.00009 \\
\hline & {$[.000016]$} & [1.8e-06] & {$[.000025]$} & {$[.000025]$} & {$[.000041]$} & {$[.000011]$} & {$[.000024]$} \\
\hline \multirow[t]{2}{*}{9621} & 0.00000 & -0.00001 & -0.00046 & -0.00077 & -0.00118 & 0.00012 & -0.00037 \\
\hline & {$[]$.} & {$[4.9 \mathrm{e}-06]$} & {$[.00012]$} & {$[.00013]$} & {$[.00019]$} & {$[.000026]$} & {$[.000079]$} \\
\hline \multirow[t]{2}{*}{9622} & 0.00000 & -0.00250 & 0.00101 & -0.00182 & -0.00019 & -0.00204 & -0.00267 \\
\hline & [5.1e-07] & {$[.00015]$} & {$[.00027]$} & {$[.00036]$} & {$[.00045]$} & {$[.00022]$} & {$[.00036]$} \\
\hline \multirow[t]{2}{*}{9641} & 0.00001 & -0.00001 & 0.00013 & 0.00009 & 0.00018 & 0.00004 & 0.00007 \\
\hline & {$[.000014]$} & {$[4.4 \mathrm{e}-06]$} & {$[.000027]$} & {$[.00004]$} & {$[.00005]$} & {$[.00002]$} & {$[.000042]$} \\
\hline \multirow[t]{2}{*}{9722} & 0.00002 & -0.00007 & -0.00019 & -0.00035 & -0.00004 & -0.00008 & -0.00027 \\
\hline & {$[.000071]$} & {$[.000016]$} & {$[.00027]$} & {$[.00024]$} & {$[.0004]$} & {$[.000096]$} & {$[.0002]$} \\
\hline \multicolumn{8}{|c|}{ Unexplained } \\
\hline \multirow[t]{2}{*}{1133} & -0.00010 & 0.00565 & 0.01135 & 0.00144 & 0.00280 & -0.00100 & 0.00197 \\
\hline & {$[.00034]$} & {$[.00019]$} & {$[.00088]$} & {$[.00017]$} & {$[.00045]$} & {$[.00018]$} & {$[.00017]$} \\
\hline \multirow[t]{2}{*}{1211} & 0.00138 & 0.00796 & 0.01471 & 0.00260 & 0.00132 & -0.00491 & 0.00237 \\
\hline & {$[.00046]$} & {$[.00019]$} & {$[.001]$} & {$[.00023]$} & {$[.00054]$} & {$[.00034]$} & {$[.0002]$} \\
\hline \multirow[t]{2}{*}{1212} & 0.00012 & 0.00399 & 0.00972 & 0.00244 & 0.00117 & -0.00032 & 0.00192 \\
\hline & [.00032] & {$[.00014]$} & {$[.00083]$} & [.00022] & {$[.00038]$} & {$[.00015]$} & {$[.00017]$} \\
\hline \multirow[t]{2}{*}{1221} & -0.00003 & 0.00002 & -0.00001 & -0.00001 & 0.00003 & -0.00004 & -0.00004 \\
\hline & {$[.000038]$} & {$[.00001]$} & [3.5e-06] & [3.5e-06] & {$[.000042]$} & {$[.000041]$} & [.00002] \\
\hline \multirow[t]{2}{*}{1223} & 0.00058 & 0.00111 & 0.00294 & 0.00023 & 0.00059 & 0.00009 & 0.00054 \\
\hline & {$[.00013]$} & {$[.000077]$} & {$[.00045]$} & {$[.000078]$} & {$[.00022]$} & {$[.000063]$} & [.00009] \\
\hline \multirow[t]{2}{*}{1224} & 0.00019 & 0.00023 & 0.00024 & 0.00003 & -0.00006 & -0.00013 & 0.00003 \\
\hline & {$[.000075]$} & {$[.000033]$} & {$[.00014]$} & {$[.000036]$} & {$[.000087]$} & {$[.000058]$} & [.00003] \\
\hline \multirow[t]{2}{*}{1314} & -0.01665 & 0.00689 & 0.01629 & 0.00330 & 0.00587 & -0.00246 & 0.00625 \\
\hline & {$[.00078]$} & {$[.00017]$} & {$[.0011]$} & {$[.00025]$} & {$[.00063]$} & {$[.00027]$} & [.00031] \\
\hline 1315 & -0.00015 & 0.00097 & 0.00473 & 0.00068 & 0.00083 & -0.00254 & 0.00071 \\
\hline & {$[.00023]$} & {$[.000076]$} & {$[.00057]$} & {$[.00011]$} & {$[.00027]$} & {$[.00023]$} & {$[.0001]$} \\
\hline 1321 & 0.00001 & 0.00000 & 0.00000 & 0.00000 & -0.00001 & 0.00000 & 0.00000 \\
\hline & [6.7e-06] & {$[4.6 \mathrm{e}-06]$} & {$[1.6 \mathrm{e}-06]$} & [1.6e-06] & {$[5.8 \mathrm{e}-06]$} & {$[2.0 \mathrm{e}-06]$} & {$[1.3 \mathrm{e}-06]$} \\
\hline 1322 & -0.00003 & 0.00011 & -0.00001 & 0.00007 & -0.00003 & 0.00005 & -0.00001 \\
\hline & {$[.000037]$} & {$[.000043]$} & [3.5e-06] & {$[.00006]$} & {$[.000013]$} & {$[.000019]$} & {$[2.9 \mathrm{e}-06]$} \\
\hline 1324 & -0.00011 & 0.00121 & 0.00261 & 0.00077 & 0.00067 & -0.00039 & 0.00049 \\
\hline & {$[.00018]$} & {$[.000084]$} & {$[.00045]$} & {$[.00012]$} & {$[.00023]$} & {$[.0001]$} & {$[.000086]$} \\
\hline 1411 & -0.00005 & 0.00054 & 0.00075 & -0.00019 & -0.00007 & 0.00006 & -0.00003 \\
\hline & {$[.00014]$} & {$[.000049]$} & {$[.00024]$} & {$[.000021]$} & {$[.00014]$} & {$[.000051]$} & {$[.000034]$} \\
\hline
\end{tabular}


Table S7. (continued). Oaxaca-Blinder Full Results

\begin{tabular}{|c|c|c|c|c|c|c|c|}
\hline & March & April & May & June & July & August & September \\
\hline \multirow{2}{*}{1421} & 0.00045 & 0.00085 & 0.00123 & 0.00048 & 0.00044 & -0.00005 & 0.00025 \\
\hline & {$[.00014]$} & {$[.000062]$} & {$[.0003]$} & {$[.000094]$} & {$[.00021]$} & {$[.000076]$} & {$[.000067]$} \\
\hline \multirow[t]{2}{*}{1511} & 0.00043 & 0.01030 & 0.01018 & -0.00015 & -0.00174 & -0.00137 & 0.00318 \\
\hline & {$[.00055]$} & {$[.00022]$} & [.0009] & {$[.00018]$} & {$[.00054]$} & {$[.00028]$} & {$[.00025]$} \\
\hline \multirow[t]{2}{*}{1512} & -0.00021 & 0.00086 & 0.00165 & 0.00030 & 0.00010 & -0.00002 & 0.00021 \\
\hline & {$[.00016]$} & {$[.000082]$} & {$[.00035]$} & {$[.000081]$} & {$[.00016]$} & {$[.000061]$} & {$[.00006]$} \\
\hline \multirow[t]{2}{*}{1524} & 0.00016 & 0.00044 & 0.00049 & 0.00009 & -0.00019 & 0.00014 & 0.00004 \\
\hline & {$[.000085]$} & {$[.000062]$} & {$[.00021]$} & {$[.00005]$} & {$[.000077]$} & {$[.000021]$} & {$[.000036]$} \\
\hline \multirow{2}{*}{1611} & 0.00001 & 0.00002 & 0.00000 & 0.00007 & 0.00012 & 0.00001 & 0.00000 \\
\hline & {$[.000013]$} & {$[.000014]$} & [1.6e-06] & {$[.00004]$} & {$[.000064]$} & {$[.000011]$} & {$[1.3 \mathrm{e}-06]$} \\
\hline \multirow[t]{2}{*}{1612} & 0.00000 & 0.00000 & 0.00000 & 0.00000 & 0.00000 & 0.00000 & 0.00001 \\
\hline & {$[]$.} & {$[]$.} & {$[]$.} & {$[]$.} & {$[]$.} & {$[]$.} & {$[9.4 \mathrm{e}-06]$} \\
\hline \multirow[t]{2}{*}{1615} & 0.00081 & 0.00201 & 0.00391 & 0.00107 & 0.00048 & 0.00024 & 0.00048 \\
\hline & {$[.00016]$} & {$[.00013]$} & {$[.00054]$} & {$[.00014]$} & {$[.00025]$} & {$[.000069]$} & {$[.000087]$} \\
\hline \multirow[t]{2}{*}{1621} & -0.00016 & 0.00614 & 0.01377 & 0.00155 & 0.00076 & -0.00109 & 0.00180 \\
\hline & {$[.00038]$} & {$[.00018]$} & [.00098] & [.00018] & {$[.00041]$} & [.0002] & {$[.00017]$} \\
\hline \multirow[t]{2}{*}{1623} & 0.00046 & 0.00146 & 0.00387 & 0.00069 & 0.00063 & -0.00102 & 0.00074 \\
\hline & [.0002] & {$[.00008]$} & [.00053] & {$[.00011]$} & {$[.00026]$} & {$[.00015]$} & {$[.0001]$} \\
\hline \multirow[t]{2}{*}{1711} & 0.00025 & 0.00057 & 0.00198 & 0.00026 & 0.00014 & -0.00050 & 0.00060 \\
\hline & [.00012] & {$[.00005]$} & {$[.00037]$} & {$[.000067]$} & {$[.00017]$} & {$[.0001]$} & [.000089] \\
\hline \multirow[t]{2}{*}{2111} & 0.01121 & 0.02609 & 0.04909 & 0.00649 & 0.00489 & -0.01156 & 0.00992 \\
\hline & {$[.00076]$} & {$[.00033]$} & [.0018] & {$[.00039]$} & {$[.00098]$} & {$[.00055]$} & {$[.0004]$} \\
\hline \multirow[t]{2}{*}{2112} & -0.00027 & 0.00426 & 0.00887 & 0.00242 & 0.00110 & -0.00513 & 0.00277 \\
\hline & {$[.0004]$} & {$[.00014]$} & {$[.00078]$} & {$[.0002]$} & {$[.00044]$} & {$[.00032]$} & {$[.0002]$} \\
\hline \multirow[t]{2}{*}{2113} & 0.00290 & 0.01962 & 0.03327 & 0.00647 & 0.00382 & -0.00104 & 0.00751 \\
\hline & {$[.00068]$} & {$[.00032]$} & {$[.0015]$} & {$[.00037]$} & {$[.00081]$} & {$[.00032]$} & {$[.00035]$} \\
\hline \multirow[t]{2}{*}{2121} & -0.00592 & 0.02167 & 0.05351 & 0.00823 & 0.00708 & -0.00894 & 0.00994 \\
\hline & {$[.00086]$} & [.0003] & [.0019] & {$[.00039]$} & [.0009] & {$[.00048]$} & [.00038] \\
\hline \multirow[t]{2}{*}{2122} & -0.00069 & 0.00517 & 0.01095 & 0.00272 & 0.00115 & -0.00063 & 0.00211 \\
\hline & {$[.00042]$} & {$[.00015]$} & [.00086] & {$[.00024]$} & {$[.00045]$} & {$[.00019]$} & [.00019] \\
\hline \multirow[t]{2}{*}{2123} & 0.00005 & 0.00196 & 0.00440 & 0.00114 & 0.00250 & -0.00142 & 0.00109 \\
\hline & {$[.00026]$} & {$[.000092]$} & [.00053] & {$[.00015]$} & {$[.00038]$} & {$[.00018]$} & {$[.00013]$} \\
\hline \multirow[t]{2}{*}{2134} & -0.00012 & 0.00011 & 0.00049 & 0.00015 & 0.00024 & 0.00002 & 0.00011 \\
\hline & {$[.000061]$} & {$[.000025]$} & [.00018] & {$[.000047]$} & {$[.000089]$} & {$[.000021]$} & {$[.000035]$} \\
\hline \multirow[t]{2}{*}{2135} & 0.00116 & 0.00623 & 0.01169 & 0.00241 & 0.00266 & -0.00191 & 0.00268 \\
\hline & {$[.00036]$} & {$[.00018]$} & {$[.00091]$} & {$[.00022]$} & {$[.00049]$} & {$[.00023]$} & {$[.00021]$} \\
\hline \multirow[t]{2}{*}{2142} & 0.00014 & 0.00013 & 0.00033 & 0.00024 & 0.00017 & 0.00007 & 0.00009 \\
\hline & {$[.000054]$} & {$[.000025]$} & {$[.00015]$} & {$[.000068]$} & {$[.0001]$} & {$[.000021]$} & {$[.000038]$} \\
\hline \multirow[t]{2}{*}{2152} & 0.00010 & 0.00015 & 0.00008 & 0.00001 & -0.00005 & 0.00007 & -0.00004 \\
\hline & {$[.000064]$} & {$[.000027]$} & {$[.000092]$} & {$[.000031]$} & {$[.000078]$} & {$[.00002]$} & {$[.000012]$} \\
\hline 2153 & -0.00013 & 0.00007 & 0.00021 & 0.00011 & 0.00011 & 0.00002 & 0.00003 \\
\hline & {$[.000064]$} & {$[.000024]$} & {$[.00012]$} & [.000039] & {$[.000066]$} & {$[.000014]$} & {$[.000024]$} \\
\hline 2161 & 0.00000 & 0.00000 & 0.00000 & 0.00000 & 0.00000 & 0.00000 & 0.00002 \\
\hline & {$[]$.} & {$[]$.} & {$[]$.} & {$[]$.} & {$[]$.} & {$[]$.} & {$[.000013]$} \\
\hline 2162 & -0.00006 & 0.00002 & 0.00006 & -0.00001 & -0.00003 & 0.00001 & -0.00001 \\
\hline & {$[.000049]$} & {$[.00001]$} & {$[.000066]$} & [3.5e-06] & {$[.000013]$} & {$[4.4 \mathrm{e}-06]$} & {$[2.9 \mathrm{e}-06]$} \\
\hline 2164 & -0.00004 & 0.00001 & 0.00000 & 0.00000 & -0.00002 & 0.00001 & 0.00000 \\
\hline & {$[.000051]$} & [7.9e-06] & {$[2.7 \mathrm{e}-06]$} & {$[2.7 \mathrm{e}-06]$} & {$[.00001]$} & [3.4e-06] & {$[2.2 \mathrm{e}-06]$} \\
\hline 2172 & -0.00002 & 0.00002 & -0.00001 & -0.00001 & -0.00002 & -0.00003 & 0.00000 \\
\hline
\end{tabular}


Table S7. (continued). Oaxaca-Blinder Full Results

\begin{tabular}{|c|c|c|c|c|c|c|c|}
\hline & March & April & May & June & July & August & September \\
\hline & {$[.000035]$} & {$[9.2 \mathrm{e}-06]$} & [3.1e-06] & [3.1e-06] & {$[.000012]$} & {$[.000022]$} & [9.6e-06] \\
\hline \multirow[t]{2}{*}{2211} & 0.00011 & 0.00023 & -0.00001 & 0.00018 & 0.00008 & -0.00003 & 0.00001 \\
\hline & {$[.000042]$} & {$[.00004]$} & {$[.000035]$} & {$[.000059]$} & {$[.000082]$} & [.000032] & {$[.000019]$} \\
\hline \multirow[t]{2}{*}{2212} & 0.00039 & 0.00096 & 0.00175 & 0.00010 & 0.00014 & 0.00004 & 0.00057 \\
\hline & {$[.00014]$} & {$[.000073]$} & {$[.00035]$} & {$[.000065]$} & {$[.00018]$} & {$[.000065]$} & {$[.00011]$} \\
\hline \multirow[t]{2}{*}{2221} & -0.00002 & 0.00000 & 0.00000 & 0.00000 & 0.00000 & 0.00000 & 0.00000 \\
\hline & {$[.000019]$} & {$[]$.} & {$[]$.} & {$[]$.} & {$[]$.} & {$[]$.} & {$[]$.} \\
\hline \multirow{2}{*}{2222} & 0.00102 & 0.00162 & 0.00305 & 0.00056 & 0.00028 & 0.00014 & 0.00036 \\
\hline & [.00018] & {$[.000087]$} & [.00048] & {$[.00011]$} & {$[.00025]$} & {$[.000085]$} & {$[.000086]$} \\
\hline \multirow[t]{2}{*}{2231} & -0.00007 & 0.00038 & 0.00159 & 0.00054 & 0.00059 & -0.00054 & 0.00028 \\
\hline & {$[.000096]$} & {$[.000043]$} & [.00032] & {$[.000082]$} & {$[.00015]$} & {$[.000095]$} & {$[.000057]$} \\
\hline \multirow[t]{2}{*}{2232} & 0.00002 & 0.00039 & 0.00151 & 0.00012 & 0.00072 & -0.00012 & 0.00025 \\
\hline & {$[.0001]$} & {$[.000042]$} & {$[.00033]$} & {$[.000046]$} & {$[.00018]$} & {$[.000059]$} & {$[.000058]$} \\
\hline \multirow[t]{2}{*}{2233} & 0.00007 & 0.00011 & 0.00130 & 0.00002 & 0.00034 & -0.00032 & 0.00013 \\
\hline & {$[.000087]$} & {$[.000032]$} & {$[.00029]$} & {$[.000032]$} & {$[.00013]$} & {$[.000083]$} & {$[.000044]$} \\
\hline \multirow[t]{2}{*}{2241} & -0.00010 & 0.00141 & 0.00297 & 0.00052 & 0.00079 & -0.00015 & 0.00070 \\
\hline & {$[.0002]$} & {$[.000084]$} & {$[.00046]$} & {$[.0001]$} & {$[.00025]$} & {$[.000094]$} & {$[.0001]$} \\
\hline \multirow[t]{2}{*}{2242} & 0.00089 & 0.00337 & 0.00731 & 0.00125 & 0.00207 & -0.00123 & 0.00204 \\
\hline & [.00027] & {$[.00013]$} & {$[.00072]$} & {$[.00016]$} & {$[.00039]$} & {$[.00018]$} & {$[.00017]$} \\
\hline \multirow[t]{2}{*}{2251} & -0.00039 & 0.00166 & 0.00529 & 0.00124 & 0.00160 & -0.00138 & 0.00090 \\
\hline & [.00025] & {$[.000086]$} & {$[.00061]$} & {$[.00014]$} & {$[.00031]$} & {$[.00017]$} & [.0001 1] \\
\hline \multirow[t]{2}{*}{2252} & 0.00229 & 0.00396 & 0.00671 & 0.00191 & 0.00210 & -0.00354 & 0.00374 \\
\hline & {$[.0003]$} & {$[.00013]$} & {$[.0007]$} & {$[.00019]$} & {$[.00044]$} & {$[.00027]$} & {$[.00023]$} \\
\hline \multirow[t]{2}{*}{2253} & 0.00020 & 0.00576 & 0.01473 & 0.00230 & 0.00340 & -0.00467 & 0.00350 \\
\hline & {$[.00043]$} & {$[.00016]$} & {$[.001]$} & {$[.00021]$} & {$[.00053]$} & {$[.00031]$} & {$[.00022]$} \\
\hline \multirow[t]{2}{*}{2254} & 0.00015 & 0.00026 & 0.00044 & -0.00001 & -0.00003 & 0.00003 & 0.00014 \\
\hline & {$[.000056]$} & {$[.000037]$} & {$[.00017]$} & {$[.000021]$} & {$[.000074]$} & {$[.000026]$} & {$[.000042]$} \\
\hline \multirow[t]{2}{*}{2261} & 0.00003 & 0.00130 & 0.00424 & 0.00064 & 0.00114 & -0.00112 & 0.00035 \\
\hline & {$[.00017]$} & {$[.000081]$} & {$[.00053]$} & {$[.000094]$} & {$[.00024]$} & {$[.00014]$} & {$[.000073]$} \\
\hline \multirow[t]{2}{*}{2263} & 0.00003 & 0.00148 & 0.00292 & 0.00013 & 0.00034 & -0.00144 & 0.00027 \\
\hline & [.00021] & {$[.000083]$} & {$[.00043]$} & {$[.000074]$} & {$[.00023]$} & {$[.00017]$} & {$[.000076]$} \\
\hline \multirow[t]{2}{*}{2271} & -0.00468 & 0.02059 & 0.06429 & 0.00683 & 0.01893 & -0.02008 & 0.01062 \\
\hline & {$[.00081]$} & {$[.00029]$} & {$[.002]$} & {$[.00035]$} & {$[.001]$} & {$[.00063]$} & {$[.00038]$} \\
\hline \multirow[t]{2}{*}{2272} & -0.00136 & 0.00686 & 0.02246 & 0.00612 & 0.01063 & -0.00195 & 0.00579 \\
\hline & {$[.0004]$} & [.0002] & {$[.0012]$} & {$[.00031]$} & {$[.00066]$} & {$[.00022]$} & {$[.00029]$} \\
\hline \multirow[t]{2}{*}{2281} & 0.00016 & 0.00068 & 0.00298 & 0.00052 & 0.00052 & 0.00001 & 0.00080 \\
\hline & {$[.00011]$} & {$[.000063]$} & {$[.00048]$} & {$[.000097]$} & {$[.00017]$} & {$[.000051]$} & {$[.00011]$} \\
\hline \multirow[t]{2}{*}{2312} & -0.00012 & 0.00019 & 0.00037 & 0.00010 & 0.00010 & -0.00008 & 0.00000 \\
\hline & {$[.000092]$} & {$[.00003]$} & {$[.00018]$} & {$[.000041]$} & {$[.00011]$} & {$[.000047]$} & {$[.000024]$} \\
\hline \multirow[t]{2}{*}{2331} & 0.00001 & 0.00000 & 0.00000 & 0.00000 & -0.00001 & 0.00000 & 0.00000 \\
\hline & {$[6.7 \mathrm{e}-06]$} & {$[4.6 \mathrm{e}-06]$} & [1.6e-06] & [1.6e-06] & [5.8e-06] & {$[2.0 \mathrm{e}-06]$} & [1.3e-06] \\
\hline 2332 & -0.00009 & 0.00001 & 0.00000 & 0.00000 & -0.00001 & 0.00000 & 0.00000 \\
\hline & {$[.000043]$} & [6.5e-06] & {$[2.2 \mathrm{e}-06]$} & {$[2.2 \mathrm{e}-06]$} & [8.3e-06] & [2.8e-06] & [1.8e-06] \\
\hline 2339 & 0.00000 & 0.00000 & 0.00121 & 0.00019 & 0.00104 & -0.00045 & 0.00029 \\
\hline & {$[]$.} & {$[2.1 \mathrm{e}-06]$} & {$[.00027]$} & {$[.000043]$} & {$[.00016]$} & {$[.000079]$} & {$[.000052]$} \\
\hline 2343 & -0.00005 & 0.00005 & -0.00003 & 0.00000 & 0.00000 & -0.00003 & 0.00000 \\
\hline & {$[.000066]$} & {$[.000023]$} & {$[6.7 \mathrm{e}-06]$} & {$[.000026]$} & {$[.00006]$} & {$[.000036]$} & {$[.000017]$} \\
\hline 2391 & 0.00004 & 0.00008 & 0.00061 & 0.00011 & 0.00009 & 0.00007 & 0.00004 \\
\hline & {$[.00009]$} & {$[.000035]$} & {$[.00021]$} & {$[.000049]$} & {$[.00011]$} & {$[.00004]$} & {$[.000033]$} \\
\hline
\end{tabular}


Table S7. (continued). Oaxaca-Blinder Full Results

\begin{tabular}{|c|c|c|c|c|c|c|c|}
\hline & March & April & May & June & July & August & September \\
\hline \multirow[t]{2}{*}{2411} & -0.00058 & 0.00633 & 0.03518 & 0.00507 & 0.01078 & -0.00604 & 0.00522 \\
\hline & {$[.00036]$} & {$[.00018]$} & {$[.0015]$} & {$[.00025]$} & [.00063] & {$[.00032]$} & {$[.00025]$} \\
\hline \multirow[t]{2}{*}{2412} & 0.00031 & 0.00155 & 0.01080 & 0.00299 & 0.00638 & -0.00191 & 0.00251 \\
\hline & [.00013] & {$[.0001]$} & [.00083] & {$[.00019]$} & [.00043] & {$[.00017]$} & [.00017] \\
\hline \multirow[t]{2}{*}{2413} & 0.00052 & 0.00093 & 0.00208 & 0.00015 & 0.00009 & -0.00070 & 0.00032 \\
\hline & {$[.00012]$} & {$[.000067]$} & [.00038] & {$[.000064]$} & {$[.00016]$} & {$[.00012]$} & {$[.000071]$} \\
\hline \multirow[t]{2}{*}{2421} & 0.00005 & 0.00003 & -0.00001 & -0.00001 & -0.00002 & -0.00001 & 0.00003 \\
\hline & {$[.000024]$} & {$[.000011]$} & [3.8e-06] & {$[3.8 \mathrm{e}-06]$} & {$[.000024]$} & {$[.000019]$} & {$[.000019]$} \\
\hline \multirow[t]{2}{*}{2422} & -0.00040 & 0.00016 & 0.00084 & 0.00007 & 0.00018 & -0.00033 & 0.00002 \\
\hline & {$[.00013]$} & {$[.000031]$} & {$[.00023]$} & [.000039] & {$[.00011]$} & {$[.000079]$} & {$[.00003]$} \\
\hline \multirow[t]{2}{*}{2423} & -0.00001 & 0.00055 & 0.00147 & 0.00014 & 0.00018 & -0.00034 & 0.00005 \\
\hline & {$[.00011]$} & {$[.000056]$} & [.00032] & {$[.00005]$} & [.00013] & {$[.000084]$} & {$[.000036]$} \\
\hline \multirow[t]{2}{*}{2424} & 0.00000 & 0.00002 & 0.00206 & 0.00068 & 0.00173 & -0.00072 & 0.00065 \\
\hline & {$[]$.} & {$[4.2 \mathrm{e}-06]$} & {$[.00035]$} & {$[.000081]$} & {$[.00021]$} & {$[.0001]$} & {$[.000078]$} \\
\hline \multirow[t]{2}{*}{2425} & 0.00000 & 0.00000 & 0.00012 & 0.00000 & 0.00010 & -0.00003 & 0.00002 \\
\hline & {$[]$.} & {$[]$.} & {$[.000086]$} & {$[]$.} & {$[.000049]$} & {$[.00002]$} & {$[.000013]$} \\
\hline \multirow[t]{2}{*}{2426} & -0.00315 & 0.00312 & 0.01561 & 0.00347 & 0.00716 & -0.00520 & 0.00288 \\
\hline & {$[.00036]$} & {$[.00012]$} & [.00098] & {$[.0002]$} & {$[.0005]$} & {$[.00029]$} & [.00018] \\
\hline \multirow[t]{2}{*}{2427} & -0.00008 & 0.00019 & 0.00007 & -0.00002 & 0.00001 & 0.00002 & 0.00003 \\
\hline & {$[.000084]$} & {$[.000029]$} & {$[.000085]$} & {$[.000022]$} & {$[.000078]$} & {$[.000029]$} & {$[.000028]$} \\
\hline \multirow[t]{2}{*}{2428} & 0.00014 & 0.00581 & 0.01469 & 0.00255 & 0.00465 & -0.00166 & 0.00386 \\
\hline & [.00038] & {$[.00017]$} & {$[.001]$} & {$[.00022]$} & [.00053] & {$[.00022]$} & {$[.00023]$} \\
\hline \multirow[t]{2}{*}{2511} & 0.00041 & 0.00759 & 0.02169 & 0.00486 & 0.00746 & -0.00390 & 0.00525 \\
\hline & {$[.00043]$} & {$[.0002]$} & {$[.0012]$} & {$[.00028]$} & {$[.00064]$} & {$[.00029]$} & {$[.00026]$} \\
\hline \multirow[t]{2}{*}{2512} & 0.00010 & 0.00214 & 0.00507 & 0.00040 & 0.00045 & -0.00072 & 0.00063 \\
\hline & {$[.00026]$} & {$[.000099]$} & {$[.00059]$} & {$[.00011]$} & {$[.0003]$} & {$[.00015]$} & {$[.00011]$} \\
\hline \multirow[t]{2}{*}{2522} & 0.00014 & 0.00057 & 0.00088 & 0.00011 & 0.00020 & -0.00021 & 0.00039 \\
\hline & {$[.00011]$} & {$[.000055]$} & {$[.00024]$} & {$[.000053]$} & {$[.00015]$} & {$[.000077]$} & {$[.000073]$} \\
\hline \multirow[t]{2}{*}{2523} & -0.00028 & 0.00231 & 0.00609 & 0.00094 & 0.00036 & -0.00063 & 0.00097 \\
\hline & {$[.00028]$} & {$[.0001]$} & {$[.00066]$} & {$[.00014]$} & [.00029] & {$[.00015]$} & [.00012] \\
\hline \multirow[t]{2}{*}{2531} & 0.00000 & 0.00000 & 0.00012 & 0.00002 & 0.00007 & -0.00001 & 0.00000 \\
\hline & {$[]$.} & [9.5e-07] & {$[.000086]$} & {$[.000014]$} & {$[.000043]$} & {$[.000014]$} & {$[]$.} \\
\hline \multirow[t]{2}{*}{2532} & 0.00005 & 0.00022 & 0.00004 & 0.00003 & 0.00009 & -0.00022 & 0.00007 \\
\hline & {$[.000082]$} & {$[.000032]$} & {$[.000084]$} & {$[.000039]$} & {$[.0001]$} & {$[.00007]$} & {$[.000035]$} \\
\hline \multirow[t]{2}{*}{2542} & 0.00030 & 0.00039 & 0.00106 & 0.00011 & 0.00028 & -0.00105 & 0.00012 \\
\hline & {$[.00011]$} & {$[.000045]$} & [.00028] & {$[.000053]$} & {$[.00016]$} & {$[.00014]$} & {$[.000052]$} \\
\hline \multirow[t]{2}{*}{2543} & -0.00036 & 0.00259 & 0.00325 & 0.00071 & 0.00049 & -0.00040 & 0.00092 \\
\hline & [.00028] & {$[.00013]$} & {$[.0005]$} & {$[.00014]$} & {$[.0003]$} & {$[.00013]$} & [.00012] \\
\hline \multirow[t]{2}{*}{2544} & 0.00022 & 0.00061 & 0.00215 & 0.00040 & 0.00045 & -0.00094 & 0.00046 \\
\hline & {$[.00012]$} & {$[.000051]$} & {$[.00036]$} & {$[.000081]$} & {$[.00018]$} & {$[.00013]$} & {$[.000078]$} \\
\hline 2552 & -0.00433 & -0.00099 & 0.00042 & -0.00011 & -0.00120 & 0.00002 & -0.00003 \\
\hline & [.0004] & {$[.00013]$} & {$[.00024]$} & {$[.000069]$} & {$[.00016]$} & {$[.000097]$} & {$[.000061]$} \\
\hline 2614 & 0.00060 & 0.00043 & 0.00005 & -0.00011 & -0.00051 & 0.00017 & -0.00008 \\
\hline & {$[.000067]$} & {$[.000044]$} & {$[.00011]$} & {$[.000024]$} & {$[.000063]$} & {$[.000023]$} & {$[.000024]$} \\
\hline 2621 & 0.00017 & 0.00712 & 0.01752 & 0.00320 & 0.00573 & -0.00621 & 0.00366 \\
\hline & [.00042] & {$[.00018]$} & {$[.0011]$} & {$[.00023]$} & {$[.00058]$} & {$[.00035]$} & [.00022] \\
\hline 2630 & 0.00005 & 0.00060 & 0.00144 & 0.00050 & 0.00021 & -0.00017 & 0.00052 \\
\hline & {$[.00011]$} & {$[.00007]$} & {$[.00034]$} & {$[.0001]$} & {$[.00014]$} & {$[.000068]$} & {$[.000092]$} \\
\hline 2631 & 0.00013 & 0.00017 & -0.00007 & -0.00003 & -0.00012 & -0.00024 & 0.00006 \\
\hline
\end{tabular}


Table S7. (continued). Oaxaca-Blinder Full Results

\begin{tabular}{|c|c|c|c|c|c|c|c|}
\hline & March & April & May & June & July & August & September \\
\hline & {$[.000069]$} & {$[.000029]$} & {$[.00001]$} & [.000023] & {$[.000067]$} & [.000092] & {$[.000038]$} \\
\hline \multirow[t]{2}{*}{2632} & -0.00001 & 0.00021 & 0.00011 & 0.00003 & 0.00022 & -0.00018 & 0.00013 \\
\hline & {$[.000085]$} & {$[.000031]$} & {$[.000095]$} & {$[.00003]$} & {$[.00011]$} & {$[.000062]$} & {$[.000041]$} \\
\hline \multirow[t]{2}{*}{2634} & 0.00002 & 0.00039 & 0.00203 & 0.00042 & 0.00069 & -0.00034 & 0.00051 \\
\hline & {$[.00012]$} & {$[.000042]$} & {$[.00036]$} & {$[.000085]$} & {$[.00018]$} & {$[.000085]$} & {$[.000081]$} \\
\hline \multirow[t]{2}{*}{2640} & 0.00001 & 0.00001 & 0.00000 & 0.00000 & -0.00001 & 0.00000 & 0.00003 \\
\hline & {$[9.4 \mathrm{e}-06]$} & {$[6.5 \mathrm{e}-06]$} & {$[2.2 \mathrm{e}-06]$} & [6.4e-06] & [8.3e-06] & [2.8e-06] & {$[.000019]$} \\
\hline \multirow[t]{2}{*}{2641} & -0.00001 & 0.00099 & 0.00387 & 0.00020 & 0.00069 & -0.00104 & 0.00078 \\
\hline & {$[.00018]$} & {$[.000065]$} & [.0005] & {$[.00007]$} & [.00023] & {$[.00014]$} & {$[.00011]$} \\
\hline \multirow[t]{2}{*}{2643} & -0.00004 & 0.00074 & 0.00042 & 0.00003 & 0.00029 & -0.00019 & 0.00055 \\
\hline & [.00016] & {$[.000058]$} & {$[.00018]$} & {$[.000051]$} & {$[.00018]$} & {$[.000083]$} & [.00009] \\
\hline \multirow[t]{2}{*}{2644} & 0.00029 & 0.00021 & -0.00007 & -0.00007 & -0.00027 & 0.00009 & -0.00006 \\
\hline & {$[.000047]$} & {$[.000031]$} & {$[.000011]$} & {$[.000011]$} & {$[.00004]$} & {$[.000013]$} & [8.7e-06] \\
\hline \multirow[t]{2}{*}{2651} & 0.00102 & 0.01667 & 0.04262 & 0.00678 & 0.00749 & -0.00591 & 0.00778 \\
\hline & [.00057] & [.0003] & [.0017] & {$[.00034]$} & {$[.00075]$} & {$[.00038]$} & [.00033] \\
\hline \multirow[t]{2}{*}{2652} & -0.00064 & 0.01958 & 0.03968 & 0.00185 & -0.00272 & -0.00512 & 0.00493 \\
\hline & [.00079] & {$[.00029]$} & [.0016] & [.00029] & {$[.00076]$} & {$[.00043]$} & {$[.00031]$} \\
\hline \multirow[t]{2}{*}{2653} & 0.00007 & 0.00032 & 0.00047 & 0.00002 & 0.00006 & -0.00011 & 0.00012 \\
\hline & {$[.000088]$} & {$[.000046]$} & {$[.00018]$} & {$[.000044]$} & {$[.0001]$} & {$[.000056]$} & {$[.000049]$} \\
\hline \multirow[t]{2}{*}{2654} & 0.00002 & 0.00007 & 0.00009 & 0.00000 & 0.00016 & -0.00006 & 0.00009 \\
\hline & {$[.000015]$} & {$[.000023]$} & {$[.000086]$} & [9.8e-06] & {$[.000071]$} & {$[.000033]$} & {$[.000032]$} \\
\hline \multirow[t]{2}{*}{2655} & -0.00006 & 0.00005 & 0.00035 & 0.00004 & 0.00003 & -0.00002 & -0.00003 \\
\hline & {$[.000054]$} & {$[.000015]$} & {$[.00016]$} & {$[.000025]$} & [.000049] & {$[.000023]$} & [8.3e-06] \\
\hline \multirow[t]{2}{*}{2714} & 0.00032 & 0.00054 & 0.00122 & 0.00040 & 0.00011 & -0.00053 & 0.00018 \\
\hline & [.00012] & {$[.00005]$} & {$[.00028]$} & [.00008] & {$[.00016]$} & {$[.00011]$} & {$[.000057]$} \\
\hline \multirow[t]{2}{*}{2716} & -0.00093 & 0.00045 & 0.00036 & 0.00000 & -0.00032 & 0.00010 & 0.00022 \\
\hline & [.00019] & {$[.000046]$} & {$[.00017]$} & {$[.000074]$} & [.000088] & {$[.000036]$} & {$[.000063]$} \\
\hline \multirow[t]{2}{*}{2811} & 0.00004 & 0.00006 & 0.00018 & -0.00002 & -0.00008 & 0.00001 & -0.00002 \\
\hline & {$[.000038]$} & {$[.000017]$} & [.0001] & [9.8e-06] & {$[.000021]$} & {$[.000017]$} & [4.6e-06] \\
\hline \multirow[t]{2}{*}{2812} & 0.00000 & 0.00001 & 0.00115 & 0.00016 & 0.00044 & -0.00029 & 0.00012 \\
\hline & {$[]$.} & {$[2.7 \mathrm{e}-06]$} & {$[.00026]$} & [.000039] & {$[.0001]$} & {$[.000064]$} & {$[.000034]$} \\
\hline \multirow[t]{2}{*}{2813} & -0.00063 & 0.00187 & 0.00428 & 0.00137 & 0.00214 & -0.00091 & 0.00119 \\
\hline & [.00022] & {$[.00011]$} & {$[.00054]$} & {$[.00015]$} & [.00032] & {$[.00014]$} & {$[.00014]$} \\
\hline \multirow[t]{2}{*}{2821} & 0.00000 & 0.00001 & 0.00127 & 0.00016 & 0.00044 & -0.00017 & 0.00006 \\
\hline & {$[]$.} & [2.5e-06] & {$[.00028]$} & {$[.000039]$} & {$[.0001]$} & [.000048] & {$[.000023]$} \\
\hline \multirow[t]{2}{*}{2822} & 0.00004 & 0.00008 & 0.00028 & -0.00001 & 0.00005 & 0.00002 & 0.00006 \\
\hline & {$[.000048]$} & {$[.000019]$} & {$[.00014]$} & {$[.000018]$} & {$[.000071]$} & {$[.000015]$} & {$[.00003]$} \\
\hline \multirow[t]{2}{*}{3111} & 0.00040 & 0.00134 & 0.00165 & 0.00012 & 0.00004 & -0.00146 & 0.00047 \\
\hline & [.0002] & {$[.000076]$} & {$[.00035]$} & {$[.000073]$} & {$[.00021]$} & {$[.00017]$} & {$[.000088]$} \\
\hline \multirow[t]{2}{*}{3113} & -0.00029 & 0.00301 & 0.00686 & 0.00190 & 0.00293 & -0.00027 & 0.00186 \\
\hline & [.00028] & [.00013] & {$[.00069]$} & [.00019] & {$[.0004]$} & {$[.00013]$} & {$[.00017]$} \\
\hline 3115 & 0.00659 & 0.01401 & 0.02615 & 0.00490 & 0.00647 & -0.00921 & 0.00824 \\
\hline & {$[.00057]$} & {$[.00024]$} & [.0013] & {$[.0003]$} & {$[.00078]$} & {$[.00045]$} & [.00033] \\
\hline 3122 & -0.00125 & 0.01792 & 0.03183 & 0.00321 & 0.00572 & -0.01224 & 0.00875 \\
\hline & {$[.00077]$} & {$[.00027]$} & [.0015] & [.00029] & {$[.00086]$} & {$[.00052]$} & {$[.00036]$} \\
\hline 3131 & -0.00040 & 0.00092 & 0.00102 & 0.00017 & 0.00015 & 0.00008 & 0.00038 \\
\hline & {$[.00017]$} & {$[.000069]$} & {$[.00031]$} & {$[.000076]$} & {$[.00017]$} & {$[.000056]$} & {$[.000082]$} \\
\hline 3132 & -0.00398 & 0.00873 & 0.03451 & 0.00400 & 0.01114 & -0.02052 & 0.00620 \\
\hline & [.0007] & {$[.00021]$} & [.0015] & {$[.00027]$} & [.00082] & {$[.00061]$} & [.00029] \\
\hline
\end{tabular}


Table S7. (continued). Oaxaca-Blinder Full Results

\begin{tabular}{|c|c|c|c|c|c|c|c|}
\hline & March & April & May & June & July & August & September \\
\hline \multirow{2}{*}{3142} & 0.00000 & 0.00000 & 0.00006 & 0.00008 & 0.00017 & -0.00004 & 0.00008 \\
\hline & {$[]$.} & {$[]$.} & {$[.000061]$} & {$[.000028]$} & {$[.000065]$} & {$[.000024]$} & {$[.000028]$} \\
\hline \multirow[t]{2}{*}{3211} & 0.00100 & 0.00406 & 0.00452 & 0.00015 & -0.00120 & -0.00167 & 0.00140 \\
\hline & {$[.00035]$} & {$[.00013]$} & {$[.0006]$} & {$[.00013]$} & {$[.00034]$} & {$[.00022]$} & {$[.00016]$} \\
\hline \multirow[t]{2}{*}{3212} & 0.00000 & 0.00009 & 0.01316 & 0.00249 & 0.00703 & -0.00482 & 0.00364 \\
\hline & {$[]$.} & [9.1e-06] & [.00089] & {$[.00016]$} & {$[.00041]$} & {$[.00026]$} & [.00018] \\
\hline \multirow[t]{2}{*}{3221} & 0.00040 & 0.00059 & 0.00018 & -0.00015 & -0.00045 & 0.00006 & 0.00012 \\
\hline & {$[.0001]$} & {$[.000059]$} & {$[.00015]$} & {$[.000021]$} & [.000092] & {$[.000052]$} & {$[.000052]$} \\
\hline \multirow[t]{2}{*}{3222} & 0.00001 & 0.00029 & -0.00009 & 0.00010 & -0.00029 & 0.00010 & -0.00004 \\
\hline & {$[.0001]$} & {$[.000038]$} & {$[.000012]$} & {$[.000068]$} & {$[.000053]$} & {$[.000019]$} & [.00002] \\
\hline \multirow{2}{*}{4111} & -0.00020 & 0.00042 & 0.00416 & 0.00010 & 0.00020 & -0.00174 & 0.00040 \\
\hline & {$[.00024]$} & {$[.000095]$} & {$[.00051]$} & {$[.000077]$} & {$[.00024]$} & [.00019] & {$[.000087]$} \\
\hline \multirow{2}{*}{4201} & -0.00213 & 0.00819 & 0.02144 & 0.00111 & 0.00161 & -0.00820 & 0.00408 \\
\hline & {$[.00059]$} & [.00019] & {$[.0012]$} & {$[.0002]$} & {$[.0006]$} & {$[.00042]$} & {$[.00024]$} \\
\hline \multirow[t]{2}{*}{4211} & 0.00001 & 0.00003 & 0.00465 & 0.00050 & 0.00157 & -0.00128 & 0.00110 \\
\hline & {$[9.4 \mathrm{e}-06]$} & [9.6e-06] & {$[.00053]$} & {$[.00007]$} & [.0002] & [.00013] & {$[.0001]$} \\
\hline \multirow[t]{2}{*}{4213} & 0.00108 & 0.00775 & 0.01146 & 0.00201 & -0.00047 & -0.00169 & 0.00241 \\
\hline & {$[.00047]$} & [.00019] & [.00091] & {$[.00022]$} & {$[.00049]$} & {$[.00026]$} & {$[.00021]$} \\
\hline \multirow[t]{2}{*}{4221} & 0.00638 & 0.02118 & 0.23140 & 0.02453 & 0.07128 & -0.09804 & 0.04147 \\
\hline & [.0012] & [.00043] & {$[.0035]$} & {$[.00058]$} & [.0018] & {$[.0012]$} & [.00065] \\
\hline \multirow[t]{2}{*}{4222} & 0.00006 & 0.00204 & 0.00335 & 0.00023 & 0.00048 & -0.00045 & 0.00045 \\
\hline & [.00023] & {$[.0001]$} & {$[.00049]$} & {$[.000095]$} & {$[.00027]$} & {$[.00013]$} & {$[.000099]$} \\
\hline \multirow[t]{2}{*}{4231} & 0.00238 & 0.00479 & 0.00332 & -0.00004 & -0.00240 & 0.00007 & 0.00058 \\
\hline & {$[.00033]$} & {$[.00015]$} & {$[.00053]$} & {$[.00013]$} & {$[.00033]$} & {$[.00016]$} & {$[.00013]$} \\
\hline \multirow[t]{2}{*}{4999} & 0.00002 & 0.00029 & 0.00193 & 0.00037 & 0.00028 & -0.00050 & -0.00001 \\
\hline & {$[.00011]$} & {$[.000038]$} & {$[.00034]$} & {$[.000078]$} & {$[.00014]$} & {$[.0001]$} & {$[.000033]$} \\
\hline \multirow[t]{2}{*}{5101} & 0.00004 & 0.00065 & 0.00054 & 0.00008 & 0.00001 & -0.00057 & 0.00011 \\
\hline & {$[.00016]$} & {$[.000054]$} & {$[.00022]$} & {$[.000062]$} & {$[.00017]$} & {$[.00012]$} & {$[.000054]$} \\
\hline \multirow[t]{2}{*}{5111} & 0.00105 & -0.00004 & 0.00275 & -0.00035 & -0.00209 & -0.00320 & -0.00036 \\
\hline & {$[.00029]$} & {$[.00013]$} & {$[.00046]$} & {$[.000081]$} & {$[.00022]$} & {$[.00027]$} & {$[.000083]$} \\
\hline \multirow[t]{2}{*}{5112} & -0.00002 & 0.00008 & -0.00003 & -0.00003 & -0.00009 & 0.00003 & -0.00002 \\
\hline & {$[.000057]$} & {$[.000019]$} & {$[6.5 \mathrm{e}-06]$} & {$[6.5 \mathrm{e}-06]$} & {$[.000029]$} & {$[8.2 \mathrm{e}-06]$} & {$[5.3 \mathrm{e}-06]$} \\
\hline \multirow[t]{2}{*}{5113} & -0.00038 & 0.00147 & 0.00133 & 0.00007 & -0.00012 & -0.00047 & 0.00041 \\
\hline & {$[.00022]$} & {$[.000095]$} & {$[.00034]$} & {$[.000075]$} & {$[.00021]$} & {$[.00012]$} & {$[.000089]$} \\
\hline \multirow[t]{2}{*}{5115} & 0.00009 & 0.00016 & 0.00084 & -0.00002 & 0.00019 & -0.00026 & 0.00012 \\
\hline & {$[.000081]$} & {$[.000033]$} & [.00023] & {$[.000026]$} & {$[.00011]$} & {$[.000075]$} & {$[.000043]$} \\
\hline \multirow[t]{2}{*}{5201} & 0.00001 & 0.00020 & -0.00008 & -0.00011 & 0.00016 & -0.00020 & 0.00014 \\
\hline & {$[.000093]$} & {$[.000033]$} & {$[.000024]$} & {$[.000016]$} & {$[.00012]$} & {$[.00007]$} & {$[.000046]$} \\
\hline \multirow[t]{2}{*}{5211} & 0.00018 & 0.00007 & 0.00002 & 0.00012 & -0.00014 & -0.00003 & 0.00004 \\
\hline & {$[.000052]$} & {$[.000028]$} & {$[.00006]$} & {$[.000045]$} & {$[.000053]$} & {$[.000039]$} & {$[.00003]$} \\
\hline 5212 & -0.00227 & 0.00265 & 0.00994 & 0.00203 & 0.00404 & -0.00249 & 0.00167 \\
\hline & {$[.00036]$} & {$[.0001]$} & [.0008] & {$[.00017]$} & {$[.00043]$} & {$[.00022]$} & {$[.00016]$} \\
\hline 5213 & 0.00002 & 0.00005 & 0.00005 & -0.00003 & -0.00001 & 0.00002 & 0.00001 \\
\hline & {$[.000041]$} & {$[.000015]$} & {$[.000065]$} & [9.3e-06] & {$[.000042]$} & [6.6e-06] & {$[.000021]$} \\
\hline 5254 & -0.00004 & 0.00003 & 0.00015 & 0.00007 & 0.00001 & -0.00002 & 0.00007 \\
\hline & {$[.000042]$} & {$[.000012]$} & {$[.00011]$} & {$[.000039]$} & {$[.000037]$} & {$[.000022]$} & {$[.000029]$} \\
\hline 5311 & -0.00001 & 0.00001 & 0.00020 & 0.00007 & 0.00002 & 0.00000 & 0.00007 \\
\hline & {$[.000026]$} & {$[7.9 \mathrm{e}-06]$} & {$[.00011]$} & {$[.000032]$} & {$[.000029]$} & {$[.000015]$} & {$[.000027]$} \\
\hline 5313 & -0.00492 & 0.00460 & 0.01283 & 0.00395 & 0.00458 & -0.00864 & 0.00437 \\
\hline
\end{tabular}


Table S7. (continued). Oaxaca-Blinder Full Results

\begin{tabular}{|c|c|c|c|c|c|c|c|}
\hline & March & April & May & June & July & August & September \\
\hline & {$[.00052]$} & {$[.00014]$} & {$[.00094]$} & {$[.00024]$} & {$[.00054]$} & {$[.00039]$} & {$[.00023]$} \\
\hline \multirow[t]{2}{*}{5314} & -0.00035 & 0.00069 & 0.00334 & 0.00028 & 0.00086 & -0.00051 & 0.00047 \\
\hline & {$[.00015]$} & [.000062] & {$[.00047]$} & {$[.000064]$} & {$[.0002]$} & {$[.0001]$} & {$[.000075]$} \\
\hline \multirow[t]{2}{*}{5411} & 0.00001 & 0.00000 & 0.00000 & 0.00000 & -0.00001 & 0.00000 & 0.00000 \\
\hline & {$[6.7 \mathrm{e}-06]$} & {$[4.6 \mathrm{e}-06]$} & [1.6e-06] & [1.6e-06] & {$[5.8 \mathrm{e}-06]$} & {$[2.0 \mathrm{e}-06]$} & {$[1.3 \mathrm{e}-06]$} \\
\hline \multirow[t]{2}{*}{5413} & 0.00018 & 0.00359 & 0.00736 & 0.00247 & 0.00206 & 0.00027 & 0.00153 \\
\hline & {$[.00022]$} & [.00018] & {$[.00072]$} & {$[.00021]$} & {$[.00036]$} & {$[.000094]$} & {$[.00016]$} \\
\hline \multirow[t]{2}{*}{5999} & 0.01137 & 0.01087 & 0.00235 & 0.00111 & -0.00394 & 0.00240 & 0.00283 \\
\hline & {$[.00034]$} & {$[.00024]$} & {$[.00062]$} & {$[.00024]$} & {$[.00051]$} & {$[.00017]$} & {$[.00025]$} \\
\hline \multirow[t]{2}{*}{6116} & 0.00002 & 0.00001 & 0.00000 & -0.00001 & 0.00004 & -0.00002 & -0.00001 \\
\hline & {$[.000012]$} & {$[7.9 \mathrm{e}-06]$} & {$[2.7 \mathrm{e}-06]$} & {$[4.8 \mathrm{e}-06]$} & {$[.000039]$} & {$[.000025]$} & [6.7e-06] \\
\hline \multirow[t]{2}{*}{7214} & -0.00042 & 0.00094 & 0.00264 & 0.00011 & 0.00106 & -0.00104 & 0.00030 \\
\hline & {$[.00019]$} & {$[.000064]$} & {$[.0004]$} & {$[.000062]$} & {$[.00023]$} & {$[.00014]$} & [.00007] \\
\hline \multirow[t]{2}{*}{8101} & 0.00041 & 0.00265 & 0.00756 & 0.00169 & 0.00166 & -0.00269 & 0.00212 \\
\hline & {$[.00029]$} & {$[.00011]$} & {$[.00073]$} & {$[.00017]$} & {$[.00037]$} & {$[.00023]$} & [.00017] \\
\hline \multirow[t]{2}{*}{8131} & -0.00022 & 0.00005 & 0.00036 & 0.00016 & 0.00035 & -0.00053 & -0.00005 \\
\hline & {$[.000099]$} & {$[.000023]$} & {$[.00016]$} & {$[.000053]$} & {$[.00011]$} & {$[.00011]$} & {$[.000023]$} \\
\hline \multirow[t]{2}{*}{8132} & 0.00001 & 0.00006 & 0.00038 & -0.00004 & 0.00004 & 0.00001 & 0.00000 \\
\hline & {$[.000046]$} & {$[.000016]$} & {$[.00016]$} & {$[.000011]$} & {$[.000062]$} & {$[.000016]$} & {$[.000013]$} \\
\hline \multirow[t]{2}{*}{8133} & -0.00007 & -0.00002 & 0.00015 & 0.00003 & 0.00011 & -0.00011 & 0.00001 \\
\hline & {$[.000047]$} & [.00002] & {$[.000094]$} & {$[.00002]$} & {$[.000059]$} & {$[.000046]$} & {$[.000012]$} \\
\hline \multirow[t]{2}{*}{8135} & 0.00000 & 0.00001 & 0.00061 & 0.00025 & 0.00047 & -0.00021 & 0.00025 \\
\hline & {$[]$.} & {$[2.7 \mathrm{e}-06]$} & {$[.00019]$} & {$[.00005]$} & {$[.00011]$} & {$[.000054]$} & {$[.000049]$} \\
\hline \multirow[t]{2}{*}{8142} & 0.00000 & 0.00000 & 0.00000 & 0.00001 & 0.00000 & -0.00001 & 0.00001 \\
\hline & {$[]$.} & {$[]$.} & {$[]$.} & [9.8e-06] & {$[]$.} & {$[.000014]$} & {$[9.4 \mathrm{e}-06]$} \\
\hline \multirow[t]{2}{*}{8144} & 0.00006 & 0.00003 & 0.00001 & -0.00001 & 0.00002 & -0.00003 & -0.00001 \\
\hline & {$[.000023]$} & {$[.000011]$} & {$[.000026]$} & [3.8e-06] & {$[.000039]$} & {$[.000028]$} & {$[6.4 \mathrm{e}-06]$} \\
\hline \multirow[t]{2}{*}{8153} & 0.00001 & 0.00001 & 0.00000 & 0.00000 & -0.00001 & 0.00000 & 0.00000 \\
\hline & [9.4e-06] & {$[6.5 \mathrm{e}-06]$} & {$[2.2 \mathrm{e}-06]$} & {$[2.2 \mathrm{e}-06]$} & {$[8.3 \mathrm{e}-06]$} & {$[2.8 \mathrm{e}-06]$} & {$[1.8 \mathrm{e}-06]$} \\
\hline \multirow[t]{2}{*}{8154} & 0.00001 & 0.00001 & 0.00000 & 0.00000 & -0.00001 & 0.00000 & 0.00000 \\
\hline & [9.4e-06] & {$[6.5 \mathrm{e}-06]$} & {$[2.2 \mathrm{e}-06]$} & {$[2.2 \mathrm{e}-06]$} & {$[8.3 \mathrm{e}-06]$} & {$[2.8 \mathrm{e}-06]$} & [4.6e-06] \\
\hline \multirow[t]{2}{*}{8161} & 0.00009 & 0.00010 & 0.00073 & -0.00003 & 0.00026 & 0.00003 & 0.00009 \\
\hline & {$[.000047]$} & [.00002] & [.00023] & {$[.000013]$} & {$[.0001]$} & {$[.000024]$} & {$[.000032]$} \\
\hline \multirow[t]{2}{*}{8211} & 0.00051 & 0.00051 & 0.00061 & 0.00026 & -0.00006 & -0.00042 & 0.00016 \\
\hline & {$[.000063]$} & {$[.000051]$} & [.00023] & {$[.000069]$} & {$[.00011]$} & {$[.00009]$} & {$[.00005]$} \\
\hline \multirow[t]{2}{*}{8323} & 0.00000 & 0.00000 & 0.00036 & 0.00004 & 0.00022 & -0.00007 & 0.00004 \\
\hline & {$[]$.} & [1.3e-06] & {$[.00015]$} & {$[.00002]$} & {$[.000074]$} & {$[.000031]$} & {$[.000019]$} \\
\hline \multirow[t]{2}{*}{8341} & -0.00016 & 0.00036 & 0.00257 & 0.00037 & 0.00149 & -0.00046 & 0.00055 \\
\hline & {$[.00009]$} & [.000049] & [.00039] & {$[.00007]$} & {$[.00021]$} & {$[.000084]$} & {$[.000076]$} \\
\hline \multirow[t]{2}{*}{8342} & 0.00000 & 0.00000 & 0.00297 & 0.00011 & 0.00032 & -0.00014 & 0.00008 \\
\hline & [.] & [1.3e-06] & [.00042] & {$[.000033]$} & {$[.000089]$} & {$[.000044]$} & {$[.000027]$} \\
\hline 9231 & -0.00167 & 0.00197 & 0.00790 & 0.00115 & 0.00415 & -0.00496 & 0.00299 \\
\hline & {$[.00035]$} & {$[.0001]$} & [.00072] & {$[.00014]$} & {$[.00044]$} & {$[.0003]$} & [.00019] \\
\hline 9232 & -0.00483 & 0.00386 & 0.00960 & 0.00473 & 0.00649 & -0.01598 & 0.00668 \\
\hline & {$[.00046]$} & [.00012] & {$[.00078]$} & {$[.00023]$} & {$[.00052]$} & {$[.00049]$} & {$[.00026]$} \\
\hline 9233 & -0.00014 & 0.00008 & 0.00032 & 0.00003 & 0.00029 & -0.00017 & 0.00005 \\
\hline & {$[.000086]$} & [.000019] & {$[.00015]$} & {$[.000026]$} & {$[.0001]$} & {$[.000058]$} & [.000029] \\
\hline 9235 & -0.00002 & 0.00002 & -0.00001 & -0.00001 & 0.00000 & 0.00000 & 0.00001 \\
\hline & {$[.000047]$} & {$[.00001]$} & [3.5e-06] & {$[3.5 \mathrm{e}-06]$} & [.000029] & {$[.000015]$} & {$[.000012]$} \\
\hline
\end{tabular}


Table S7. (continued). Oaxaca-Blinder Full Results

\begin{tabular}{cccccccc} 
& March & April & May & June & July & August & September \\
\hline \multirow{2}{*}{9236} & -0.00027 & 0.00067 & 0.00127 & 0.00015 & 0.00046 & -0.00024 & 0.00035 \\
& {$[.00014]$} & {$[.000069]$} & {$[.00029]$} & {$[.000053]$} & {$[.00016]$} & {$[.000073]$} & {$[.000067]$} \\
9239 & -0.00054 & 0.00401 & 0.01271 & 0.00267 & 0.00504 & -0.00100 & 0.00276 \\
& {$[.00037]$} & {$[.00013]$} & {$[.00093]$} & {$[.00021]$} & {$[.00052]$} & {$[.00019]$} & {$[.0002]$} \\
9331 & -0.00583 & 0.00674 & 0.03693 & 0.00300 & 0.00955 & -0.02092 & 0.00852 \\
& {$[.00069]$} & {$[.00019]$} & {$[.0015]$} & {$[.00025]$} & {$[.00077]$} & {$[.00061]$} & {$[.00032]$} \\
9411 & -0.00752 & 0.00124 & 0.00345 & -0.00010 & -0.00115 & -0.00339 & 0.00026 \\
& {$[.00049]$} & {$[.00009]$} & {$[.00049]$} & {$[.000084]$} & {$[.00023]$} & {$[.00026]$} & {$[.000097]$} \\
9512 & -0.00058 & 0.01715 & 0.04070 & 0.00430 & 0.00695 & -0.01458 & 0.00756 \\
& {$[.00076]$} & {$[.00027]$} & {$[.0016]$} & {$[.00031]$} & {$[.00086]$} & {$[.00056]$} & {$[.00033]$} \\
9521 & -0.00012 & 0.00069 & 0.00208 & 0.00062 & 0.00049 & -0.00019 & 0.00058 \\
& {$[.00014]$} & {$[.00006]$} & {$[.00037]$} & {$[.0001]$} & {$[.00018]$} & {$[.000075]$} & {$[.00009]$} \\
9601 & -0.00045 & 0.00006 & -0.00002 & -0.00002 & -0.00008 & 0.00003 & -0.00002 \\
& {$[.00011]$} & {$[.000017]$} & {$[5.9 \mathrm{e}-06]$} & {$[5.9 \mathrm{e}-06]$} & {$[.000022]$} & {$[7.4 \mathrm{e}-06]$} & {$[4.8 \mathrm{e}-06]$} \\
9621 & 0.00000 & 0.00000 & 0.00091 & 0.00034 & 0.00096 & -0.00026 & 0.00021 \\
& {$[]$.} & {$[1.9 \mathrm{e}-06]$} & {$[.00023]$} & {$[.000058]$} & {$[.00015]$} & {$[.000061]$} & {$[.000044]$} \\
9622 & -0.00073 & 0.00039 & 0.00177 & 0.00012 & 0.00014 & -0.00528 & 0.00061 \\
& {$[.00029]$} & {$[.000066]$} & {$[.00034]$} & {$[.000086]$} & {$[.00024]$} & {$[.0003]$} & {$[.00011]$} \\
9641 & -0.00016 & 0.00012 & -0.00004 & -0.00003 & -0.00004 & -0.00009 & -0.00004 \\
& {$[.000089]$} & {$[.000023]$} & {$[7.5 \mathrm{e}-06]$} & {$[.000011]$} & {$[.000079]$} & {$[.00005]$} & {$[.000011]$} \\
\multirow{4}{*}{9622} & -0.00029 & 0.00148 & 0.00553 & 0.00103 & 0.00090 & -0.00181 & 0.00150 \\
& {$[.00026]$} & {$[.000082]$} & {$[.00061]$} & {$[.00013]$} & {$[.00029]$} & {$[.00019]$} & {$[.00014]$} \\
\multirow{4}{*}{ Constant } & 0.04979 & -0.52971 & -1.16506 & -0.17111 & -0.26385 & 0.34841 & -0.28249 \\
& {$[]$.} & {$[]$.} & {$[]$.} & {$[]$.} & {$[]$.} & {$[]$.} & {$[]$.} \\
\hline
\end{tabular}

